\title{
WestVirginiaUniversity
}

THE RESEARCH REPOSITORY @ WVU

Graduate Theses, Dissertations, and Problem Reports

2018

\section{Wintering American Black Duck Ecology of Central Appalachia}

Sara E. Yannuzzi

West Virginia University, sey0001@mix.wvu.edu

Follow this and additional works at: https://researchrepository.wvu.edu/etd

Part of the Natural Resources and Conservation Commons, Natural Resources Management and Policy Commons, and the Ornithology Commons

\section{Recommended Citation}

Yannuzzi, Sara E., "Wintering American Black Duck Ecology of Central Appalachia" (2018). Graduate Theses, Dissertations, and Problem Reports. 3735.

https://researchrepository.wvu.edu/etd/3735

This Thesis is protected by copyright and/or related rights. It has been brought to you by the The Research Repository @ WVU with permission from the rights-holder(s). You are free to use this Thesis in any way that is permitted by the copyright and related rights legislation that applies to your use. For other uses you must obtain permission from the rights-holder(s) directly, unless additional rights are indicated by a Creative Commons license in the record and/ or on the work itself. This Thesis has been accepted for inclusion in WVU Graduate Theses, Dissertations, and Problem Reports collection by an authorized administrator of The Research Repository @ WVU. For more information, please contact researchrepository@mail.wvu.edu. 


\section{Sara Yannuzzi}

Thesis submitted to the Davis College of Agriculture, Natural Resources, and Design

At West Virginia University

In partial fulfillment of the requirements for the degree of

Master of Science

In

Wildlife and Fisheries Resources

James T. Anderson, Ph.D., Chair

Michael L. Peters, M.S.

Christopher T. Rota, Ph.D.

Division of Forestry and Natural Resources

Morgantown, West Virginia

2018

Keywords: American Black Duck, Mallards, Wetlands, Wintering Waterfowl

Copyright 2018 Sara Yannuzzi 


\section{ABSTRACT \\ WINTERING AMERICAN BLACK DUCK ECOLOGY OF CENTRAL APPALACHIA}

\section{Sara Yannuzzi}

The American black duck (Anas rubripes) is a species of dabbling duck found only in the northeastern part of North America, and widely hunted until its decline. Since the 1950s, the total population has decreased by 53\%. Habitat degradation and decline of wintering and breeding wetlands, historic overharvest, and interactions with the mallard (A. platyrhynchos) are attributed as some of the main causes of the black duck population's decrease. Many policies and taxa- and habitat-specific joint ventures have since been created to aid in studying and improving North American wetlands and black duck populations throughout both their breeding and wintering range. However, limited research has been performed in the western reaches of the black duck's wintering range, where $2.8-8.9 \%$ of the wintering population resides in habitats that are very different than the Atlantic core range of the black duck. As such, we examined wetland biomass and energy availability throughout the region using moist-soil seed production sampling and benthic core sampling, finding riverine systems provided the highest energy to wintering black ducks of all wetland systems, unmanaged wetlands provided the most energy of all management schemes, and modified wetlands provided the greatest energy of all levels of naturalness. Ultimately, we found Central Appalachia could provide for 1,077,805 - 1,916,452 black ducks throughout the winter. Additionally, we calculated time-activity budgets for wintering black ducks from behavioral observations and estimated daily energy expenditure using both a simpleand a complex-cost of thermoregulation component. We found that swimming was the most observed behavior overall, but that behavior varied among wetland systems, management schemes, levels of naturalness, and year. From this, we estimated daily energy expenditure with a complex-cost of thermoregulation of a wintering black duck in Central Appalachia to be $1,542.95 \mathrm{~kJ} / \mathrm{bird} /$ day, which was 2.25 times higher than the estimation with a simple-cost of thermoregulation component. Lastly, we used single-season occupancy models and $\mathrm{N}$-mixture models to determine drivers of black duck and mallard occupancy and abundances in the region. We determined that black duck occupancy was higher in passively managed wetlands, palustrine systems, and modified wetlands, and lower in the second year of the study. Black duck abundance decreased in the second year of the study and was higher in riverine and palustrine systems, modified wetlands, passively managed wetlands, and when beavers were present, as well. Meanwhile, mallard occupancy was positively associated with increasing surrounding developed land within $200 \mathrm{~m}$ of survey points. Mallard abundance was positively associated with actively managed wetlands, palustrine systems, created wetlands, and privately-owned wetlands. Both mallards and black ducks were positively associated with many surrounding land use types. From this research, we recommend that future research incorporates the complex-cost of thermoregulation component into energy expenditure calculations to acquire more refined estimates of duck-use days. We also recommend that managers follow strict water-level 
manipulation schedules to improve seed biomass in wetlands, focus on providing nearby diverse wetland complexes of varying management schemes, and incorporating passive management at currently unmanaged riverine wetlands. 


\section{ACKNOWLEDGMENTS}

I thank the U.S. Fish and Wildlife Black Duck Joint Venture, the Pennsylvania Game Commission, the West Virginia Division of Natural Resources, and West Virginia University for their financial and logistical support of this research. I also thank the private landowners, Pennsylvania Department of Conservation and Natural Resources, and West Virginia State Parks and Forests for allowing me access to perform my research at all hours of the day. I also thank my thesis advisor Dr. Anderson and committee members Dr. Rota and Mr. Peters for their support and guidance over the past two years.

To the numerous lab technicians who stayed attentive while helping with endless core sorting and sample identification, you have my sincere gratitude: Zak Dienes, Hannah Warner, Lauren Stollings, Mary Evers, Saahira Cua, Jonathan Gordon, Cassidy Rausch, and Lindsay Leightner. I thank the bounty of surveyors, Scott Carr, Craig McDougal, Jeremy Stempka, Bruce Ellis, Kevin Jacobs, Dustin Dowler, Thomas Pratt, Tammy Shreve, Jeff McCrady, Thomas Hardman, Josh Allison, and John Sammons, for braving the cold and snow to count waterfowl in support of the project. To Melissa Petschauer, who not only helped in all aspects of the field and lab work, but also kept me awake during late survey nights by telling me stories and kept my spirits high not only when she was working with me, but long after she left, thank you for your enduring friendship and support. I thank Lizzi Bonczek who has always had faith in me on the days when I've lacked it and who has also navigated the ups and downs on our waterfowlfocused paths since 2012 with me, Alissa Gulette for always lending an ear, shoulder, some advice, or motivation, Brett Skelly for his patience and enthusiasm when helping me with statistics, David Howard for reminding me to enjoy the ride, and my family, friends, and fellow graduate students for their advice, friendship, and steadfast encouragement. Not to be forgotten, I thank my dog Rowen, for his constant companionship and for forcing me to come up for air once in a while. Lastly, I thank Sara Crowell and my parents, for without them, I may never have discovered my love of waterfowl and science that got me here today. 


\section{TABLE OF CONTENTS}

\section{Table of Contents}

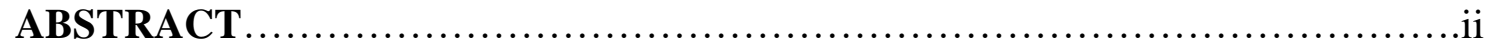

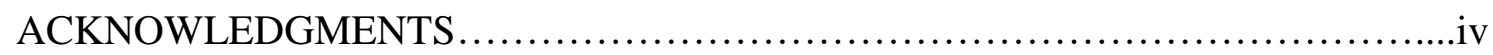

Table of Contents....................................................................

LIST OF FIGURES ........................................................

LIST OF TABLES ........................................................viii

Chapter 1: Wintering American Black Duck Carrying Capacity in Central Appalachia

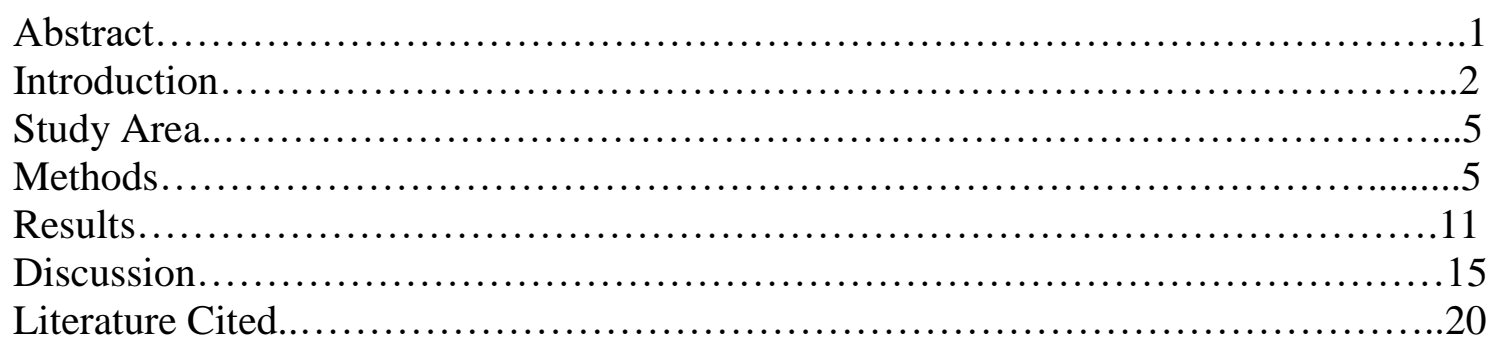

Chapter 2: Daily Energy Expenditure and Activities of Wintering American Black

Ducks............................................................................. 37

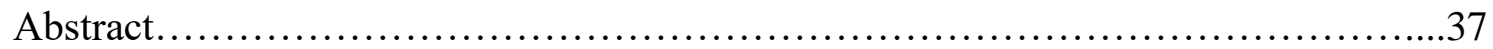

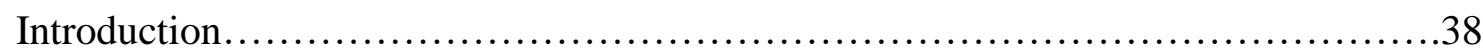

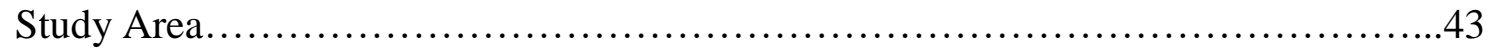

Methods..................................................................... 44

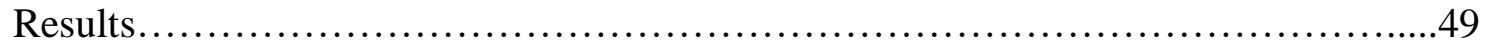

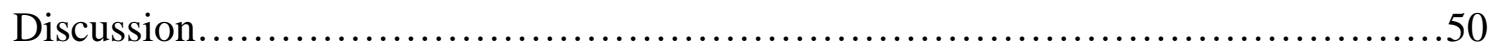

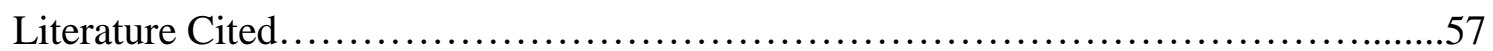

Chapter 3: Wintering American Black Duck Habitat Use on the Appalachian Plateau

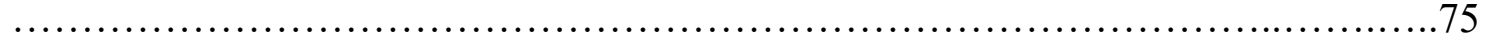

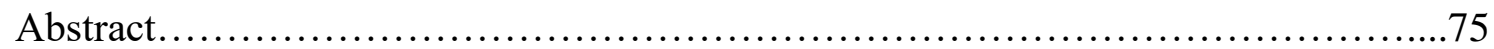

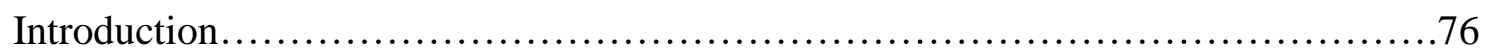

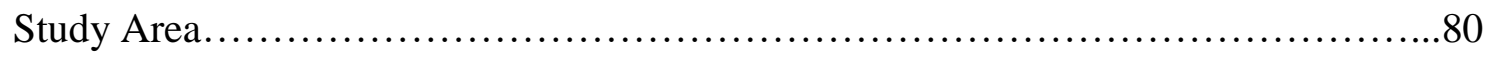

Methods.................................................................... 81

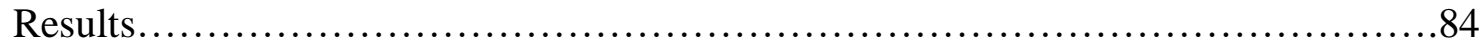

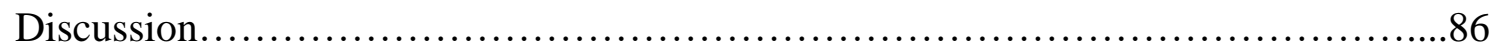

Literature Cited ............................................................. 92

Appendix A. Published TME Values of Black Duck Foods.......................111

Appendix B. Univariate Models........................................... 119

Appendix C. System-Associated Moist-Soil Seed Biomass Estimation..................120

Appendix D. Level of Naturalness-Associated Moist-Soil Seed Biomass Estimations

Appendix E. Management Scheme-Associated Moist-Soil Seed Biomass Estimations

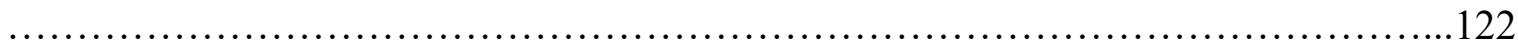

Appendix F. System-Associated Benthic Core Biomass Estimations...............123 
Appendix G. Level of Naturalness-Associated Benthic Core Biomass Estimations....124

Appendix H. Management Scheme-Associated Benthic Core Biomass Estimations ..125

Appendix I. Average Monthly Temperatures .................................... 126

Appendix J. Activity-Specific Multipliers ....................................127

Appendix K. Wetland System-Associated Behavioral Proportions ..................128

Appendix L. Level of Naturalness-Associated Behavioral Proportions ................129

Appendix M. Wetland Management Scheme-Associated Behavioral Proportions......130

Appendix N. Year-Associated Behavioral Proportions..........................................131

Appendix O. Daily Energy Expenditure Values of American Black Ducks.............132

Appendix P. Daily Energy Expenditure Values With Other RMR Values..............133

Appendix Q. Wind Speed Codes............................................... 134

Appendix R. Sky Condition Codes............................................. 135 


\section{LIST OF FIGURES}

Figure 2-1. Study area and survey sites used for collecting time activity budgets of wintering American black ducks in western Pennsylvania and north-central West Virginia, November March 2015 - 2016 and 2016 - 2017

Figure 3-1. Occupancy probability of black ducks across years (A), wetland systems (B), and management schemes (C), and level of naturalness (D) from wintering waterfowl surveys in West Virginia and Pennsylvania, USA, November to March 2015-2016 and 2016-2017. Within the plots, the dots represent mean occupancy and the lines are $95 \%$ confidence intervals.

Figure 3-2. Occupancy probability of mallards in association with surrounding developed land use from wintering waterfowl surveys in West Virginia and Pennsylvania, USA, November to March 2015-2016 and 2016-2017

Figure 3-3. Abundance predictions, estimated number of individuals, from wintering waterfowl counts of black ducks in relation to year (A), wetland size (B), wetland system (C), level of naturalness $(\mathrm{D})$, management scheme $(\mathrm{E})$, and beaver presence $(\mathrm{F})$ from wintering waterfowl surveys in West Virginia and Pennsylvania, USA, November to March 2015-2016 and 20162017. The dots represent mean abundance and the bars are $95 \%$ confidence intervals.

Figure 3-4. Abundance predictions, estimated number of individuals, from wintering waterfowl counts of black ducks in relation to barren land (A), forest land (B), herbaceous land $(C)$, hay pasture land (D), cultivated cropland (E), and wetland (F) within $200 \mathrm{~m}$ of a survey point from wintering waterfowl surveys in West Virginia and Pennsylvania, USA, November to March 2015-2016 and 2016-2017.

Figure 3-5. Abundance predictions, estimated number of individuals, from wintering waterfowl counts of mallards in relation to wetland size (A), wetland system (B), and developed land (C), open water (D), barren land (E), and forest land (F) within $200 \mathrm{~m}$ of a survey point from wintering waterfowl surveys in West Virginia and Pennsylvania, USA, November to March 2015-2016 and 2016-2017.

Figure 3-6. Abundance predictions, estimated number of individuals, from wintering waterfowl counts of mallards in relation to hay pasture land (A), cultivated cropland (B), and wetland (C) within $200 \mathrm{~m}$, level of naturalness (D), management scheme (E), and land ownership (F) of a survey point from wintering waterfowl surveys in West Virginia and Pennsylvania, USA, November to March 2015-2016 and 2016-2017. 


\section{LIST OF TABLES}

Table 1-1. Criteria for levels of wetland naturalness and wetland management schemes used for American black duck food and energy availability sampling in western Pennsylvania and northcentral West Virginia, March - April, August - October, and November - December 2017.

Table 1-2. Dominant plant species used to calculate predictive models in order to determine available biomass at wetlands. Seeds were collected from wetlands following methods from Gray et al. (1999a) in north-central West Virginia and western Pennsylvania in August-October 2017.

Table 1-3. Estimated food availability (kg/ha) and energy (kcal/ha) calculated from moist-soil seed production sampling for wintering American black ducks in north-central West Virginia and western Pennsylvania taken in March - April and November - December 2017.

Table 1-4. Estimated landscape-level duck use days (DUDs) and energy (kcal) from moist soil seed production sampling and benthic core sampling for wintering American black ducks in north-central West Virginia and western Pennsylvania taken in March - April and November December 2017.

Table 1-5. Estimated landscape-level duck use days (DUDs) and energy (kcal) from moist soil seed production sampling and benthic core sampling for wintering American black ducks in north-central West Virginia and western Pennsylvania taken in March - April and November December 2017. $1 \mathrm{~m}, 5 \mathrm{~m}$, and $10 \mathrm{~m}$ buffers of lacustrine and riverine system area are applied to estimates. Overall estimates incorporate unbuffered, total area of palustrine wetlands.

Table 1-6. Estimated food availability ( $\mathrm{kg} / \mathrm{ha}$ ) and energy ( $\mathrm{kcal} / \mathrm{ha})$ of combined seeds and macroinvertebrates calculated from benthic core sampling for wintering American black ducks in north-central West Virginia and western Pennsylvania taken in Mar - April and Nov - Dec 2017.

Table 1-7. Estimated seed biomass ( $\mathrm{kg} / \mathrm{ha}$ ) and energy ( $\mathrm{kcal} / \mathrm{ha})$ calculated from benthic core sampling for wintering American black ducks in north-central West Virginia and western Pennsylvania taken in March - April and November - December 2017.

Table 1-8. Estimated macroinvertebrate biomass (kg/ha) and energy (kcal/ha) calculated from benthic core sampling for wintering American black ducks in north-central West Virginia and 
western Pennsylvania taken in March - April and November - December 2017

Table 2-1. Criteria for levels of wetland naturalness and wetland management schemes used for time activity budgets of wintering American black ducks in western Pennsylvania and northcentral West Virginia, November - March 2015 - 2016 and 2016 - 2017 (USEPA 2016).

Table 2-2. Waterfowl behaviors used for time activity budgets of wintering American black ducks in western Pennsylvania and north-central West Virginia, November - March 2015 - 2016 and $2016-2017$.

Table 2-3. Average predicted probabilities and standard errors from multinomial models of American black duck diurnal time-activity budgets among wetland systems in western Pennsylvania and north-central West Virginia in November - March of 2015 - 2016 and 2016 2017.

Table 2-4. Average predicted probabilities and standard errors from multinomial models of American black duck diurnal time-activity budgets among levels of wetland naturalness in western Pennsylvania and north-central West Virginia in November - March of 2015 - 2016 and $2016-2017$.

Table 2-5. Average predicted probabilities and standard errors from multinomial models of American black duck diurnal time-activity budgets by wetland management schemes in western Pennsylvania and north-central West Virginia in November - March of 2015 - 2016 and 2016 2017.

Table 2-6. Average predicted probabilities and standard errors from multinomial models of American black duck diurnal time-activity budgets between survey years in western Pennsylvania and north-central West Virginia in November - March of 2015 - 2016 and 2016 2017.

Table 2-7. Average daily energy expenditure calculated using a complex cost of thermoregulation component of American black ducks by wetland system, management schemes, level of naturalness, and year in western Pennsylvania and north-central West Virginia in November March of $2015-2016$ and 2016-2017. Means are not significantly different from each other within each group $(P>0.05)$.

Table 3-1. Criteria for levels of wetland naturalness and wetland management schemes during wintering waterfowl and black duck surveys between November and March $2015-2016$ and 2016 - 2017 in western Pennsylvania and north-central West Virginia, USA (USEPA 2016). 
Table 3-2. List of single-season occupancy models used to determine the top model for black duck (ABDU) and mallard (MALL) occupancy in November and March 2015-2016 and 20162017 in western Pennsylvania and north-central West Virginia, USA. Models include land ownership (LO), open water within $200 \mathrm{~m}$ (OW), developed land within $200 \mathrm{~m}$ (DE), barren land within $200 \mathrm{~m}$ (BL), forested land within $200 \mathrm{~m}$ (FO), herbaceous land within $200 \mathrm{~m}$ (HE), pasture/hay within $200 \mathrm{~m}(\mathrm{PH})$, cultivated crop land within $200 \mathrm{~m}(\mathrm{CC})$, and wetland within 200 $\mathrm{m}(\mathrm{WE})$.

Table 3-3. List of N-mixture models used to determine the top model for black duck (ABDU) and mallard (MALL) abundances in November and March 2015-2016 and 2016-2017 in western Pennsylvania and north-central West Virginia, USA. Models include land ownership (LO), open water within $200 \mathrm{~m}$ (OW), developed land within $200 \mathrm{~m}$ (DE), barren land within $200 \mathrm{~m}$ (BL), forested land within $200 \mathrm{~m}$ (FO), herbaceous land within $200 \mathrm{~m}$ (HE), pasture/hay within $200 \mathrm{~m}(\mathrm{PH})$, cultivated crop land within $200 \mathrm{~m}$ (CC), and wetland within $200 \mathrm{~m}$ (WE). 


\section{Chapter 1: Wintering American Black Duck Carrying Capacity in Central Appalachia}

ABSTRACT The American black duck (Anas rubripes) population, a species unique to the northeastern part of North America, has decreased by 53\% since the 1950 s. Wintering and breeding wetland habitat degradation and decline is attributed as one of the main causes of the black duck population deterioration, along with historic overharvest and interactions with the mallard (Anas platyrhynchos). As such, numerous policies and joint ventures have been established to study and improve North America's wetland habitat and black duck populations throughout both their breeding and wintering range. Winter food biomass at these wetlands is an important indicator for both wetland and black duck health, as it can have implications on winter survival, and success during the migratory and breeding period. As limited research has explored food availability in the western extent of the black duck's wintering range on the Appalachian Plateau, we aimed to estimate food biomass and carrying capacity in north-central West Virginia and western Pennsylvania for wintering black ducks. We performed moist-soil seed production dot grid sampling and took benthic core samples from wetlands across the study area. We determined that dot grid sampling predictive equations could be applied to 14 of 20 seeding plant species in the region. Through benthic core sampling, we calculated 228,494,600 - 406,287,916 DUDs throughout the study area. We found that biomass and energy varied by wetland system, level of naturalness, and management scheme. Riverine systems contained the greatest energy and lacustrine the greatest biomass, and modified wetlands and unmanaged wetlands contained the greatest energy and biomass. Last, moist-soil seed production sampling provided a better, higher estimate of seed biomass than benthic core sampling, but does not capture invertebrate biomass, and as such, we recommend the methods be used in conjunction in the future. As seed biomass was lower than macroinvertebrate biomass, we suggest managers focus on manipulating 
water levels to encourage seed germination and ultimately increase food availability for wintering waterfowl.

KEYWORDS Anas rubripes, biomass, duck use days, invertebrates, Pennsylvania, seeds, waterfowl, wetland management, West Virginia American black ducks (Anas rubripes; hereafter, black duck) have been documented as a waterfowl species in decline since the 1950s, as evidenced by the Midwinter Waterfowl Inventory (MWI) which was used to document wintering waterfowl populations and habitat in the United States and Ontario between 1955 and 2015 (Conroy et al. 2002). Black ducks, a species found only in northeastern North America and widely hunted until its decline, showed a population decrease in Midwinter Waterfowl Inventory data from 750,000 to 288,800 birds between 1955 and 2014 (USFWS 2014). Historic overharvest, competition and hybridization with the mallard (A. platyrhynchos), and loss in quality and amount of both breeding and wintering habitat have been implicated in their decline (Blandin 1992, Francis et al. 1998, Conroy et al. 2002).

Synonymous to the decline of the black duck, North American wetlands lost $50 \%$ of their total area due to destruction from agricultural, silvicultural, and rural and urban development (Dahl 2011). Approximately 24\% of wetlands in West Virginia and 56\% of wetlands in Pennsylvania were lost between the 1780s and the 1980s (Dahl 1990). These states, particularly within the Appalachian Plateau, are important to non-breeding black ducks during both the migration and wintering period, with $2.8-8.9 \%$ of the overall population stopping there over winter (National Audubon Society 2010).

With policies setting the pace for the improvement of wetland status in the past few decades, wetland area has improved, but black duck numbers have not (1.4 ha/observed black 
duck in 1954 to 2.6 ha/observed black duck in 1980; Morton et al. 1989). This calls into question if black duck declines are tied to the quality of existing wetland habitat (Morton et al. 1989). Seed biomass is considered an indicator of wetland health (Fennessy et al. 2002). Past research has quantified food abundance in wetlands in the Atlantic Coast core range of the black duck (Plattner et al. 2010, Cramer et al. 2012, Livolsi 2015, Fino et al. 2017), leaving a dearth of knowledge in the western reaches of the black duck's range. In New Jersey, Cramer et al. (2012) quantified total black duck food biomass between $467-4,400 \mathrm{~kg} / \mathrm{ha}$ dependent upon habitat type, Fino et al. (2017) estimated total food biomass in mid-Atlantic forested wetlands at $57.69 \pm$ 12.16 kg/ha, and Plattner et al. (2010) estimated Long Island, NY to contain $217 \pm 41 \mathrm{~kg} / \mathrm{ha}$. Core range biomass estimates are mostly in the realm of or lower than prior estimates of moistsoil seed density approximations, which range from $400-3,155 \mathrm{~kg} / \mathrm{ha}$ and is a habitat type where some dabbling ducks obtain most of their food (Fredrickson and Taylor 1982, Reinecke et al. 1989, Anderson and Smith 1999, Naylor 2002, Penny 2003, Bowyer et al. 2005, Plattner et al. 2010).

Furthermore, seed and invertebrate biomass in aquatic habitats can fluctuate in response to wetland management scheme, level of wetland naturalness, and type of wetland system. Rivers diminish seed densities in adjoining wetlands due to dispersal, and created wetlands hold concentrated invertebrate densities in the water column as opposed to natural wetlands, which contain them in the benthic layer (Balcombe et al. 2005, Vonbank et al. 2016). Functionally, created wetlands in Pennsylvania were primarily inundated year-round with open water, which does not meet conditions conducive to seed germination and invertebrate hatches from water level fluctuations, whether naturally occurring or from an active management scheme (Fredrickson and Taylor 1982, Anderson and Smith 2000, Cole and Brooks 2000). In the mid- 
Atlantic, mudflat habitat types provided higher energy and biomass densities than freshwater, salt marsh, or subtidal habitats (Plattner et al. 2010, Cramer et al. 2012). Winter food availability is vital to supplying necessary nutrients to waterfowl during spring migration and for some species, during the breeding season (Batt et al. 1992). Furthermore, food intake of the black duck is drastically different among interior, tidal (i.e., tidally influenced portions of rivers with low salinity), and coastal habitats (i.e., tidally influenced open bays and marshes with high salinity; Mendall 1949). Grasses like wild rice (Zizania aquatica) make up over half of the tidal black duck diet, while animal foods comprise over half of coastal black duck diets, and interior black ducks rely upon a diverse selection of both plant and animal matter in the fall (Mendall 1949). As such, applying former estimates of coastal and tidal food availability to interior freshwater wetlands holds the potential for error in our assumptions, leading to improper management applications.

Our objective was to estimate food supply and carrying capacity of inland freshwater wetlands for wintering black ducks in western Pennsylvania and north-central West Virginia, USA. Furthermore, we aimed to determine the differences in biomass provided by different wetland management schemes, levels of wetland naturalness, and wetland systems. We hypothesize that wintering biomass and energy estimates will be lower in our study area than found in previous coastal and tidal research due to freshwater habitats typically supplying low biomass and energy levels in previous literature. Furthermore, we also hypothesize based on previous literature that food availability will be lower in unmanaged wetlands than actively or passively managed wetlands, lower in riverine systems than lacustrine or palustrine systems, and lower in created wetlands than in natural or modified wetlands. From this information, we aim to 
provide guidance for waterfowl managers, biologists, and policy makers when determining how to best conserve and manage wetlands for wintering black ducks.

\section{STUDY AREA}

We conducted our study in western Pennsylvania (2,258,654 ha) and north-central West Virginia $(1,220,646 \mathrm{ha})$. We classified wetlands in the study area into 6 freshwater categories from National Wetlands Inventory (NWI) data (USFWS 2015). Freshwater aquatic systems in the study area were divided into: Freshwater Emergent, Freshwater Forested/Scrub-Shrub, Freshwater Pond, Riverine, Lake, and Other (USFWS 2015). Palustrine systems were the most abundant (83,091.67 ha), followed by riverine systems (54,565.38 ha), and lacustrine systems (26,322.89 ha). The study area consists of 2 physiographic divisions, the Appalachian Plateau Division (201 - $978 \mathrm{~m})$ and the Central Lowlands Division $(173-305 \mathrm{~m})$ at the northernmost end of the study area in Erie County, PA. The climate is temperate with extreme local winter spikes. Average local temperatures range from -5 to $21.5^{\circ}$ year-round, with mean local snowfall accumulations from $51-256 \mathrm{~cm}$ (PSU 2016, NCDC 2018, NWS 2018).

\section{METHODS}

Wetland Site Selection We subsampled 21 wetlands by benthic core sampling for seed and macroinvertebrate biomass, and an additional 16 wetlands $(\mathrm{n}=37)$ wetlands for moist-soil seed production to determine peak seeding biomass. We drew these wetlands from a selection of waterbodies originally chosen through a stratified random sample for conducting black duck surveys. The original stratified random sample was based on latitude, in which there were 10 latitudinal stratifications, with 5 in PA and 5 in WV. This stratified random sample and our subsample from it contained wetlands that were selected using NWI data to ensure adequate coverage from north to south of all wetland systems, management schemes, and levels of 
naturalness within each stratification (Yannuzzi Chapter 2). We classified wetland systems as either lacustrine, palustrine, or riverine. We distinguished wetland management schemes by those that were actively managed, passively managed, and unmanaged (Table 1). Last, we divided wetland naturalness into natural wetlands, modified wetlands, and created wetlands (Table 1). Wetland system and wetland naturalness modifiers were determined using data from the NWI (USFWS 2015). Wetland management schemes were determined through ground visits to wetland sites, where wetland system and naturalness modifiers were also verified.

\section{Moist-Soil Seed Production}

Field Collections -. We estimated moist-soil seed production at 37 wetlands between August and October of 2017 based on procedures from Gray et al. (1999a) and extrapolated to overall wetland size. At each wetland, we sampled dominant seeding plant species, defining dominant species as those that visually covered at least $1 / 6$ of wetland area during the time of sample collection. We did this in order to represent the main seed producers in the wetlands and felt this index permitted us to accurately portray the direct environment and characterize the most abundant plants on the direct landscape. We felt divisions of sixths were narrow enough to allow us to avoid inflating dominance by not including plants that were present in lesser concentrations, which otherwise might have been miscategorized had we determined dominance directly from within sample quadrats. Additionally, these plant species coincided with the diet of interior black ducks (Mendall 1949). We measured seed production within $151 \mathrm{~m}^{2}$ plots at each wetland site. For shallow wetlands $(\leq 60 \mathrm{~cm}$ throughout) with emergent or scrub-shrub vegetation, we placed plots randomly within the wetland basin. For deeper wetlands and rivers $(\geq$ $61 \mathrm{~cm})$, we placed plots randomly in the water within $10 \mathrm{~m}$ of the shore to estimate seed production in areas dabbling ducks could access, as these wetlands did not contain emergent 
vegetation and were primarily depths inaccessible to dabbling ducks, except around the edges of the water body where water was shallow and vegetation could persist. We counted the stems of each dominant seed-producing species within each $1 \mathrm{~m}^{2}$ plot and clipped one inflorescence of each dominant species from each plot and placed them in plastic bags on ice during transport to the lab. If no inflorescences of a dominant plant species were available in any of the 15 plots at a wetland, stems of the dominant species were still counted.

Laboratory Processing -. We kept inflorescences in the refrigerator for $<7$ days until we placed them in a plant press for at least one week. We placed pressed inflorescences on a dot grid (Gray et al. 1999a) and all dots partially or fully obscured by seeds were counted. We threshed seeds from the stem and dried them for $\geq 48$ hours at $50-55^{\circ} \mathrm{C}$ to constant mass and weighed seeds to the nearest $0.0001 \mathrm{~g}$.

\section{Benthic Core Sampling}

Field Collections -. We collected benthic core samples to determine seed and invertebrate biomass located within the substrate. We took core samples from 21 wetlands from March April $(\mathrm{n}=350)$ and November - December $2017(\mathrm{n}=360)$ using a handmade PVC corer $5 \mathrm{~cm}$ in diameter and $12 \mathrm{~cm}$ in depth (Livolsi et al. 2014). We collected 20 core samples at random points around each wetland when water depth and substrate allowed (Swanson 1983, Goldstein 2012). We allocated sampling to two transects per wetland, taking 10 samples randomly along each transect. We randomized sampling point locations with a random number generator to allocate distances between points on the transects, constrained to the length of the wetland. The starting point was set using the first randomly generated distance from the corner edge of the wetland. We collected samples along two perpendicular transects when wetland depth was $\leq 60$ $\mathrm{cm}$ throughout, and along two parallel transects close to shore when wetland depth was $\geq 61 \mathrm{~cm}$ 
throughout most of the wetland. Sampling was performed close to shore when wetlands were deep as we considered these areas $(\leq 60 \mathrm{~cm})$ as potentially accessible to dabbling ducks, and anything greater than that as inaccessible to dabbling ducks. We used two parallel transects to sample rivers and streams in the same method as deep water wetlands, with one transect on each side, but constrained transect length to $200 \mathrm{~m}$. Occasionally ( $\mathrm{n}=9$ wetlands), fewer than 20 samples were taken due to the random point falling in a part of the wetland that was too deep $(\geq$ $61 \mathrm{~cm}$ ) or had too rocky of a substrate to collect a sample. Such points were considered to have no food items due to the inability for a dabbling duck to forage in the benthic layer at these depths and in these substrates.

Laboratory Processing -. We bagged core samples at field sites, transported them to the lab on ice, and froze them prior to processing. We washed samples in size 10 and 60 sieves (Livolsi et al. 2014), separating material into large (size 10 mesh) and small material (size 60 mesh). We sorted $100 \%$ of the material, removing invertebrates and seeds. Due to time constraints, samples from the spring were stored in $70 \%$ ethanol while waiting to be identified. Invertebrates and seeds from the winter were identified immediately following sample washing and sorting. Cramer (2009) found that the different storage methods do not impact sample integrity. We identified invertebrates to family and seeds to genus when possible using Godfrey and Wooten (1979, 1981), Peckarsky et al. (1990), and Voshell (2002). We then dried seeds and invertebrates for $\geq 48$ hours at $50-55^{\circ} \mathrm{C}$ to constant mass and weighed them to the nearest $0.0001 \mathrm{~g}$ (Cramer 2009, Fino et al. 2017).

\section{Statistical Analysis}

Moist-Soil Seed Production -. We used general linear models to build predictive equations to estimate food resource biomass for dominant seeding plant species similar to methods used in 
Gray et al. $(1999 a, b)$. To evaluate goodness of fit, we considered models with Adjusted $\mathrm{R}^{2}$ values of $<0.60$ as having a poor fit and removed these plant species from calculations as these models did not have a reliable enough fit to accurately predict plant biomass and as such, duck use days.

We then extrapolated from stem biomass to wetland biomass. Average dot count, stem count, and seed mass were calculated per dominant plant species at each wetland. When inflorescences were unavailable in all 15 plots at a wetland, we incorporated grand average dot counts and masses for these species across all wetland samples into calculations as needed. Average stem density and average mass per species at each wetland were multiplied together to obtain average mass per plot $\left(\mathrm{g} / \mathrm{m}^{2}\right)$, summed, and then extrapolated to $\mathrm{kg} / \mathrm{ha}$ for each wetland. Benthic Core Sampling -. To estimate biomass of seeds and invertebrates, we extrapolated from $\mathrm{g} /$ core sample to $\mathrm{kg} / \mathrm{ha}$. We did this by first dividing mass (g/core; where the core sample was 5 $\mathrm{cm}$ in diameter $=19.63 \mathrm{~cm}^{2}$ ) of each food item in a core sample by 19.63 and extrapolating to $\mathrm{g} / \mathrm{ha}$. We then summed masses $(\mathrm{g} / \mathrm{ha})$ of the food items in each core sample and converted to $\mathrm{kg} / \mathrm{ha}$. Lastly, we calculated average mass $(\mathrm{kg} / \mathrm{ha})$ per wetland by taking the mean across all core samples taken at each wetland.

Estimating Energy -. To more accurately represent energetic supply in the landscape, we multiplied food item biomass by true metabolizable energy (TME) values taken from published literature for samples from both benthic core sampling and moist-soil seed production sampling (Appendix A). When unavailable, we used the average value of closely related food items or the average TME of all seeds or invertebrates (Livolsi 2015). We only included published preferred black duck food items in analysis to more accurately represent food availability for wintering black ducks (Mendall 1949, Cramer et al. 2012, Livolsi 2015, Fino et al. 2017). We determined 
an overall average energy value across all wetlands by taking the average of sampled wetland energy values from both core and seed production sampling.

We calculated potential duck-use days (DUDs) according to Reinecke et al. (1989):

$$
\text { DUD }=\frac{(\text { Food abundance }[\mathrm{g} \text { dry mass }] \times \text { true metabolizable energy }[\mathrm{kcal} / \mathrm{g} \text { dry mass }])}{(\text { daily energy expenditure }[\mathrm{DEE}])}
$$

We used a regional and black duck-specific estimate of $368.77 \mathrm{kcal} / \mathrm{bird} / \mathrm{day}$ calculated from time activity budgets taken within the study area between November and March 2015 - 2016 and 2016 - 2017 (Yannuzzi Chapter 2). To extrapolate our findings to all wetlands in the study area, we estimated energy per hectare of each habitat type (i.e., riverine, palustrine, and lacustrine) and extrapolated it to the regional area of the individual habitat types and combined aquatic systems. We determined total area of each habitat type from National Wetlands Inventory data (USFWS 2015) in ArcMap 10.5 (ESRI 2017). We also calculated interior buffers at $1 \mathrm{~m}, 5 \mathrm{~m}$, and $10 \mathrm{~m}$ within lacustrine and riverine systems to reflect a more accurate range of available habitat for waterfowl, as we assumed that both riverine and lacustrine systems were likely bowl shaped. From this, we estimated $8,993.31$ ha of riverine habitat with a $1 \mathrm{~m}$ buffer, $32,687.19$ ha with a 5 $\mathrm{m}$ buffer, and 35,696.52 ha with a $10 \mathrm{~m}$ buffer. The $10 \mathrm{~m}$ riverine buffer was not much larger than the $5 \mathrm{~m}$ buffer as many rivers in the study area were not wider than $20 \mathrm{~m}(10 \mathrm{~m}$ on each side). As such, when merging the buffers from all polylines, the merge accounted for any areas of overlap, resulting in a smaller overall area. Within lacustrine systems, we estimated 136.62 ha with a $1 \mathrm{~m}$ buffer, 675.78 ha with a $5 \mathrm{~m}$ buffer, and 1,324.69 ha with a $10 \mathrm{~m}$ buffer. Lastly, we calculated support for the number of individuals across the region by dividing DUDs by the number of days black ducks potentially use wintering wetlands in the region. This was determined to be 212 days, between 1 Sep and 31 Mar, taken from black duck wintering surveys conducted in New Jersey, USA (Fino et al. 2017). 
Using univariate general linear models, we related biomass from benthic core samples and from moist-soil seeds to levels of wetland naturalness, management schemes, wetland system type, and season (i.e., fall, spring, and late summer/early fall; Appendix B). To account for uncertainty and estimate means and standard error, we also bootstrapped our fitted linear models. We then performed t-tests to determine significant differences between each bootstrapped categorical predictor variable.

\section{RESULTS}

\section{Moist-Soil Seed Production}

Predictive Equations -. Twenty dominant plant species were determined from 37 sampled wetlands. We determined 14 of the plant species to have a biologically good fit when relating dots from the dot-grid to mass of inflorescences (Table 2). Six of the 20 dominant plant species were considered to have inadequate adjusted $\mathrm{R}^{2}$ values $(<0.60)$ and removed from duck use day calculations (Table 2).

Potential Duck Use Days -. We calculated biomass among wetland habitat systems (Table 3). Average seed biomass equaled $420.97(\mathrm{SE}=4.07) \mathrm{kg} / \mathrm{ha}$ and energy equaled 736,638 $(\mathrm{SE}=$ 7,404.17) $\mathrm{kcal} / \mathrm{ha}$ (Table 3). We calculated landscape-level energy across total wetland system area to be $120,792,185,777(\mathrm{SE}=1,214,135,056) \mathrm{kcal}$ and 327,554,264 $(\mathrm{SE}=3,292,391)$ potential DUDs total (Table 4). When dividing mean overall potential DUDs by the 212 days black ducks spend wintering during their annual life cycle across all habitat types, we calculated the number of individuals that could be accommodated to be 1,545,067 individuals. When incorporating the 1,5, and $10 \mathrm{~m}$ buffers around lacustrine and riverine systems, we determined landscape-level energy across wetland systems to be 67,933,934,981 - 88,479,711,697 (SE = $682,824,404-889,336,183) \mathrm{kcal}$ and $184,217,629-239,931,968(\mathrm{SE}=1,851,627-2,411,628)$ 
potential DUDs (Table 5). This resulted in 868,951.1 - 1,131,755 (SE = 8,734.09 - 11,375.6) individuals that could be accommodated within the 212 days of a black duck's wintering period.

Our t-tests on bootstrapped univariate linear models yielded significant results across all wetland systems, level of naturalness, and wetland management schemes. Palustrine systems contained greater seed biomass and energy than both lacustrine $(P<0.0001)$ and riverine systems $(P<0.0001)$ (Table 3; See Appendix C). Created wetlands contained greater seed biomass and energy than both modified $(P<0.0001)$ and natural wetlands $(P<0.0001)$ (Table 3 ; See Appendix D). Actively managed wetlands contained greater seed biomass than both passively $(P<0.0001)$ and unmanaged wetlands $(P<0.0001)$, and passively managed wetlands contained greater seed biomass than unmanaged wetlands $(P=0.013)$. However, unmanaged wetlands contained higher seed energy than passively managed wetlands $(P<0.0001)$ (Table 3 ; See Appendix E.).

\section{Benthic Core Sampling}

Energy Availability -. We identified 58 seed and 41 invertebrate types, totaling 99 taxa. Of these, 57 (58\%) were considered black duck food items (Mendall 1949, Cramer et al. 2012, Livolsi 2015). Twenty-six (46\%) were seeds and 31 (54\%) were invertebrates. Similarly, invertebrates represented $52 \%$ and seeds represented $48 \%$ of total energy of preferred black duck foods in sampled wetlands. Despite this, seeds represented $26 \%$ and invertebrates represented $74 \%$ of total biomass. Average winter (i.e., November - December 2017) biomass was 1,035.45 (SE = 334.66) and average spring (i.e., March - April 2017) biomass was 445.35 ( $\mathrm{SE}=371.96)$; however, we found no significant differences between seasonal biomass $(P=0.25)$, indicating minimal seasonal food depletion. As such, we combined samples across all seasons to increase the sample size for analysis (Cramer 2009, Livolsi 2015). 
Average biomass equaled $774.2 \mathrm{~kg} / \mathrm{ha}(\mathrm{SE}=7.93)$ (Table 6), with average seed items equaling $203.94 \mathrm{~kg} / \mathrm{ha}(\mathrm{SE}=1.06)($ Table 7$)$ and average invertebrate items equaling 571.3 (SE $=7.81) \mathrm{kg} / \mathrm{ha}$ (Table 8). From regional habitat area estimates, we determined regional energy availability, in which palustrine systems contained the highest energy levels (Table 4). Overall, the regional energy availability was determined to be $149,826,794,831$ ( $\mathrm{SE}=1,129,742,801)$ kcal when incorporating total wetland area. When incorporating only 1,5 , and $10 \mathrm{~m}$ buffers, we determined regional energy availability to be $84,261,953,704-109,745,937,327$ (SE = 635,362,558 - 827,520,089) (Table 5). Lastly, we found significant differences in overall biomass (Table 6), seed (Table 7), and macroinvertebrate (Table 8) biomass among different wetland systems, levels of naturalness, and management schemes. Combined biomass was greater in lacustrine systems than both palustrine $(P<0.0001)$ and riverine $(P<0.0001)$, and palustrine and riverine systems contained similar biomasses $(P=0.43)$ (See Appendix F). Despite this, riverine systems contained the highest cumulative energy, followed by lacustrine $(P$ $<0.0001)$, and lastly palustrine $(P=0.002)$ (Table 6). Cumulative biomass and energy was greatest in modified wetlands, which was greater than both created $(P<0.0001)$ and natural wetlands $(P<0.0001)$ (See Appendix G). Unmanaged wetlands contained greater cumulative biomass and energy than both active $(P<0.0001)$ and passively managed $(P<0.0001)$ wetlands (Table 6; See Appendix H).

Seed biomass was greatest in palustrine systems, followed by riverine $(P<0.0001)$, and lacustrine systems $(P<0.0001)$, but energy was highest in riverine systems, followed by palustrine $(P<0.0001)$, then lacustrine systems $(P<0.0001)$ (Table 7). Created wetlands contained the highest seed biomass and energy, followed by modified $(P<0.0001)$, and natural wetlands $(P<0.0001)$. Actively managed wetlands contained greater seed biomass than both 
passively managed $(P<0.0001)$ and unmanaged wetlands $(P<0.0001)$, but passively managed and unmanaged wetlands contained similar seed biomass $(P=0.34)$. However, in terms of seed energy, passively managed wetlands contained greater seed energy than unmanaged wetlands $(P$ $<0.0001)$ (Table 7).

Macroinvertebrate biomass and energy was greatest in lacustrine systems, followed by riverine $(P<0.0001)$, and palustrine systems $(P<0.0001)$ (Table 8$)$. Modified wetlands contained greater macroinvertebrate biomass and energy than both created and natural wetlands $(P<0.0001)$. However, biomass levels were similar between created and natural wetlands $(P=$ 0.112). Despite this, natural wetlands contained higher energy levels than created wetlands $(P<$ 0.0001). Unmanaged wetlands contained the highest macroinvertebrate biomass and energy, followed by actively $(P<0.0001)$ and passively managed $(P<0.0001)$ wetlands (Table 8$)$. Potential Duck Use Days -. Using regional energy availability and a regional daily energy expenditure value of $368.77 \mathrm{kcal} / \mathrm{bird} / \mathrm{day}$ based on time activity budgets calculated within the study area (Yannuzzi Chapter 2), we determined that riverine systems provided 154,828,544 (SE $=2,262,395)$ potential DUDs, lacustrine systems provided $64,656,718(\mathrm{SE}=802,408.8)$ potential DUDs, and palustrine systems provided 193,806,808 (SE = 2,176,167) potential DUDs (Table 4). Overall, we estimated a grand regional, all wetland systems encompassing estimate of 406,287,916 ( $\mathrm{SE}=3,063,543)$ potential DUDs region-wide (Table 4). Ultimately, using the grand regional estimate, this resulted in energy available for 1,916,452 individuals during the wintering period.

However, when incorporating the 1,5, and $10 \mathrm{~m}$ buffer around riverine and lacustrine systems, we found that potential DUDs were 228,494,600 - 297,599,960 ( $\mathrm{SE}=1,722,924$ - 
2,244,001) (Table 5). These estimates resulted in energy available for 1,077,805-1,403,773 (SE $=8,127-10,584.91)$ individuals during the wintering period.

\section{DISCUSSION}

\section{Moist-Soil Seed Production}

Incorporating moist-soil seed production to better understand plant biomass and wetland health is a useful tool for wetland managers. Our data showed that Gray et al.'s (1999a) dot-grid method to determine seeding plant biomass at wetlands proved to continue as a reliable technique when incorporated in other regions and with most other plant species. However, employing this technique only accounts for moist-soil seed biomass in a wetland, neglecting nutritious invertebrates, tubers, and acorns, and in the case of this study, also only incorporates the most dominant plant species, which may not always be the plants present with the highest biomass or energy per seed available. Additionally, removing seeding plant species with poor fit further made this estimate conservative. Despite this, moist-soil seed production accounted for a higher overall seed biomass than benthic core sampling and as such, may be a more reliable method when accounting solely for seed biomass. Furthermore, recent research has shown that sampling once throughout the season as opposed to multiple sampling occasions only accounts for $27 \%$ of available seed biomass (Hillhouse et al. 2018). As such, while our moist-soil estimates are more refined and higher than those from benthic core sampling, they are likely still a much more conservative estimate than actual available moist-soil seed biomass. Due to the sampling techniques deficiencies, we are led to believe that it is not a reliable sampling method for calculating potential duck use days for waterfowl when used without incorporating methods to retrieve other sources of available food at the same time of sampling. However, if we incorporated moist-soil seed estimates in combination with macroinvertebrate estimates from 
benthic core sampling, this would result in 111,074,277,245 - 197,502,000,000 (SE = $1,195,084,037-2,124,988,166) \mathrm{kcal}$ across the landscape, 301,202,043 - 301,202,043 (SE = $3,240,730-5,762,367$ ) potential DUDs, accounting for the support of 1,420,764 -2,526,272 (SE $=15,286.46-27,180.98)$ individuals throughout the 212 day wintering period.

\section{Benthic Core Sampling}

Filling a data gap in the western reaches of the black duck's wintering range, we estimated that our study region of north-central West Virginia and western Pennsylvania contains a total of $228,494,600-406,287,916(\mathrm{SE}=1,722,924-3,063,543)$ potential DUDs and can provide for up to $1,077,805-1,916,452$ birds throughout the wintering period. Palustrine systems provided the most cumulative energy in the study area because they make up the largest area of aquatic habitat in the region (USFWS 2015). We recognize that our estimates have potential for overestimation, as NWI does not incorporate water depth data into its repository and as such, we likely applied energy values to sections of wetlands that are not accessible to dabbling ducks. However, by applying buffers to deep water habitats, we felt that we were able to compensate for this and provide a more accurate range of estimates of available energy. Furthermore, we took core samples in almost twice the water depth than is the traditionally accepted foraging depth of $35 \mathrm{~cm}$, which allowed for some samples to be in water up to $60 \mathrm{~cm}$ (Guillemain et al. 2000). Having witnessed black ducks diving for food in the study area on three occasions during the wintering period of 2015-2016 and 2016-2017, we felt that incorporating somewhat increased depths into our estimates allowed for a more accurate representation of food availability. Despite this, only $11 \%(\mathrm{n}=74)$ of samples taken ended up being from water depths greater than $35 \mathrm{~cm}$, and as such, depth likely did not have a great impact in data biasing. However, we did not sample on agricultural fields or temporary wetlands that may not appear on NWI data layers, and 
as such our areas of potential overestimation are likely trivial as many sources of food were overlooked. It is also important to note that Central Appalachia experiences significant freeze throughout the winter. While we provided a range of estimates of available energy and individuals that could exist throughout the winter on this energy, these estimates are likely still an overestimation due to many of the wetlands in the study area being unavailable throughout much of the wintering period due to freeze up.

Our mean biomass estimate of $774.2 \mathrm{~kg} / \mathrm{ha}(\mathrm{SE}=7.93) \mathrm{kg} / \mathrm{ha}$ of black duck food energy was higher than previous black duck studies found in freshwater habitats, as Cramer et al. (2012) found freshwater wetlands in New Jersey to have a mean of $411(\mathrm{SE}=60) \mathrm{kg} / \mathrm{ha}$, Livolsi (2015) found freshwater impoundments in Delaware to hold $402.12(\mathrm{SE}=45.41) \mathrm{kg} / \mathrm{ha}$, and $217(\mathrm{SE}=$ 41) $\mathrm{kg} / \mathrm{ha}$ found on Long Island, NY (Plattner et al. 2010). Unlike in previous studies where freshwater black duck-preferred macroinvertebrate biomass was typically below $100 \mathrm{~kg} / \mathrm{ha}$ (Livolsi 2015, Cramer et al. 2012), Appalachian macroinvertebrate biomass accounted for 2.8 times the seed biomass availability, with invertebrate estimates more in the realm of mudflat and subtidal habitats, which yield between $413-1,516 \mathrm{~kg} / \mathrm{ha}$ (Cramer et al. 2012, Plattner et al. 2010). However, we estimated an overall seed biomass from moist-soil seed production that was 2.06 times higher than the overall seed biomass from benthic core sampling. In this scenario, macroinvertebrate biomass was only 1.36 times higher than seed biomass found from moist-soil seed production sampling, which when combined likely exhibits a more refined estimate of available biomass.

Contrary to our hypothesis, riverine systems yielded the most cumulative energy per hectare, but lacustrine systems contained the highest cumulative biomass per hectare. While lacustrine systems contained more macroinvertebrate biomass and energy than riverine systems, 
riverine systems contained higher seed biomass and energy. As such, the seeds found within riverine systems were likely high-quality seeds, resulting in an overall higher energy availability per hectare than in lacustrine systems. Within riverine systems, macroinvertebrate biomass was almost 3 times higher than seed biomass. Riverine systems, well known for their role in dispersal, encourage movements of invertebrate communities for purposes of food, competition, colonization, and more (Malmqvist 2002). This is particularly true for larger rivers, similar to those found in Central Appalachia, as past research has shown that invertebrate dispersal declines significantly the farther away it is from a large river (Kovats et al. 1996, Malmqvist 2002). As a result, Appalachian riverine systems are likely aiding in invertebrate dispersal, helping to meet the life cycle requirements of macroinvertebrates, thereby improving biomass.

Cumulative biomass and energy was highest in modified wetlands, with natural wetlands containing the lowest biomass and energy availability per hectare. Emergent vegetation is a common characteristic in modified wetlands, which creates the proper environment to provide for increased seed and macroinvertebrate abundance (Ma et al. 2010). It further provides for the nutritional, reproductive, and diapause needs of macroinvertebrates (Anderson and Smith 2000, Ma et al. 2010), which is reflected in modified systems containing the highest macroinvertebrate biomass.

Lastly and again contrary to our expectations, cumulative energy and biomass was highest in unmanaged wetlands and lowest in passively managed wetlands. Unmanaged wetlands contained the lowest seed biomass, but the highest macroinvertebrate and combined biomass. This pattern follows past research, in which Anderson and Smith (1998) found that unmanaged Texas playas received most of their available biomass and energy from invertebrates. As such, unmanaged wetlands are likely providing habitat that stimulates benthic invertebrate 
communities. Furthermore, unmanaged wetlands in Nebraska contained higher amounts of Gyraulus, Lymnaea, and Physa species due to more available cover (Davis and Bidwell 2008), which were also common invertebrates found throughout Appalachian wetlands, and likely contributed greatly towards increasing biomass and energy availability in unmanaged wetlands.

Throughout Central Appalachia, macroinvertebrate communities appear to be the main driver of available biomass and energy for wintering black ducks. Protein-rich invertebrates comprise $>90 \%$ of the wintering black duck diet, allowing for protein accumulation and storage to aid in survival and reproduction throughout their annual cycle (Reinecke et al. 1982, Costanzo and Malecki 1989, Anderson and Smith 1998, Cramer et al. 2012). As study area wetlands contain high invertebrate biomasses resulting in high energy estimates, black ducks wintering in Central Appalachia appear to be having their nutritional needs met not only for the wintering period, but also are probably carrying protein reserves over to the breeding season as well.

\section{MANAGEMENT IMPLICATIONS}

While previous data exists on gut content of wintering black ducks in both tidal and inland wetlands, these studies are performed in coastal states that provide a different composition of diet availability for wintering waterfowl (Mendall 1949, Cramer et al. 2012, Livolsi 2015). As such, we recommend that follow-up studies examine gut content of black ducks in the interior Appalachian Plateau of their range to narrow the list of preferred black duck foods and refine regional carrying capacity estimates. Additionally, we recommend that moist-soil seed production not be used as the sole predictor of duck use days, as it lacks the incorporation of important invertebrate biomass. However, using benthic core sampling solely for estimating macroinvertebrate biomass in conjunction with moist-soil seed production produces a more refined estimate, and as such, we recommend biologists and managers take this into 
consideration when estimating available wetland biomass and energy for calculating duck-use days. Furthermore, as seed biomass in both sampling techniques is uncharacteristically lower than macroinvertebrate biomass, we recommend that managers pay close attention to seasonal drawdown and flooding schemes where possible, as proper water level manipulation can improve seed biomass availability of desirable plants (Fredrickson and Taylor 1982).

\section{ACKNOWLEDGMENTS}

We are grateful for the financial support provided for this study by the U.S. Fish and Wildlife Service through the Black Duck Joint Venture, the Pennsylvania Game Commission, the West Virginia Division of Natural Resources, and West Virginia University. J. T. Anderson was supported by the National Science Foundation under Cooperative Agreement No. OIA-1458952, the USDA National Institute of Food and Agriculture, McIntire Stennis project WVA00117, and the West Virginia Agricultural and Forestry Experiment Station during manuscript preparation. We thank J. S. Carr, C. M. McDougal, M. A. Petschauer, J. Stempka, Z. R. Dienes, H. L. Warner, L. R. Stollings, M. P. Evers, S. B. Cua, J. J. Gordon, C. L. Rausch, L. A. Leightner, and M. L. Spindler for their assistance in both field and lab work. This is scientific article number xxxx of the West Virginia Agricultural and Forestry Experiment Station, Morgantown.

\section{LITERATURE CITED}

Anderson, J. T. and L. M. Smith. 1998. Protein and energy production in playas: implications for migratory bird management. Wetlands 18:437-446.

Anderson, J. T. and L. M. Smith. 1999. Carrying capacity and diel use of managed playa wetlands. Wildlife Society Bulletin 27:281-291.

Anderson, J. T., and L. M. Smith. 2000. Invertebrate response to moist-soil management of playa wetlands. Ecological Applications 10:550-558. 
Balcombe, C. K., J. T. Anderson, R. H. Fortney, and W. S. Kordek. 2005. Aquatic macroinvertebrate assemblages in mitigates and natural wetlands. Hydrobiologia 541:175-188.

Ballard, B. M., J. E. Thompson, M. J. Petrie, M. Checkett, and D. G. Hewitt. 2004. Diet and nutrition of northern pintails wintering along the southern coast of Texas. Journal of Wildlife Management 68:371-382.

Batt, B. D. J., A. D. Afton, M. G. Anderson, C. D. Ankney, D. H. Johnson, J. A. Kadlec, and G. L. Krapu. 1992. Ecology and management of breeding waterfowl. University of Minnesota Press, Minneapolis, MN.

Blandin, W. W. 1992. Population characteristics and simulation: modeling of black ducks. U.S. Fish and Wildlife Service Fish and Wildlife Research 11.

Bowyer, M. W., J. D. Stafford, A. P. Yetter, C. S. Hine, M. M. Horath, and S. P. Havera. 2005. Moistsoil plant seed production for waterfowl at Chautauqua National Wildlife Refuge, Illinois. American Midland Naturalist 154:331-341.

Checkett, J. M., R. D. Drobney, M. J. Petrie, and D. A. Graber. 2002. True metabolizable energy of moist-soil seeds. Wildlife Society Bulletin 30:1113-1119.

Cole, C. A. and R. P. Brooks. 2000. A comparison of the hydrologic characteristics of natural and created mainstem floodplain wetlands in Pennsylvania. Ecological Engineering $14: 221-231$.

Conroy, M. J., M. W. Miller, and J. E. Hines. 2002. Identification and synthetic modeling of factors affecting American black duck populations. Wildlife Monographs 150:1-64.

Costanzo, G. R. and R. A. Malecki. 1989. Foods of black ducks along coastal New Jersey. Dissertation, Cornell University, Ithaca, NY, USA. 
Cramer, D. M. 2009. Estimating habitat carrying capacity for American black ducks wintering in southern New Jersey. Thesis, University of Delaware, Newark, DE, USA.

Cramer, D. M., P. M. Castelli, T. Yerkes, and C. K. Williams. 2012. Food resource availability for American black ducks wintering in southern New Jersey. Journal of Wildlife Management 76:214-219.

Dahl, T. E. 1990. Wetlands losses in the United States 1780's to 1980's. U.S. Department of the Interior, Fish and Wildlife Service, Washington, D.C.

Dahl, T. E. 2011. Status and trends of wetlands in the conterminous United States 2004 to 2009. U.S. Department of the Interior, Fish and Wildlife Service, Washington, D.C.

Davis, C.A. and J. R. Bidwell. 2008. Response of aquatic invertebrates to vegetation management and agriculture. Wetlands 28:793-805.

Dugger, B. D., M. L. Moore, R. S. Finger, and M. J. Petrie. 2007. True metabolizable energy for seeds of common moist-soil plant species. Journal of Wildlife Management 71:1964-1967.

ESRI. 2017. ArcGIS Desktop: Release 10.5. Redlands, CA: Environmental Systems Research Institute.

Fennessy, S., M. Gernes, J. Mack, and D. H. Wardrop. 2002. Methods for evaluating wetland condition: using vegetation to assess environmental conditions in wetlands. Office of Water, U. S. Environmental Protection Agency, Washington, D. C.

Fino, S. R., C. K. Williams, M. C. Livolsi, K. M. Ringelman, J. M. Coluccy, P. K. Devers, P. M. Castelli. 2017. Carrying capacity of wintering American black ducks in forested wetlands. Journal of Wildlife Management 81:943-950.

Francis, C.M., J.R. Sauer, and J.R. Serie. 1998. Effect of restrictive harvest regulations on survival and recovery rates of black ducks. Journal of Wildlife Management 62(4): 1544-1557.

Fredrickson, L. H., and T. S. Taylor. 1982. Management of seasonally flooded impoundments 
for wildlife. US Department of Interior, Fish and Wildlife Service. Resource Publication no. 148 .

Fredrickson, L. H. and F. A. Reid. 1988. Nutritional values of waterfowl foods. in Cross, D. H., (ed). Waterfowl Management Handbook: U.S. Fish and Wildlife Service Fish and Wildlife Leaflet 13.1.1., Washington, D.C., USA.

Godfrey, R. K. and J. W. Wooten. 1979. Aquatic and wetland plants of southeastern United States: Monocotyledons. University of Georgia Press, Athens, GA, USA.

Godfrey, R. K. and J. W. Wooten. 1981. Aquatic and wetland plants of southeastern United States: Dicotyledons. University of Georgia Press, Athens, GA, USA.

Goldstein, M. 2012. A comparison of sampling methodologies to improve estimates of available foods for American black ducks in New Jersey. M.S. Thesis, University of Delaware, Newark, DE, USA.

Gray, M. J., R. M. Kaminski, and M. G. Brasher. 1999a. A new method to predict seed yield of moistsoil plants. Journal of Wildlife Management 63:1269-1272.

Gray, M. J., R. M. Kaminski, and G. Weerakkody. 1999b. Predicting seed yield of moist-soil plants. Journal of Wildlife Management 64:1261-1268.

Guillemain, M., H. Fritz, and S. Blais. 2000. Foraging methods can affect patch choice: an experimental study in Mallard (Anas platyrhynchos). Behavioural Processes 50:123-129.

Hartman, F. E. 1963. Estuarine wintering habitat for black ducks. Journal of Wildlife Management 27:339-347.

Hillhouse, H. L., L. Zilli, and B. E. Anderson. 2018. Timing and protocols for estimating seed production in moist-soil and Phalaris arundinacea dominated areas in Rainwater Basin wetlands. Wetlands 38:461-468. 
Hoffman, R. D. 1983. True metabolizable energy of seeds consumed by postbreeding ducks in Lake Erie marshes. Dissertation, Ohio State University, Columbus, OH, USA.

Hoffman, R. D. and T. A. Brookhout. 1985. Salt marsh vegetation recovery at salt hay farm wetland restoration sites on Delaware Bay. Ecological Engineering 25:240-251.

Jorde, D. G. and R. B. Owen, Jr. 1988, Efficiency of nutrient use by American black ducks wintering in Maine. Journal of Wildlife Management 52:209-214.

Kaminski, R. M., J. B. Davis, H. W. Essig, P. D. Gerard, and K. J. Reinecke. 2003. True metabolizable energy for wood ducks from acorns compared to other waterfowl foods. Journal of Wildlife Management 67:542-550.

Kovats, Z. E., J. J. H. Ciborowski, and L. D. Corkum. 1996. Inland dispersal of adult aquatic insects. Freshwater Biology 36:265-276.

Lenth, R. 2018. emmeans: Estimated Marginal Means, aka Least-Squares Means. R package version 1.1.2. <https://CRAN.R-project.org/package=emmeans >.

Livolsi, M. C., K. M. Ringelman, C. K. Williams. 2014. Subsampling reduces sorting effort for waterfowl foods in salt-marsh core samples. Journal of Fish and Wildlife Management 5(2): 380386.

Livolsi, M. C. 2015. Bioenergetics, behavior, and sea level rise: current status and future implications for wintering dabbling ducks in Delaware. M.Sc. Thesis, University of Delaware, Newark, USA.

Livolsi, M. C., K. M. Ringelman, J. M. Coluccy, M. T. DiBona, and C. K. Williams. 2015. Implications of uncertainty in true metabolizable energy estimates for estimating wintering waterfowl carrying capacities. Wildlife Society Bulletin 39:827-833.

Ma, Z., Y. Cai, B. Li, and J. Chen. 2010. Managing wetland habitats for waterbirds: an international perspective. Wetlands 30:15-27. 
Malmqvist, B. 2002. Aquatic invertebrates in riverine landscapes. Freshwater Biology 47:679-694.

McGilvrey, F. B. 1966. Fall food habits of ducks near Santee Refuge, South Carolina. Journal of Wildlife Management 30:577-580.

Mendall, H. L. 1949. Food habits in relation to black duck management in Maine. Journal of Wildlife Management 13:64-101.

Morton, J. M., A. C. Fowler, and R. L. Kirkpatrick. 1989. Time and energy budgets of American black ducks in winter. Journal of Wildlife Management 53:401-410.

National Audubon Society. 2010. The Christmas bird count historical results [online]. <http://www.christmasbirdcount.org > Accessed 1 Oct 2016.

National Climatic Data Center [NCDC]. 2018. Climate of West Virginia. National Oceanic and Atmospheric Administration. Asheville, NC. <https://www.ncdc.noaa.gov/climatenormals/ clim60/states/Clim_WV_01.pdf >. Accessed 1 May 2018.

National Weather Service [NWS]. 2018. Snowfall information. National Oceanic and Atmospheric Administration. 〈https://www.weather.gov/cle/snowfall_info〉. Accessed 1 May 2018.

Naylor, L. W. 2002. Evaluating moist-soil seed production and management in Central Valley Wetlands to determine habitat needs for waterfowl. Thesis, University of California, Davis, USA.

Peckarsky, B. L., P. R. Fraissinel, M. A. Penton, and D. J. Conklin, Jr. 1990. Freshwater macroinvertebrates of northeastern North America. Cornell University Press, Ithaca, NY, USA.

Pennsylvania State University [PSU]. 2016. The Pennsylvania state climatologist: regional data. Pennsylvania State Climate Office, University Park, PA. <http://climate.psu.edu/data/>.

Penny, E. J. 2003. Estimating moist-soil plant seed availability in the Mississippi Alluvial Valley. Thesis, Mississippi State University, Starkville, USA. 
Petrie, M. J., R. D. Drobney, and D. A. Graber. 1998. True metabolizable energy estimates of Canada Goose foods. Journal of Wildlife Management 62:1147-1152.

Plattner, D. M., M. W. Eichholz, and T. Yerkes. 2010. Food resources for wintering and spring staging black ducks. Journal of Wildlife Management 74:1554-1558.

Reinecke, K. J. and R. B. Owen, Jr. 1980. Food use and nutrition and black ducks nesting in Maine. Journal of Wildlife Management 44:549-558.

Reinecke, K. J., T. L. Stone, R. B. Owen, Jr. 1982. Seasonal carcass composition and energy balance of female black ducks in Maine. Condor 84:420-426.

Reinecke, K. J., R. M. Kaminski, D. J. Moorhead, J. D. Hodges, and J. R. Nassar. 1989. Mississippi Alluvial Valley. Pages 203-247 in L.M. Smith, R.L. Pederson, and R.M. Kaminski, editors. Habitat management for migrating and wintering waterfowl in North America. Texas Tech University Press, Lubbock, TX.

Sherfy, M. H. 1999. Nutritional value and management of waterfowl and shorebirds foods in Atlantic coastal moist-soil impoundments. Ph.D. Dissertation, Virginia Polytechnic Institute and State University, Blacksburg, Virginia, USA.

Sherfy, M. H., R. L. Kirkpatrick, and K. E. Webb, Jr. 2001. Nutritional consequences of gastolith ingestion in blue-winged teal: a test of the hard-seed-for-grit hypothesis. Journal of Wildlife Management 65:406-414.

Swanson, G. A. 1983. Benthic sampling for waterfowl foods in emergent vegetation. Journal of Wildlife Management 47: 821-823.

Vonbank, J. A., H. H. Hagy, and A. F. Casper. 2016. Energetic carrying capacity of riverine and connected wetlands of the Upper Illinois River for fall-migrating waterfowl. American Midland Naturalist 176:210-221. 
Voshell, J. R., Jr. 2002. A guide to common freshwater invertebrates of North America. The McDonald \& Woodward Publishing Company, Blacksburg, VA, USA.

U.S. Fish and Wildlife Service [USFWS]. 2014. Waterfowl Population Status, 2014. U.S. Department of the Interior, Washington, DC, USA.

U.S. Fish and Wildlife Service [USFWS]. 2015. National Wetlands Inventory website. U.S. Department of the Interior, Fish and Wildlife Service, Washington, D.C. <http://www.fws.gov/wetlands/>. 


\section{TABLES}

Table 1. Criteria for levels of wetland naturalness and wetland management schemes used for American black duck food and energy availability sampling in western Pennsylvania and northcentral West Virginia, March - April, August - October, and November - December 2017 (USEPA 2016).
Wetland modifier
Definition

Level of wetland naturalness

Created

Modified

Natural

Wetland management scheme

Actively managed

Passively managed

Unmanaged
A developed wetland that did not previously exist on an upland or deep water site; excavated.

A wetland site manipulated for one or more specific functions that changes the wetland's role.

A self-regulating wetland that is integrated ecologically with its surrounding landscape.

A wetland that has some type of water control device allowing for the potential for hydrologic artificial manipulation.

A wetland that is managed solely around the wetland basin, through cutting, mowing, burning, and planting.

A wetland that has no human-induced management. 
Table 2. Dominant plant species used to calculate predictive models in order to determine available biomass at wetlands. Seeds were collected from wetlands following methods from Gray et al. (1999a) in north-central West Virginia and western Pennsylvania in August-October 2017.

\begin{tabular}{|c|c|c|c|c|c|c|}
\hline $\begin{array}{l}\text { Dominant plant } \\
\text { species }\end{array}$ & $\mathrm{n}$ & $\operatorname{Adj} R^{2}$ & $\begin{array}{l}\text { F- } \\
\text { statistic }\end{array}$ & $\begin{array}{l}\text { Slope } \\
\text { coefficient }\end{array}$ & Intercept & $\begin{array}{l}\text { Used in } \\
\text { DUD } \\
\text { calculations }\end{array}$ \\
\hline Bidens frondosa & 15 & 0.91 & 142.4 & 0.004 & -0.084 & $\mathrm{Y}$ \\
\hline Carex lupulinus & 9 & 0.06 & 4.8 & 0.004 & -0.001 & $\mathrm{~N}$ \\
\hline C. lurida & 18 & 0.84 & 89.4 & 0.004 & -0.118 & $\mathrm{Y}$ \\
\hline C. vulpinoides & 3 & -0.47 & 0.4 & -0.001 & 0.083 & $\mathrm{~N}$ \\
\hline $\begin{array}{l}\text { Cephalanthus } \\
\text { occidentalis }\end{array}$ & 8 & 0.80 & 29.9 & 0.010 & 0.450 & $\mathrm{Y}$ \\
\hline Cyperus esculentus & 8 & 0.71 & 18.3 & 0.003 & 0.070 & $\mathrm{Y}$ \\
\hline $\begin{array}{l}\text { Dulichium } \\
\text { arundinaceum }\end{array}$ & 4 & 0.78 & 11.9 & 0.002 & -0.05 & $\mathrm{Y}$ \\
\hline Eleocharis obtusa & 15 & 0.63 & 24.5 & 0.006 & -0.005 & $\mathrm{Y}$ \\
\hline Juncus effusus & 27 & 0.54 & 31.5 & 0.004 & -0.035 & $\mathrm{~N}$ \\
\hline Leersia orzyoides & 41 & 0.60 & 62.22 & 0.002 & 0.008 & Y \\
\hline $\begin{array}{l}\text { Phalaris } \\
\text { arundinaceum }\end{array}$ & 8 & 0.03 & 1.2 & 0.002 & 0.035 & $\mathrm{~N}$ \\
\hline $\begin{array}{l}\text { Polygonum } \\
\text { hydropiperoides }\end{array}$ & 55 & 0.65 & 103.0 & 0.005 & -0.007 & $\mathrm{Y}$ \\
\hline P. pensylvanicum & 25 & 0.91 & 238.0 & 0.005 & -0.041 & $\mathrm{Y}$ \\
\hline P. persicaria & 12 & 0.95 & 208.6 & 0.003 & -0.015 & $\mathrm{Y}$ \\
\hline P. sagittatum & 23 & 0.34 & 12.21 & 0.003 & 0.002 & $\mathrm{~N}$ \\
\hline $\begin{array}{l}\text { Schoenoplectus } \\
\text { tabernaemontani }\end{array}$ & 5 & 0.95 & 82.9 & 0.004 & -0.078 & $\mathrm{Y}$ \\
\hline Scirpus cyperinus & 23 & 0.87 & 154.4 & 0.004 & 0.716 & $\mathrm{Y}$ \\
\hline
\end{tabular}




$\begin{array}{lcccccc}\text { S. purshianus } & 11 & 0.63 & 18.2 & 0.010 & -0.046 & \text { Y } \\ \begin{array}{l}\text { Setaria parviflora } \\ \text { Sparganium spp. }\end{array} & 12 & 0.91 & 117.9 & 0.007 & -0.043 & \mathrm{~N} \\ & 45 & 0.85 & 253.9 & 0.013 & -0.812 & \mathrm{Y}\end{array}$


Table 3. Estimated food availability ( $\mathrm{kg} / \mathrm{ha})$ and energy ( $\mathrm{kcal} / \mathrm{ha})$ calculated from moist-soil seed production sampling for wintering American black ducks in north-central West Virginia and western Pennsylvania taken in March - April and November - December 2017.

\begin{tabular}{|c|c|c|}
\hline \multirow[b]{2}{*}{ Wetland Type } & \multicolumn{2}{|c|}{ Moist-Soil Seed Biomass and Energy } \\
\hline & $\bar{x}$ & SE \\
\hline Overall Biomass & 420.97 & 4.07 \\
\hline Overall Energy & 736,638 & $7,404.17$ \\
\hline \multicolumn{3}{|l|}{ System } \\
\hline \multicolumn{3}{|l|}{ Biomass } \\
\hline Lacustrine & $132.6 \mathrm{~B}$ & 7.31 \\
\hline Palustrine & $682.1 \mathrm{~A}$ & 5.45 \\
\hline Riverine & $92.86 \mathrm{C}$ & 8.87 \\
\hline \multicolumn{3}{|l|}{ Energy } \\
\hline Lacustrine & $201,700 \mathrm{~B}$ & $13,186.54$ \\
\hline Palustrine & $1,198,769 \mathrm{~A}$ & $9,808.34$ \\
\hline Riverine & $128,907 \mathrm{C}$ & $16,799.14$ \\
\hline \multicolumn{3}{|l|}{ Naturalness } \\
\hline \multicolumn{3}{|l|}{ Biomass } \\
\hline Created & $538.5 \mathrm{~A}$ & 10.43 \\
\hline Modified & $450.2 \mathrm{~B}$ & 5.91 \\
\hline Natural & $310.4 \mathrm{C}$ & 7.33 \\
\hline \multicolumn{3}{|l|}{ Energy } \\
\hline Created & $941,137 \mathrm{~A}$ & $19,424.11$ \\
\hline Modified & $759,038 \mathrm{~B}$ & $10,915.90$ \\
\hline Natural & $532,388 \mathrm{C}$ & $12,810.26$ \\
\hline \multicolumn{3}{|l|}{ Management } \\
\hline \multicolumn{3}{|l|}{ Biomass } \\
\hline Active & $492.5 \mathrm{~A}$ & 5.42 \\
\hline Passive & $339.7 \mathrm{~B}$ & 7.98 \\
\hline Unmanaged & $308.6 \mathrm{C}$ & 9.57 \\
\hline \multicolumn{3}{|l|}{ Energy } \\
\hline Active & $933,408 \mathrm{~A}$ & $9,869.77$ \\
\hline Passive & $406,997 \mathrm{C}$ & $15,135.35$ \\
\hline Unmanaged & $569,371 \mathrm{~B}$ & $17,368.31$ \\
\hline
\end{tabular}

${ }^{a}$ Means followed by the same uppercase letter down columns per category are not significantly different from each other $(P>0.05)$. 
Table 4. Estimated landscape-level duck use days (DUDs) and energy (kcal) from moist soil seed production sampling and benthic core sampling for wintering American black ducks in northcentral West Virginia and western Pennsylvania taken in March - April and November December 2017.

\begin{tabular}{crr}
\hline & \multicolumn{2}{c}{ Landscape-level DUDs and Energy } \\
\cline { 2 - 3 } Wetland Type & \multicolumn{1}{c}{ Total $\bar{x}$} & \multicolumn{1}{c}{ SE } \\
\hline Moist-soil seed & & \\
Overall DUD & $327,554,264$ & $3,292,391$ \\
Overall energy & $120,792,185,777$ & $1,214,135,056$ \\
DUD & & \\
Lacustrine & $14,397,394$ & 941,258 \\
Palustrine & $270,107,976$ & $2,210,026$ \\
Riverine & $19,073,839$ & $2,485,700$ \\
Energy & & \\
Lacustrine & $5,309,326,913$ & $347,107,842$ \\
Palustrine & $99,607,718,154$ & $814,991,351$ \\
Riverine & $7,033,859,440$ & $916,651,458$ \\
Benthic cores & & \\
Overall DUD & $406,287,916$ & $3,063,543$ \\
Overall energy & $149,826,794,831$ & $1,129,742,801$ \\
DUD & & \\
Lacustrine & $64,656,718$ & $802,408.80$ \\
Palustrine & $193,806,808$ & $2,176,167$ \\
Riverine & $154,828,544$ & $2,262,395$ \\
Energy & & \\
Lacustrine & $23,843,458,022$ & $295,904,293$ \\
Palustrine & $71,470,136,667$ & $802,505,165$ \\
Riverine & $57,096,122,324$ & $834,303,569$ \\
\hline
\end{tabular}


Table 5. Estimated landscape-level duck use days (DUDs) and energy (kcal) from moist soil seed production sampling and benthic core sampling for wintering American black ducks in northcentral West Virginia and western Pennsylvania taken in March - April and November -

December $2017.1 \mathrm{~m}, 5 \mathrm{~m}$, and $10 \mathrm{~m}$ buffers of lacustrine and riverine system area are applied to estimates. Overall estimates incorporate unbuffered, total area of palustrine wetlands.

\begin{tabular}{|c|c|c|c|c|c|c|}
\hline \multirow[b]{3}{*}{$\begin{array}{l}\text { Wetland } \\
\text { Type }\end{array}$} & \multicolumn{6}{|c|}{ Landscape-level DUDs and Energy } \\
\hline & \multicolumn{2}{|c|}{$1 \mathrm{~m}$ buffer } & \multicolumn{2}{|c|}{$\underline{5 \mathrm{~m} \text { buffer }}$} & \multicolumn{2}{|c|}{$10 \mathrm{~m}$ buffer } \\
\hline & $\bar{x}$ & SE & $\bar{x}$ & SE & $\bar{x}$ & SE \\
\hline \multicolumn{7}{|l|}{$\begin{array}{l}\text { Moist-soil } \\
\text { seed }\end{array}$} \\
\hline $\begin{array}{c}\text { Overall } \\
\text { DUD }\end{array}$ & $184,217,629$ & $1,851,627$ & $232,624,436$ & $2,338,178$ & $239,931,968$ & $2,411,628$ \\
\hline $\begin{array}{l}\text { Overall } \\
\text { energy } \\
\text { DUD }\end{array}$ & $67,933,934,981$ & $682,824,404$ & $85,784,913,100$ & $862,249,952$ & $88,479,711,697$ & $889,336,183$ \\
\hline Lacustrine & $74,724.77$ & $4,885.28$ & $369,620.2$ & $24,164.66$ & $724,543.7$ & $47,368.49$ \\
\hline $\begin{array}{l}\text { Riverine } \\
\text { Energy }\end{array}$ & $3,143,696$ & $409,685.9$ & $11,426,113$ & $1,489,049$ & $12,478,052$ & $1,626,138$ \\
\hline Lacustrine & $27,556,254$ & $1,801,545$ & $136,304,826$ & $8,911,200$ & $267,189,973$ & $17,468,078$ \\
\hline Riverine & $1,159,300,612$ & $151,079,874$ & $4,213,607,601$ & $549,116,681$ & $4,601,531,304$ & $599,670,837$ \\
\hline \multicolumn{7}{|l|}{$\begin{array}{l}\text { Benthic } \\
\text { cores }\end{array}$} \\
\hline $\begin{array}{c}\text { Overall } \\
\text { DUD }\end{array}$ & $228,494,600$ & $1,722,924$ & $288,536,052$ & $2,175,656$ & $297,599,960$ & $2,244,001$ \\
\hline $\begin{array}{c}\text { Overall } \\
\text { energy } \\
\text { DUD }\end{array}$ & $84,261,953,704$ & $635,362,558$ & $106,403,440,022$ & $802,316,571$ & $109,745,937,327$ & $827,520,089$ \\
\hline Lacustrine & $335,578.7$ & $4,164.63$ & $1,659,913$ & $20,600.01$ & $3,253,826$ & $40,380.93$ \\
\hline $\begin{array}{l}\text { Riverine } \\
\text { Energy }\end{array}$ & $25,518,398$ & $372,881.6$ & $92,749,470$ & $1,355,280$ & $101,288,404$ & $1,480,053$ \\
\hline Lacustrine & $123,751,352$ & $1,535,791$ & $612,126,254$ & $7,596,666$ & $1,199,913,475$ & $14,891,277$ \\
\hline Riverine & $9,410,419,718$ & $137,507,530$ & $34,203,221,872$ & $499,786,481$ & $37,352,124,598$ & $545,799,077$ \\
\hline
\end{tabular}


Table 6. Estimated food availability ( $\mathrm{kg} / \mathrm{ha}$ ) and energy ( $\mathrm{kcal} / \mathrm{ha})$ of combined seeds and macroinvertebrates calculated from benthic core sampling for wintering American black ducks in north-central West Virginia and western Pennsylvania taken in Mar - April and Nov - Dec 2017.

\begin{tabular}{ccc}
\hline & Cumulative Benthic Biomass and Energy \\
\cline { 2 - 3 } Wetland Type & $\bar{x}$ & SE \\
\hline Overall Biomass & 774.20 & 7.93 \\
Overall Energy & 913,690 & $6,889.52$ \\
System & & \\
Biomass & & \\
Lacustrine & $947.7 \mathrm{~A}$ & 14.21 \\
Palustrine & $677.8 \mathrm{~B}$ & 11.48 \\
Riverine & $694.8 \mathrm{~B}$ & 18.17 \\
Energy & & \\
Lacustrine & $905,807 \mathrm{~B}$ & $11,241.33$ \\
Palustrine & $860,136 \mathrm{C}$ & $9,658.07$ \\
Riverine & $1,046,380 \mathrm{~A}$ & $15,289.98$ \\
Naturalness & & \\
Biomass & & \\
Created & $453.67 \mathrm{~B}$ & 19.70 \\
Modified & $1,182.31 \mathrm{~A}$ & 10.84 \\
Natural & $251.18 \mathrm{C}$ & 13.90 \\
Energy & & \\
Created & $800,699 \mathrm{~B}$ & $16,178.08$ \\
Modified & $1,190,272 \mathrm{~A}$ & $9,007.09$ \\
Natural & $475,385 \mathrm{C}$ & $12,156.44$ \\
Management & & \\
Biomass & & 10.80 \\
Active & $781.5 \mathrm{~B}$ & 16.65 \\
Passive & $219.1 \mathrm{C}$ & 15.83 \\
Unmanaged & $1,319.5 \mathrm{~A}$ & \\
Energy & & $9,305.93$ \\
Active & $926,999 \mathrm{~B}$ & $13,878.01$ \\
Passive & $381,130 \mathrm{C}$ & \\
Unmanaged & $1,370,978 \mathrm{~A}$ & \\
& &
\end{tabular}

${ }^{a}$ Means followed by the same uppercase letter down columns per category are not significantly different from each other $(P>0.05)$. 
Table 7. Estimated seed biomass $(\mathrm{kg} / \mathrm{ha})$ and energy $(\mathrm{kcal} / \mathrm{ha})$ calculated from benthic core sampling for wintering American black ducks in north-central West Virginia and western Pennsylvania taken in March - April and November - December 2017.

\begin{tabular}{ccc}
\hline & \multicolumn{2}{c}{ Benthic Seed Biomass and Energy } \\
\cline { 2 - 3 } Wetland Type & $\bar{x}$ & SE \\
\hline Overall Biomass & 203.94 & 1.06 \\
Overall Energy & 437,026 & $2,447.88$ \\
System & & \\
Biomass & & \\
Lacustrine & $139.48 \mathrm{C}$ & 1.83 \\
Palustrine & $251.6 \mathrm{~A}$ & 1.45 \\
Riverine & $178.72 \mathrm{~B}$ & 2.34 \\
Energy & & \\
Lacustrine & $315,949 \mathrm{C}$ & $4,610.78$ \\
Palustrine & $460,478 \mathrm{~B}$ & $3,705.78$ \\
Riverine & $602,163 \mathrm{~A}$ & $6,011.52$ \\
Naturalness & & \\
Biomass & & \\
Created & $421.5 \mathrm{~A}$ & 2.32 \\
Modified & $162.66 \mathrm{~B}$ & 1.27 \\
Natural & $158.50 \mathrm{C}$ & 1.65 \\
Energy & & \\
Created & $760,918 \mathrm{~A}$ & $6,437.48$ \\
Modified & $456,683 \mathrm{~B}$ & $3,384.62$ \\
Natural & $273,898 \mathrm{C}$ & $4,571.18$ \\
Management & & \\
Biomass & & \\
Active & $242.30 \mathrm{~A}$ & 1.44 \\
Passive & $156.1 \mathrm{~B}$ & 2.11 \\
Unmanaged & $153.26 \mathrm{~B}$ & 2.10 \\
Energy & & \\
Active & $558,532 \mathrm{~A}$ & $3,467.88$ \\
Passive & $350,205 \mathrm{~B}$ & $5,023.05$ \\
Unmanaged & $286,689 \mathrm{C}$ & $5,107.04$ \\
& & \\
\hline
\end{tabular}

${ }^{\mathrm{a}}$ Means followed by the same uppercase letter down columns per category are not significantly different from each other $(P>0.05)$. 
Table 8. Estimated macroinvertebrate biomass $(\mathrm{kg} / \mathrm{ha})$ and energy ( $\mathrm{kcal} / \mathrm{ha})$ calculated from benthic core sampling for wintering American black ducks in north-central West Virginia and western Pennsylvania taken in March - April and November - December 2017.

\begin{tabular}{ccc}
\hline & \multicolumn{2}{c}{ Benthic Macroinvertebrate } \\
Wetland Type & $\bar{x}$ & SE \\
\cline { 2 - 3 } Overall Biomass & 571.30 & 7.81 \\
Overall Energy & 467,790 & $5,554.66$ \\
System & & \\
Biomass & & 14.24 \\
Lacustrine & $844.0 \mathrm{~A}$ & 11.13 \\
Palustrine & $432.0 \mathrm{C}$ & 18.04 \\
Riverine & $533.2 \mathrm{~B}$ & \\
Energy & & $10,482.14$ \\
Lacustrine & $586,539 \mathrm{~A}$ & $8,242.51$ \\
Palustrine & $388,110 \mathrm{C}$ & $13,977.72$ \\
Riverine & $428,541 \mathrm{~B}$ & \\
Naturalness & & 18.93 \\
Biomass & & 10.21 \\
Created & $94.0 \mathrm{~B}$ & 13.88 \\
Modified & $1,033.6 \mathrm{~A}$ & \\
Natural & $83.31 \mathrm{~B}$ & $14,165.30$ \\
Energy & & $7,742.68$ \\
Created & $32,586 \mathrm{C}$ & $10,168.02$ \\
Modified & $748,416 \mathrm{~A}$ & \\
Natural & $196,179 \mathrm{~B}$ & 10.53 \\
Management & & 16.45 \\
Biomass & & 16.16 \\
Active & $519.1 \mathrm{~B}$ & $7,636.06$ \\
Passive & $101.05 \mathrm{C}$ & $11,525.15$ \\
Unmanaged & $1,146.8 \mathrm{~A}$ & $11,701.85$ \\
Energy & $365,441 \mathrm{~B}$ & \\
Active & $31,777 \mathrm{C}$ & \\
Passive & $1,110,904 \mathrm{~A}$ & \\
Unmanaged & & \\
& & \\
\hline & & \\
\hline
\end{tabular}

${ }^{a}$ Means followed by the same uppercase letter down columns per category are not significantly different from each other $(P>0.05)$. 


\section{Chapter 2: Daily Energy Expenditure and Activities of Wintering American Black Ducks}

ABSTRACT American black ducks (Anas rubripes), a once plentiful species in northeastern North America, have been in decline for over half a century due to habitat loss, hybridization with mallards (Anas platyrhynchos), and historic overhunting. While the overall population of black ducks has stabilized and even increased in portions of its range, important wintering areas in western Pennsylvania and West Virginia have continued to see a decrease. Our objectives were to determine wintering black duck daily energy expenditure (DEE) in Central Appalachia through time-activity budgets, and calculate behavioral differences among wetland systems, levels of naturalness, management schemes, flock composition, year, date, and time of day. Between November and March 2015-2016 and 2016-2017, we conducted waterfowl surveys twice a month and recorded diurnal time-activity budgets when black ducks were encountered. We calculated DEE using both a simple cost of thermoregulation model (684.94 kJ/bird/day) and a complex $(1,542.95 \mathrm{~kJ} / \mathrm{bird} /$ day $)$ cost of thermoregulation model incorporating site-level wind speeds and temperatures. Swimming was the most dominant behavior overall (35.2\%), followed by foraging $(26.2 \%)$, and sleeping $(16.4 \%)$. Black ducks foraged the most in natural wetlands $(56 \%)$ and riverine systems $(34 \%)$ and swam the most in modified $(43 \%)$ and created $(26 \%)$ wetlands. Black duck behavior varied greatly within wetland systems, management schemes, and levels of naturalness. As such, we recommend wetland and waterfowl managers incorporate the complex cost of thermoregulation DEE model for more accurate estimations of duck use days, and provide a diversity of nearby habitat types with differing levels of management for wintering waterfowl to meet their multitude of needs throughout the winter.

KEY WORDS Anas rubripes, mallard, waterfowl, wetlands, wetland management 
American black ducks (Anas rubripes; hereafter, black ducks) are a member of the mallard complex found in the northeastern part of North America, primarily concentrating along the Atlantic Coast, with smaller inland densities (Longcore et al. 2000, Baldassarre 2014). Since the 1950s, black ducks have seen a range-wide population decline from $\sim 750,000$ to $\sim 288,000$ birds (USFWS 2014). This is commonly attributed to historic overharvest, the decline in the amount and degradation of both breeding and wintering habitat, and competition and hybridization with the closely related mallard (A. platyrhynchos) (Blandin 1992, Francis et al. 1998, Conroy et al. 2002). Owing to past harvest moratoriums and restrictions, black duck harvest is not widely regarded as a threat to the population (Nichols 1991, Newcomb et al. 2015, ABDAHMWG 2017).

However, wetlands are still drained and filled, with approximately a 53\% decline in North America's overall wetland area due to agriculture, rural and urban development, silviculture, and other anthropogenic activities, reflecting a similar decline to the black duck population decrease (Dahl 2000, 2011). Many states lost over 50\% of their total wetland area, including Pennsylvania (56\%). Remaining states still lost a significant portion of their wetland area, such as West Virginia (24\%) (Dahl 1990, Dahl et al. 1991).With wetland policies such as "no net loss" of wetlands in the late 1980s and the Emergency Wetlands Resources Act of 1986 drawing attention to wetland creation, restoration, and monitoring, annual wetland loss of 185,346 ha in the 1970s was reversed to an annual gain of 8,863 ha between 2004 and 2009 (Dahl 2000, 2011).

The majority of black duck research has been performed in the core part of their wintering range along the Atlantic Coast, and on the breeding grounds in Maine and Canada. Wintering studies (Wooley and Owen 1978, Jones et al. 2014, Livolsi et al. 2014, Livolsi et al. 
2015a, Ringelman et al. 2015, O'Connor 2016, Fino et al. 2017) have measured bioenergetics and food availability of black ducks in the mid-Atlantic and also under captive conditions. In order to accurately estimate regional carrying capacity of waterfowl, studies must determine a daily energy expenditure component which calculates how much energy a duck spends in a single day using a species' resting metabolic rate (RMR), thermoregulatory needs, and behavioral energy costs (McKinney and McWilliams 2005). Past studies have typically done this through diurnal behavioral observations and allometric equations, using fixed, none, or simple temperature-driven thermoregulatory components (SCT) which do not account for all thermoregulatory costs on wintering birds, resulting in DEE values ranging from 665.42 to 1,349.01 kJ/bird/day (Albright et al. 1983, Miller and Eadie 2006, Jones et al. 2014). Black duck behavior changes in response to weather, time of day, tide, food availability, habitat, and ice coverage, which could impact estimates of daily energy expenditure, and ultimately approximations of carrying capacity (Albright et al. 1983, Longcore and Gibbs 1988, Morton et al. 1989). As such, recent studies have incorporated a complex cost of thermoregulation component into daily energy expenditure calculations, including wind speed, temperature, and species-specific morphometrics to more accurately determine energy expenditure and regional carrying capacity, resulting in higher estimates between 1,176.04-1,418.04 kJ/bird/day (Livolsi 2015, Livolsi et al. 2015a).

Despite the plethora of research performed on black ducks in their core range, extrapolating behavior and subsequent energy expenditure estimations to the western reaches of black duck range, where habitat and weather patterns differ, could lead to errors in estimations of regional carrying capacity. Only a select few have studied black ducks in the western edge of their wintering range with this work primarily performed in Tennessee, focusing on wintering 
black duck survival, food availability, and behaviors, but not specifically calculating for daily energy expenditure (Newcomb 2014, McClanahan 2015, Osborn et al. 2017). Differences in regional habitat use and availability could have further implications on behavior and resultant energy expenditure, as past research has shown that Tennessee-wintering black ducks selected for emergent and scrub-shrub wetlands (Newcomb 2014, McClanahan 2015), whereas Atlanticwintering black ducks took advantage of a variety of tidal and non-tidal wetlands, but particularly salt marsh and impoundments (Albright et al. 1983, Morton et al. 1989). Black ducks wintering along the Atlantic fed in tidal marshes and rested in refuge pools, while farther west in their range they fed on flooded croplands and moist-soil areas and rested in larger marshes and shrubby wetlands (Morton et al. 1989, Reinecke et al. 1989). Varying offerings, such as biomass and microclimate, from different habitat types can result in dissimilar behaviors, which ultimately impacts daily energy expenditure.

Behavioral responses of wintering black ducks, such as congregating in large flocks and resting in sheltered environments, have been documented and are considered a response to mitigating increasing energetic demands from winter weather (Longcore and Gibbs 1988). Mallards, too, select for thermally favorable environments, such as wastewater treatment ponds where densities increased when air temperatures were low (Welsh et al. 2017). This has also been evidenced in other avian species such as the Verdin (Auriparus flaviceps), which selected for microclimates that provided thermoregulatory benefits (Wolf and Walsberg 1996). Choosing habitats that provide relief from winter weather is vital to the thermoregulation, and ultimately survival, of wintering birds, yet black duck DEE has not been measured in relation to different environments (Calder and King 1974, Longcore and Gibbs 1988). While some research has been conducted on wetland productivity and wildlife communities in West Virginia and western 
Pennsylvania where a portion of the overall black duck population resides during both migratory and wintering periods (Balcombe et al. 2005a, Balcombe et al. 2005b, Veselka et al. 2010, Clipp et al. 2017), important wintering habitat for black ducks has not been intensively examined in this region. With differences in behaviors, habitat use and availability, and weather patterns, it is important to calculate daily energy expenditure separately for Appalachian-wintering black ducks to better inform estimations of regional carrying capacity.

Since black duck numbers have not increased despite efforts to increase available habitat, the quality and use of existing habitat remains in question. There is increasing information on the success of wetland mitigation, in which wetlands are enhanced, restored, or created; however, results are often conflicting and much research is still needed particularly in support of impacts on wildlife and particularly waterfowl (Balcombe et al. 2005a). Waterfowl presence has been found to be higher in mitigated wetlands than in natural wetlands, but both wetland types are thought to provide different kinds of support, with open water natural wetlands providing higher benthic macroinvertebrate densities (Balcombe et al. 2005b). Regardless, freshwater wetlands found in the Appalachian Plateau lack the invertebrate densities of important wintering coastal mudflats, making seeds the most available food item to inland black ducks (Plattner et al. 2010, Cramer et al. 2012, Livolsi et al. 2015b). Cole and Brooks (2000) found that created wetlands in Pennsylvania remained inundated year-round and were primarily open water, while natural wetlands dried seasonally and had significant herbaceous cover. This seasonal inundation of wetlands allows for plant growth and invertebrate hatches, providing biomass for wintering waterfowl (Anderson and Smith 2000). As such, Cole and Brooks' (2000) findings suggest that created wetland conditions are not measuring up to the provisions of natural wetlands. 
Relative success of mitigated wetlands depends greatly on both creation and management practices. Black ducks wintering in Tennessee maintained high nocturnal concentrations in actively managed wetlands (i.e., wetlands where water levels are artificially manipulated), likely for foraging and roosting activities (Newcomb 2014). In the Mississippi Alluvial Valley, actively managed wetlands were found to have higher seed abundance than passively managed wetlands (Kross et al. 2008), a trait which extended to invertebrate biomass on the Southern High Plains, where managed playa wetlands contained higher abundances than unmanaged ones (Anderson and Smith 2000). In Illinois, managed wetlands unattached from river systems yielded higher seed and tuber densities than natural wetlands, but when connected to a river saw great seed dispersal and as such, a lower carrying capacity (Vonbank et al. 2016).

In addition to floristic and biomass disparities between wetland naturalness levels and management regimes, waterfowl use of a variety of available wetlands needs further investigation. Waterbirds have been documented using created commercial fish ponds in times of heavy drought when natural wetlands dried (Kloskowski et al. 2009). Clipp et al. (2017) found that two created wetlands in West Virginia had high waterfowl species richness throughout migration and wintering periods, but that wetland age and habitat complexity determined which species used which wetland type. For example, Clipp et al. (2017) witnessed diving ducks and Canada geese (Branta canadensis) using the older created wetland more than the dabbler species which used the younger created wetland. Additionally, black ducks, mallards, and wood ducks (Aix sponsa) were witnessed using an open stream attached to the younger created wetland complex when the rest of the wetland was frozen (Clipp et al. 2017). In South Carolina, Bergan and Smith (1989) observed buffleheads (Bucephala albeola), lesser scaup (Aythya affinis), ruddy ducks (Oxyura jamaicensis), and ring-necked ducks (A. collaris) using different wetland 
subsystems as winter progressed and suggested that females and ruddy ducks used areas that provided a comfortable microclimate to seek shelter from harsh conditions when winter weather was poor. As such, having a wide array of high quality habitat types available for waterfowl during the wintering period is likely important to provide for the diversity of needs of wintering waterfowl (Osborn et al. 2017).

The Appalachian Plateau contains $2.8-8.9 \%$ of all wintering black ducks, making it an important stronghold on the western edge of the Atlantic Flyway (National Audubon Society 2010). The objective of our study was to determine energy expenditure of wintering black ducks regionally and in differing wetland habitats throughout Central Appalachia by means of diurnal time-activity budgets. We hypothesized that black ducks would spend more time swimming and loafing in riverine and lacustrine systems, and passively managed and unmanaged wetlands, and that they would spend more time foraging in actively managed wetlands and palustrine systems. We also hypothesized that black ducks would use natural wetlands for courtship and pair bonding activities, and created and modified wetlands for loafing. As such, we hypothesized that black duck DEE would be higher in actively managed wetlands and palustrine systems, and lower in riverine and lacustrine systems. Our goal is to ultimately determine the driving factors behind wintering black duck habitat use with the aim of improving management for the species in this region to contribute to the North American Waterfowl Management Plan's goal of 675,000 black ducks range-wide.

\section{STUDY AREA}

The study area extended from north-central West Virginia, northwards to the shores of Lake Erie in Erie County, Pennsylvania, and west to the borders of Pennsylvania and West Virginia $(3,479,300$ ha; Figure 1). The area is comprised of 2 physiographic regions: the Central 
Lowlands around Erie County, PA, and the Appalachian Plateau and ranges in elevation from $173-978 \mathrm{~m}$ (Sevon 2000). The study area is mostly made of characteristic sedimentary rocks of the Appalachian Plateau (i.e., subhorizontal beds, shale, siltstone, sandstone, limestone, red beds, conglomerate, and some coal), with the Central Lowlands having underlying shale and siltstone rock (Sevon 2000, WVGES 2015). The study area is divided into 6 categories: Freshwater Emergent, Freshwater Forested/Scrub-Shrub, Freshwater Pond, Riverine, Lake, and Other (USFWS 2015). The most abundant systems were palustrine (83,091.67 ha), followed by riverine systems (54,565.38 ha), and lacustrine systems (26,322.89 ha). Local average annual precipitation ranges from 91 to $122 \mathrm{~cm}$ with local mean monthly temperatures falling between -5 and $21.5^{\circ} \mathrm{C}$ (PADCNR 2000, Sevon 2000, PSU 2016). Mean temperature during the study period in both years combined was $4.43^{\circ} \mathrm{C}$, with the first year of the study $(2015-2016)$ averaging $4.15^{\circ} \mathrm{C}$ and the second year (2016 - 2017) averaging $4.72{ }^{\circ} \mathrm{C}$ (See Appendix I; NCEI 2017). However, monthly averages varied drastically between years.

\section{METHODS}

\section{Behavioral Observation Sample Selection}

We chose a random sample of wetlands from 10 even-width stratifications in the study area based on latitude to ensure relatively equal coverage from north to south. From this, we formed 10 survey routes in the first year study area-wide, with 5 in Pennsylvania and 5 in West Virginia. We chose surveyed wetlands along survey routes with different wetland management schemes, levels of naturalness, and wetland systems using National Wetlands Inventory data. We separated the wetland naturalness predictor variable into 4 subcategories: natural wetlands, modified wetlands, and created wetlands (Table 1). We defined the wetland management scheme predictor variable into 3 categories: actively managed wetlands, passively managed wetlands, 
and unmanaged wetlands (Table 1). Lastly, we partitioned the wetland system predictor variable into 3 categories: lacustrine, palustrine, and riverine systems. Survey routes were comprised of approximately 6 wetlands each, with enough survey points at each wetland to adequately view the entire waterbody, typically ranging from $1-3$ points. Each survey point was placed at the edge of the wetland being surveyed. Each survey route was set up to take approximately 8 hours. Using ArcGIS Version 10.3 and U.S. Census Bureau data (2018), we calculated that survey points along survey routes ranged from 0.54 to $5,945.8 \mathrm{~m}$ from the road, with the average distance being $1,423.04 \pm 72.29 \mathrm{~m}$.

\section{Behavioral Observation Field Collections}

We recorded time activity budgets during winter waterfowl surveys, between November and March of 2015 - 2016 and 2016 - 2017. We conducted surveys every other week, rotating time-location order each survey period, so that if one site was surveyed first during the first round of surveys, it would be surveyed second during the second round of surveys, and so on. We visited and recorded time activity budgets at additional non-study sites (i.e., wetlands not included in the previously described survey routes, but within the study area) when black ducks were incidentally found. We calculated activity budgets and daily energy expenditure from behavioral observations taken whenever black ducks were found during routine survey routes, or when black ducks were located opportunistically at non-survey wetlands within the study area. We performed behavioral observations during diurnal hours, between 0600 - 1800 hours (IACUC Protocol Number: 15-1104.1). We attempted to record nocturnal observations at survey points with a night vision scope between 1801 - 0559 hours, but field conditions typically did not provide adequate lighting and we were also unable to locate black ducks at study area wetlands nocturnally. We completed observations from within a vehicle when possible, or in 
nearby cover around the waterbody, and gave a 5-minute acclimation period prior to beginning behavioral observations to allow the birds to become accustomed to observer presence (McBride 2014). We recorded 10 minutes of observations per bird, recording behavioral activities every 10 seconds within the period. We recorded a single observation period for every bird present when possible. Each 10-minute observation was considered independent (Tatu et al. 2007). We used 10 behavioral activity categories: foraging, sleeping, loafing, comfort movements, swimming, selfmaintenance, agonistic, courtship, flying, and disturbance-induced (Table 2). We collected wetland location, Beaufort scale wind speed (NABBS 2018), ambient temperature $\left({ }^{\circ} \mathrm{C}\right)$, time, U.S. Weather Bureau sky condition codes (NABBS 2018), percent ice cover, percent wetland basin (i.e., waterbody surface area minus the overlapping percent vegetation area), and potential disturbances present during the survey (i.e., active hunting, predator presence, pedestrian presence, vehicular traffic, boat traffic, construction, observer-inflicted, active fishing, active food handouts, dog presence, and other), prior to beginning observation periods.

\section{Behavioral Observation Statistical Analysis}

For analysis, due to the infrequent observations of courtship ( $\mathrm{n}=36,0.1 \%$ of total observations), comfort movements ( $\mathrm{n}=368,1.1 \%$ of total observations), and agonistic $(\mathrm{n}=270,0.7 \%$ of total observations) behaviors, we collapsed these 3 behaviors into a sole "other" category for analysis. We modeled the probability of observing each behavior using multinomial logistic regression (Venables and Ripley 2002). We estimated the probability of observing each behavior with an intercept-only model. We also related the probability of observing each behavior to levels of wetland management (i.e. actively managed, passively managed, and unmanaged), wetland naturalness (i.e. modified, created, natural, riverine), wetland system (i.e. riverine, palustrine, lacustrine), and year with one model that had each 10 -second observation as a replicate sample. 
We fit models using package nnet version 7.3-12 within R version 3.3.1 (Venables and Ripley 2002, R Core Team 2017). We performed post-hoc testing of pairwise comparisons using package emmeans version 1.1.2 within $\mathrm{R}$ version 3.3.1 with a Tukey adjustment, and determined overall statistical significance at $P<0.05$ (Lenth 2018).

\section{Daily Energy Expenditure}

We measured daily energy expenditure (DEE) over a 12-hour period during the diurnal hours of 0600 - 1800 using the following equation:

$$
D E E=\sum_{i=1}^{n}\left[\left(\left(R M R \times a_{i}\right)+C T\right) \times T_{i}\right]
$$

Where $n$ is the number of behaviors being summed across, $R M R$ is equal to the resting metabolic rate (kcal/bird/hr), $a_{i}$ is equal to an activity specific multiplier, $C T$ is equal to the cost of thermoregulation ( $\mathrm{kcal} / \mathrm{bird} / \mathrm{hr})$, and $T_{i}$ is equal to the calculated raw proportion of time spent in a specific behavior from the time activity budgets (Albright et al. 1983, Cramer 2009, Jones et al. 2014, Livolsi 2015).

We estimated species-specific RMR values using values and methods from Miller and Eadie (2006). We took activity-specific multipliers $\left(a_{i}\right)$ from Wooley (1976), Wooley and Owen (1978), and Livolsi (2015) (See Appendix J). The RMR equation from Miller and Eadie (2006) is:

$$
R M R=c \times \text { Mass }^{d}
$$

In which $c(c=457)$ and $d(d=0.77)$ represent the mass proportionality coefficient and the slope of the regression line on a log scale for dabbling duck species (Cramer 2009, Jones et al. 2014, Livolsi 2015). We averaged female and male black duck mass values (1.2035 kg) from Longcore et al. (2000) with the aim of including the average mass for the overall black duck population and estimated RMR to be $527.06 \mathrm{kcal} / \mathrm{bird} / \mathrm{ha}$. To account for site-specific energetic costs, we 
calculated a complex cost of thermoregulation (CT) following procedures used in McKinney and McWilliams (2005). We incorporated temperature and the corresponding lower critical temperature (LCT) and average wind speed at each site during observations to account for temperature-dependent metabolic heat production. We estimated average wind speed by calculating the median of Beaufort Scale wind speed codes recorded during behavioral observations and converting to $\mathrm{m} / \mathrm{sec}$. Additionally, to compare the newer calculation method of DEE using a complex cost of thermoregulation to the former method of calculating DEE using a simple cost of thermoregulation (SCT), we also calculated the latter method from the equation:

$$
S C T=0.5779 \times\left(\text { LCT - Temperature } e_{\text {ambient }}\right)
$$

Where LCT is a species-specific temperature of $8^{\circ} \mathrm{C}$ (Livolsi et al. 2015a, Kendeigh et al. 1977, Wooley and Owen 1977, McKinney and McWilliams 2005, Livolsi et al. 2015a).

We then related energy expenditure from the DEE model with the complex CT component to wetland system (i.e., riverine, palustrine, lacustrine), wetland naturalness level (i.e., modified, created, natural, riverine), management scheme (i.e., actively managed, passively managed, and unmanaged), and year using a single general linear model with energy expenditure per observation as replicate samples. We then used package emmeans version 1.1.2 within program $\mathrm{R}$ version 3.3.1 to perform pairwise comparisons of daily energy expenditure calculated per individual bird observations with the complex CT component among wetland systems, levels of naturalness, year, and management scheme using a significance level of $P<$ 0.05 (Lenth 2018, R Core Team 2017). 


\section{RESULTS}

\section{Time-Activity Budgets}

We performed surveys at 141 points in the first year and increased to 203 points in the second year to increase coverage. As such, we increased the number of routes in Pennsylvania to 8 in the second year, and maintained 5 routes in West Virginia. We collected 467 10-minute behavioral observations between 2015-2017, observing 209 individuals in the first year (2015-2016) and 258 individuals in the second (2016-2017). Of these observations, only 7.3\% occurred at nonstudy, incidental sites (i.e, locations not included in the survey routes performed every other week). We recorded 74 (15.8\%) observations in November, 95 (20.3\%) in December, 175 (37.5\%) in January, 100 (21.4) in February, and 23 (4.9\%) in early March. We took 40 (9\%) of the observations in the early morning, $155(33 \%)$ in the late morning, $180(38 \%)$ in the early afternoon, and $92(20 \%)$ in the evening crepuscular hours. The average size of total mixed species flocks was 49 birds $(\mathrm{SE}=3.45$ ), with a minimum of 1 bird and a maximum count of 674 birds. The average size of black duck groups (within and separate from mixed flocks) was 12 individuals $(\mathrm{SE}=0.58)$, with a minimum of 1 black duck and a maximum of 50 black ducks.

Behavior varied by wetland management scheme, wetland system type, wetland naturalness, and year. Black ducks spent the most time swimming in lacustrine systems (35\%), followed by palustrine systems (29\%), and the least time in riverine systems (24\%; Table 3; See Appendix K). They foraged significantly more in palustrine systems than in others. They swam the most in both created (28\%) and modified (44\%) wetlands. However, black ducks foraged the most in natural wetlands (53\%) (Table 4; See Appendix L). They loafed significantly more in created wetlands, swam significantly more in modified wetlands, and foraged significantly more in natural wetlands than in others. Black ducks foraged the most across all wetland management 
schemes (passively managed $=29 \%$, actively managed $=28 \%$ ), except in unmanaged wetlands (24\%; Table 5; See Appendix M). In unmanaged wetlands, black ducks spent the largest proportion of time swimming (35\%). Black ducks spent significantly more time foraging, swimming, and in "other" behaviors in 2016-2017 than in 2015-2016, whereas they spent more time loafing, sleeping, and in self-maintenance in the first year (Table 6; See Appendix N).

\section{Daily Energy Expenditure}

We calculated a DEE value for black ducks of 1,542.95 kJ/bird/day from our equation that incorporated a complex CT component. The simple CT model resulted in a value of 684.94 $\mathrm{kJ} /$ bird/day. Black duck energy expenditure from the CCT model did not vary significantly among wetland systems, management regimes, naturalness, or by year (Table 7).

\section{DISCUSSION}

\section{Daily Energy Expenditure}

Daily energy expenditure calculations with a CCT component resulted in a higher black duck DEE on the Appalachian Plateau than reported in previous studies, which ranged between 1,176.05-1,418.04 (Livolsi 2015, Livolsi et al. 2015a; See Appendix O). Despite this, we did not find significant differences in energy expenditure across different wetland systems, naturalness, or management schemes (Table 7). As average biomass was relatively high throughout the study area at $774.2 \pm 7.9 \mathrm{~kg} / \mathrm{ha}$ (Yannuzzi Chapter 1), food availability is unlikely to be the sole driver behind wintering black duck behavior. Waterfowl activities also change in response to the thermal environment and as such, energy expenditure from behavioral activities and environmental conditions likely interacted in such a way that created balance among the different wetland systems, levels of naturalness, and management schemes (Jorde et al. 1984, Paulus 1988). 
We believe that our higher energy expenditure in this region, when compared to former estimations in black duck wintering core range, is due to several reasons. First, swimming was the overall most observed behavior from our time-energy budgets and is also one of the more energy-costly activities $\left(a_{i}=2.2\right)$. Second, our equation incorporates a higher RMR value (RMR $=527.06)$ than those that used trapped black duck average masses and previous studies that estimated RMR through respirometry studies (Hartung 1967, Berger et al. 1970, Wooley and Owen 1977, Bennett and Harvey 1987, Cramer 2009, Jones et al. 2014). Our RMR estimation follows newer methods used by Miller and Eadie (2006) and Jones et al. (2014), which uses a much larger sample size to estimate dabbling duck-specific RMR components than previously averaged RMR values (Jones et al. 2014). We further felt incorporating the mean from a wider range of masses would better represent black ducks in the Appalachian region than using masses collected from the core range of black ducks, as they are exposed to a different habitat and food composition than further inland (Mendall 1949). Third, studies have noted significant differences in diurnal and nocturnal behavior, and as such, our 12-hr diurnal energy budget is possibly somewhat overestimated than if it were a 24-hr energy budget (Jones 2012, Lancaster et al. 2015). Despite this, our calculated DEE based on a 12-hr diurnal energy budget is still higher when compared to other DEE estimations from 12-hr budgets (See Appendix O). Despite our RMR value being somewhat higher than these studies, our estimations using the CCT are only $1.2 \%$ greater than if we had incorporated the same RMR as previous studies. Additionally, when using previous studies' RMR value of $514.98 \mathrm{kcal} / \mathrm{bird} / \mathrm{ha}$, our energy expenditure remains higher than previous estimates (See Appendix P; Cramer 2009, Jones et al. 2014).

Lastly, our study area experiences frigid temperatures and high winds, likely contributing to the higher energy expenditure. This is further witnessed in the vast difference in energy 
expenditure between the simple CT equation and complex CT equation where site-specific wind speed, ambient temperature, and morphometrics are incorporated into CT (McKinney and McWilliams 2005). The complex CT model gives a DEE value that is 2.25 times higher than the simple CT model. As a result, by using the complex CT model we are able to obtain a more realistic DEE value to include in duck use day estimates. Our more accurate estimates of energy expenditure will aid in the proper estimation of available energy and habitat for wintering waterfowl so that we can make improved wetland management decisions in the Central Appalachian region.

\section{Time Activity Budgets}

Within levels of wetland naturalness, black duck behaviors varied greatly. In created wetlands, black ducks participated in activities with lower energetic costs, including loafing, selfmaintenance, and sleeping, significantly more than in modified or natural wetlands. This could be the result of created wetlands in the study area offering a higher seed biomass than modified or natural wetlands, which would mean black ducks would need to spend less time feeding to obtain adequate nutrients (Yannuzzi Chapter 1, Paulus 1988). Conversely, black ducks foraged significantly more in natural wetlands, where there was significantly lower seed biomass, and as such may have devoted more time to obtaining nutrients (Yannuzzi Chapter 1). Black ducks have been observed in the past spending $20 \%$ of their diurnal activity foraging on energy-filled corn, and that time spent feeding depended on quality of food, increasing when nutrient value was low (Brodsky and Weatherhead 1985, Paulus 1988). These behavioral differences among levels of wetland naturalness suggest that black duck behavior is linked to food type availability and as such, habitat quality. 
We found that black ducks spent the most time swimming and sleeping and the least time foraging in lacustrine habitats, which is consistent with past observations that wintering waterfowl frequently used deep water habitats during the day for loafing to escape avian predation (Tamisier 1970, Paulus 1984a, Paulus 1988). Additionally, lacustrine systems contained significantly higher biomass than any other wetland system and as such, black ducks likely did not have to spend a large amount of time foraging to meet their dietary requirements (Yannuzzi Chapter 1). Black ducks spent most of their time foraging in palustrine habitats, followed by riverine habitats. We expect this behavior in palustrine systems follows that of natural wetlands, wherein palustrine systems contained the lowest cumulative biomass, and as such, black ducks had to spend more time acquiring energy (Brodsky and Weatherhead 1985, Paulus 1988, Yannuzzi Chapter 1). However, since riverine systems contained the highest available energy when compared to lacustrine and palustrine systems, we would typically expect to see the least amount of time spent foraging in these habitats. As such, we believe that riverine systems provided a more sheltered, favorable microclimate with surrounding banks and vegetative cover than other systems, which would allow for more energy to devote to survival, including foraging, when winter conditions were particularly harsh and energy intake would be important (Albright et al. 1983, Longcore and Gibbs 1988, Paulus 1988, Yannuzzi Chapter 1). Riverine habitats in Nebraska, characterized by high, wooded banks similar to those found in West Virginia and Pennsylvania, maintained a higher temperature than surrounding ambient temperature, lower humidity levels, and better forage throughout the winter, allowing mallards to be more active overall and spend most of their time foraging while in these habitats (Jorde et al. 1984). Furthermore, during periods of heavy rain, riparian zones may make for highly nutritious foraging around riverine habitats (Stevens et al. 2003). Additionally, black ducks spent 
significantly less time sleeping in palustrine habitats than in either riverine or lacustrine habitats, allowing for more time spent in social behaviors (i.e., courtship, agonistic, and comfort movements). Despite palustrine systems containing the lowest available energy among wetland systems (Yannuzzi Chapter 1), black ducks appear to be attempting to use these lower quality habitats for food, socializing, and refugia.

Across management schemes, black ducks swam the most in unmanaged wetlands, and slept more in actively managed wetlands than in all other management types. They also foraged more in both actively and passively managed wetlands. Unmanaged wetlands, typically found to hold lower seed and invertebrate biomass than managed wetlands (Anderson and Smith 2000, Johnson 2008), surprisingly contained the highest overall biomass within management scheme categories, and held the highest macroinvertebrate biomass, as well (Yannuzzi Chapter 1). As such, we see the least amount of foraging in this habitat as black ducks do not have to work as hard to obtain nutrients (Brodsky and Weatherhead 1985, Paulus 1988).

Meanwhile, actively managed wetlands, where wetlands are drained and refilled seasonally, are generally accepted to have higher concentrations of seed and invertebrate biomass due to the provision of aerobic conditions allowing for such growth (Fredrickson and Taylor 1982, Anderson and Smith 2000). Despite this, actively managed wetlands in Appalachia fell in the middle of overall energy availability among management schemes and passively managed wetlands had the lowest food availability (Yannuzzi Chapter 1). As such, seeing the most foraging behavior in actively and passively managed wetlands is not surprising, as birds had to spend more time foraging to meet their energy requirements (Brodsky and Weatherhead 1985, Paulus 1988). 
Interestingly, black duck behavior changed significantly between year one and year two of the study. In the first year, they spent more time in low energy activities like sleeping, while in the second year they participated more in high energy activities such as feeding and other behaviors like courtship, comfort movements, and agonistic behaviors. Waterfowl and other avian species revert to energy conserving behaviors, such as sleeping, when temperatures reach below freezing (Paulus 1988, Berger and Phillips 1995, Gauthier-Clerc 2000). As such, we believe our observations are a result of black ducks trying to conserve energy in the first year when temperatures were slightly colder on average during the study period $\left(4.15^{\circ} \mathrm{C}\right.$ versus $4.72^{\circ} \mathrm{C}$ ) and had to put more energy towards thermoregulation. Physiological studies have shown that sleep in waterfowl increases when lipid and protein reserves decrease, which typically decline from mid-winter to early spring (Fox et al. 1992, Berger and Phillips 1995, GauthierClerc et al. 2000). Furthermore, past research has indicated that avian species allocate more time to sleeping, a low energy cost activity, during winter after food resources have been depleted to conserve energy (Gauthier-Clerc et al. 2000). As such, temperature plays an important part in waterfowl behavior and habitat use throughout the winter (Jorde et al. 1984).

Ultimately, black ducks appeared to be using different types of aquatic bodies for distinct purposes related to winter biomass availability and likely, microclimate. This study supports past research in that it indicates providing diverse wetland complexes is important to meeting the thermoregulatory, nutritional, social, and relief needs of wintering waterfowl (Conroy et al. 1987, Conroy et al. 1989, Osborn et al. 2017).

\section{MANAGEMENT IMPLICATIONS}

With long periods of freeze, cold temperatures, and high winds, proper management for wintering waterfowl in Central Appalachia is essential to providing the necessary nutrients for 
winter survival and spring migration to the breeding grounds. Because black duck activity varies significantly among different wetland systems, management schemes, and levels of naturalness, we recommend that wetland and waterfowl managers focus on supplying wetland complexes with a wide array of wetland and riverine systems to meet their behavioral and thermoregulatory needs throughout the winter. With winter weather and habitat variables (i.e., food abundance and quality, protection from predators, and microclimate) as drivers of wintering waterfowl behavior, focusing on providing waterfowl with many nearby wetlands and rivers to accommodate their nutritional, social, and energy conservation behaviors has shown to be important in past research (Jorde et al. 1984, Pearse et al. 2012, Osborn et al. 2017), and continues to hold true for wintering Central Appalachian black ducks.

\section{ACKNOWLEDGMENTS}

We thank J. S. Carr, M. C. McDougal, M. A. Petschauer, J. Stempka, B. Ellis, K. Jacobs, D. Dowler, T. Pratt, T. Shreve, J. McCrady, T. Hardman, J. Allison, J. Sammons, and M. L. Spindler for their involvement in fieldwork. We are also grateful to Z. Dienes, H. Warner, L. Stollings, M. Evers, S. Cua, J. Gordon, C. Rausch, and L. Leightner for their assistance in lab work. Financial support for this study was provided by the U.S. Fish and Wildlife Service through the Black Duck Joint Venture, the Pennsylvania Game Commission, the West Virginia Division of Natural Resources, and West Virginia University. J. T. Anderson was supported by the National Science Foundation under Cooperative Agreement No. OIA-1458952, the USDA National Institute of Food and Agriculture, McIntire Stennis project WVA00117, and the West Virginia Agricultural and Forestry Experiment Station during manuscript preparation. This is scientific article number xxxx of the West Virginia Agricultural and Forestry Experiment Station, Morgantown. 


\section{LITERATURE CITED}

Albright, J. J., R. B. Owen, Jr., P. O. Corr. 1983. The effects of winter weather on the behavior and energy reserves of black ducks in Maine. Transactions of the Northeast Section of the Wildlife Society 40:118-128.

American Black Duck Adaptive Harvest Management Working Group [ABDAHMWG]. 2017. American black duck changes in hunting regulations 2017-18. Atlantic Flyway Council \& Mississippi Flyway Council. <https://www.dec.ny.gov/>. Accessed 6 April 2017.

Anderson, J. T. and L. M. Smith. 2000. Invertebrate response to moist-soil management of playa wetlands. Ecological Applications 10:550-558.

Balcombe, C. K., J. T. Anderson, R. H. Fortney, and W. S. Kordek. 2005a. Wildlife use of mitigation and reference wetlands in West Virginia. Ecological Engineering 25:85-99.

Balcombe, C. K., J. T. Anderson, R. H. Fortney, and W. S. Kordek. 2005b. Aquatic macroinvertebrate assemblages in mitigated and natural wetlands. Hydrobiologia $541: 175-188$.

Baldassarre, G. 2014. Ducks, geese, and swans of North America. Revised and updated edition. Johns Hopkins University Press, Baltimore, Maryland, USA.

Bennett, P. M. and P. H. Harvey. 1987. Active and resting metabolism in birds: allometry, phylogeny, and ecology. Journal of Zoology, London 213:327-363.

Bergan, J. F. and L. M. Smith. 1989. Differential habitat use by diving ducks wintering in South Carolina. Journal of Wildlife Management 53:1117-1126.

Berger, R. J. and N. H. Phillips. 1995. Energy conservation and sleep. Behavioural brain research 69:65-773. 
Berger, M., J. S. Hart, and O. Z. Roy. 1970. Respiration, oxygen consumption, and heart rate in some birds during rest and flight. Zeitschrift fur Vergleichende Physiologie 66:201-214.

Blandin, W. W. 1992. Population characteristics and simulation: modeling of black ducks. U.S. Fish and Wildlife Service Fish and Wildlife Research 11.

Brodsky, L. M. and P. J. Weatherhead. 1985. Time and energy constraints on courtship in wintering American black ducks. Condor 87:33-36.

Calder, W. A. and J. King. 1974. Thermal and calorific relations of birds. Avian Biology 4:259413.

Clipp, H. L., M. L. Peters, and J. T. Anderson. 2017. Winter waterbird community composition and use at created wetlands in West Virginia, USA. Scientifica 17:1-13.

Cole, C. A. and R. P. Brooks. 2000. A comparison of the hydrologic characteristics of natural and created mainstem floodplain wetlands in Pennsylvania. Ecological Engineering $14: 221-231$.

Conroy, M. J., G. R. Costanzo, and D. B. Stotts. 1987. Winter movements of American black ducks in relation to natural and impounded wetlands in New Jersey. Pages $31-45$ in Whitman, W. R., and W. H. Meredith. (eds.) Waterfowl and wetlands symposium: proceedings of a symposium on waterfowl and wetlands management in the coastal zone of the Atlantic flyway. Delaware Department of Natural Resources and Environmental Control, Dover, Delaware, USA.

Conroy, M. J., G. R. Costanzo, and D. B. Stotts. 1989. Winter survival of female American black ducks on the Atlantic coast. Journal of Wildlife Management 53:99-109.

Conroy, M. J., M. W. Miller, and J. E. Hines. 2002. Identification and synthetic modeling of factors affecting American black duck populations. Wildlife Monographs 150:1-64. 
Costanzo, G. R. and R. A. Malecki. 1989. Foods of black ducks along coastal New Jersey. Dissertation, Cornell University, Ithaca, NY, USA.

Cramer, D. M. 2009. Estimating habitat carrying capacity for American black ducks wintering in southern New Jersey. Thesis, University of Delaware, Newark, USA.

Cramer, D. M., P. M. Castelli, T. Yerkes, and C. K. Williams. 2012. Food resource availability for American black ducks wintering in southern New Jersey. Journal of Wildlife Management 76:214-219.

Dahl, T. E. 1990. Wetlands losses in the United States 1780's to 1980's. U.S. Department of the Interior, Fish and Wildlife Service, Washington, D.C.

Dahl, T. E., C. E. Johnson, and W. E. Frayer. 1991. Wetlands status and trends in the conterminous United States mid-1970’s to mid-1980’s. U.S. Department of the Interior, Fish and Wildlife Service, Washington, D.C.

Dahl, T. E. 2000. Status and trends of wetlands in the conterminous United States 1986 to 1997. U.S. Department of the Interior, Fish and Wildlife Service, Washington, D.C.

Dahl, T. E. 2011. Status and trends of wetlands in the conterminous United States 2004 to 2009. U.S. Department of the Interior; Fish and Wildlife Service, Washington, D.C.

Fino, S. R., C. K. Williams, M. C. Livolsi, K. M. Ringelman, J. M. Coluccy, P. K. Devers, P. M. Castelli. 2017. Carrying capacity of wintering American black ducks in forested wetlands. Journal of Wildlife Management 81:943-950.

Fox, A. D., R. King, and J. Watkin. 1992. Seasonal variation in weight, body measurements and condition of free-living Teal. Bird Study 39:53-62. 
Francis, C. M., J. R. Sauer, and J. R. Serie. 1998. Effect of restrictive harvest regulations on survival and recovery rates of black ducks. Journal of Wildlife Management 62:15441557.

Fredrickson, L. H., and T. S. Taylor. 1982. Management of seasonally flooded impoundments for wildlife. US Department of Interior, Fish and Wildlife Service. Resource Publication no. 148 .

Gauthier-Clerc, M., A. Tamisier, and F. Cézilly. 2000. Sleep-vigilance trade-off in gadwall during the winter period. Condor 102:307-313.

Hartung, R. 1967. Energy metabolism in oil-covered ducks. Journal of Wildlife Management $31: 798-804$.

Johnson, A. M. 2008. Food abundance and energetic carrying capacity for wintering waterfowl in the Great Salt Lake wetlands. Thesis, Oregon State University, Corvallis, USA.

Jones, III, O.E. 2012. Constructing a 24 hour time-energy budget for American black ducks wintering in coastal New Jersey. Thesis, University of Delaware, Newark, USA.

Jones, III, O. E., C. K. Williams, and Castelli P. M. 2014. A 24-hour time-energy budget for wintering American black ducks (Anas rubripes) and its comparison to allometric estimations. Waterbirds 37:264-273.

Jorde, D. G., G. L. Krapu, R. D. Crawford, and M. A. Hay. 1984. Effects of weather on habitat selection and behavior of mallards wintering in Nebraska. Condor 86:258-265.

Kendeigh, S. C., V. R. Dol'nik, and V. M. Gavrilov. 1977. Avian energetics. Pages 127-204 in Granivorous birds in ecosystems: their evolution, populations, energetics, adaptations, impact, and control (J. Pinowski and S. C. Kendeigh, Eds.). Cambridge University Press, New York. 
Kloskowski, J., A. J. Green, M. Polak, J. Bustamante, and J. Krogulec. 2009. Complementary use of natural and artificial wetlands by waterbirds wintering in Donana, south-west Spain. Aquatic Conservation: Marine and Freshwater Ecosystems 19:815-826.

Kross, J., R. M. Kaminski, K. J. Reinecke, E. J. Penny, and A. T. Pearse. 2008. Moist-soil seed abundance in managed wetlands in the Mississippi Alluvial Valley. Journal of Wildlife Management 72:707-714.

Lancaster, J. D., J. B. Davis, R. M. Kaminski, A. D. Afton, and E. J. Penny. 2015. Mallard use of a managed public hunting area in Mississippi. Journal of Southeastern Association of Fish and Wildlife Agencies 2:281-287.

Lenth, R. 2018. emmeans: Estimated Marginal Means, aka Least-Squares Means. R package version 1.1.2. <https://CRAN.R-project.org/package=emmeans>.

Livolsi, M. C., K. M. Ringelman, and C. K. Williams. 2014. Subsampling reduces sorting effort for waterfowl foods in salt-marsh core samples. Journal of Fish and Wildlife Management 5:380-386.

Livolsi, M. C. 2015. Bioenergetics, behavior, and sea level rise: current status and future implications for wintering dabbling ducks in Delaware. Thesis, University of Delaware, Newark, USA.

Livolsi, M. C., C. K. Williams, J. M. Coluccy, and M. T. DiBona. 2015a. Morphometrics of midAtlantic dabbling ducks for use in thermoregulation models. Condor 117:644-649.

Livolsi, M. C., K. M. Ringelman, J. M. Coluccy, M. T. DiBona, and C. K. Williams. $2015 b$. Implications of uncertainty in true metabolizable energy estimates for estimating wintering waterfowl carrying capacities. Wildlife Society Bulletin 39:827-833. 
Longcore, J. R. and J. P. Gibbs. 1988. Distribution and numbers of American black ducks along the Maine coast during the severe winter of 1980-1981. Pages 377-389 in M. W. Weller, ed. Waterfowl in winter symposium. Univ. Minnesota Press, Minneapolis.

Longcore, J. R., D. G. McAuley, G. R. Hepp, and J. M. Rhymer. 2000. American black duck (Anas rubripes). Cornell Lab of Ornithology: Birds of North America. <https://birdsna.org/Species-Account/bna/species/ambduc/>. Accessed 1 Oct 2016.

McBride, K. M. 2014. Three techniques for attaching solar-powered GSM satellite transmitters on surf scoters. Thesis, University of Maryland, College Park, USA.

McClanahan, M. D. 2015. Habitat use and response to wetland management practices of nonbreeding dabbling ducks in western Tennessee. Thesis, University of Tennessee, Knoxville, USA.

McKinney, R. A. and S. R. McWilliams. 2005. A new model to estimate daily energy expenditure for wintering waterfowl. Wilson Bulletin 11:744-55.

Mendall, H. L. 1949. Food habitats in relation to black duck management in Maine. Journal of Wildlife Management 13:64-101.

Miller, M. R., and J. M. Eadie. 2006. The allometric relationship between resting metabolic rate and body mass in wild waterfowl (Anatidae) and an application to estimation of winter habitat requirements. Condor 108:166-177.

Morton, J. M., A. C. Fowler, and R. L. Kirkpatrick. 1989. Time and energy budgets of American black ducks in winter. Journal of Wildlife Management 53:401-410.

National Audubon Society. 2010. The Christmas bird count historical results [online]. <http://www.christmasbirdcount.org>. Accessed 1 Oct 2016. 
National Centers for Environmental Information [NCEI]. 2017. Monthly summaries map. NCEI Map Application version 1.8.4. U.S. Department of Commerce, National Oceanic and Atmospheric Administration, Asheville, NC. <https://gis.ncdc.noaa.gov/maps/ncei/summaries/monthly>. Accessed 1 July 2018.

Newcomb, K. C. 2014. Survival and habitat selection of American black ducks in Tennessee. Thesis, Mississippi State University, Starkville, USA.

Newcomb, K. C., J. B. Davis, R. M. Kaminski, and M. J. Gray. 2015. Winter survival of female American black ducks in Tennessee, USA. Condor 118:33-45.

Nichols, J. D. 1991. Science, population ecology, and the management of the American black duck. Journal of Wildlife Management 55:790-799.

North American Breeding Bird Survey [NABBS]. 2018. Weather codes. U.S. Geological Survey Patuxent Wildlife Research Center. < https://www.pwrc.usgs.gov/BBS/>. Accessed 15 Sept 2016.

O’Connor, J. L. 2016. The foraging habits and resultant functional response of American black ducks. Thesis, University of Maryland, College Park, USA.

Osborn, J. M., H. M. Hagy, M. D. McClanahan, J. B. Davis, and M. J. Gray. 2017. Habitat selection and activities of dabbling ducks during non-breeding periods. Journal of Wildlife Management 81:1482-1493.

Paulus, S. L. 1984a. Activity budgets of nonbreeding gadwalls in Louisiana. Journal of Wildlife Management 48:371-380.

Paulus, S. L. 1984b. Molts and plumages of gadwalls in winter. Auk 101:887-889.

Paulus, S. L. 1988. Time-activity budgets of nonbreeding Anatidae: a review. Pages 135-152 in M. W. Weller, ed. Waterfowl in winter symposium. Univ. Minnesota Press, Minneapolis. 
Pearse, A. T., R. M. Kaminski, K. J. Reinecke, and S. J. Dinsmore. 2012. Local and landscape associations between wintering dabbling ducks and wetland complexes in Mississippi. Wetlands 32:859-869.

Pennsylvania Department of Conservation and Natural Resources [PADCNR]. 2000. Landforms of Pennsylvania. Commonwealth of Pennsylvania Department of Conservation and Natural Resources Bureau of Topographic and Geologic Survey. <http://www.denr.state.pa.us/topogeo>. Accessed 4 Oct 2016.

Pennsylvania State University [PSU]. 2016. The Pennsylvania state climatologist: regional data. Pennsylvania State Climate Office, University Park, PA. <http://climate.psu.edu/data/>. Accessed 4 Oct 2016.

Plattner, D. M., M. W. Eichholz, and T. Yerkes. 2010. Food resources for wintering and spring staging black ducks. Journal of Wildlife Management 74:1554-1558.

R Core Team. 2017. R: A language and environment for statistical computing. R Foundation for Statistical Computing, Vienna, Austria.

Reinecke, K. J., R. M. Kaminski, D. J. Moorhead, J. D. Hodges, and J. R. Nassar. 1989. Mississippi Alluvial Valley. Pages 203-247 in L.M. Smith, R.L. Pederson, and R.M. Kaminski, editors. Habitat management for migrating and wintering waterfowl in North America. Texas Tech University Press, Lubbock, TX.

Ringelman, K. M., C. K. Williams, P. K. Devers, J. M. Coluccy, P. M. Castelli, K. A. Anderson, J. L. Bowman, G. R. Costanzo, D. M. Cramer, M. T. DiBona, M. W. Eichholz, M. Huang, B. Lewis, Jr., D. M. Plattner, and T. Yerkes. 2015. A meta-analysis of American black duck winter habitat use along the Atlantic coast. Journal of Wildlife Management 79:1298-1307. 
Sevon, W. D. 2000. Physiographic provinces of Pennsylvania. 4th ed. Pennsylvania Department of Conservation and Natural Resources, Bureau of Topographic and Geologic Survey.

Stevens, C. E., T. S. Gabor, and A. W. Diamond. 2003. Use of restored small wetlands by breeding waterfowl in Prince Edward Island, Canada. Restoration Ecology 11:3-12.

Tamisier, A. 1970. Signification du grégarisme diurne et de l'alimentation nocturne des Sarcelles d'hiver Anas c. crecca L. Terre et Vie 24:511-562.

Tatu, K. S., J. T. Anderson, L. J. Hindman, and G. Seidel. 2007. Diurnal foraging activities of mute swans in Chesapeake Bay, Maryland. Waterbirds 30:121-128.

U.S. Census Bureau. 2018. Geography: maps \& data. U.S. Census Bureau, U.S. Department of Commerce, Washington, D.C., USA.

U.S. Fish and Wildlife Service [USFWS]. 2014. Waterfowl population status, 2014. U.S. Department of the Interior, Washington, D.C., USA.

U.S. Fish and Wildlife Service [USFWS]. 2015. National Wetlands Inventory. U.S. Department of the Interior, U.S. Fish and Wildlife Service, Washington, D.C. <http://www.fws.gov/wetlands/>. Accessed 20 September 2016.

Venables, W. N. and B. D. Ripley. 2002. Modern Applied Statistics with S. Fourth Edition. Springer, New York.

Veselka, W., IV, J. T. Anderson, and W. S. Kordek. 2010. Using dual classifications in the development of avian wetland indices of biological integrity for wetlands in West Virginia, USA. Environmental Monitoring and Assessment 154:533-548.

Vonbank, J. A., H. H. Hagy, and A. F. Casper. 2016. Energetic carrying capacity of riverine and connected wetlands of the Upper Illinois River for fall-migrating waterfowl. American Midland Naturalist 176:210-221. 
Welsh, P. O., C. A. Paszkowski, and K. B. Tierney. 2017. Mallards (Anas platyrhynchos) and wastewater ponds, part i: mallard ducks overwintering at a northern wastewater treatment pond. Ecotoxicology and Environmental Safety 143:330-335.

West Virginia Geological \& Economic Survey [WVGES]. 2015. Physiographic Provinces of West Virginia. West Virginia Geological \& Economic Survey. <http://www.wvgs.wvnet.edu/www/geology/geolphyp.htm>. Accessed 1 Oct 2016.

Wolf, B. O. and G. E. Walsberg. 1996. Thermal effects of radiation and wind on a small bird and implications for microsite selection. Ecology 77:2228-2236.

Wooley, Jr., J. B. 1976. Energy expenditure of the black duck under controlled and free-living conditions. Thesis, University of Maine, Orono, USA.

Wooley, Jr., J. B. and R. B. Owen, Jr. 1977. Metabolic rates and heart rate-metabolism relationships in the black duck (Anas rubripes). Comparative Biochemistry and Physiology Part A: Physiology 57:363-367.

Wooley, Jr., J. B. and R. B. Owen, Jr. 1978. Energy costs of activity and daily energy expenditure in the black duck. Journal of Wildlife Management 42:739-745.

Associate Editor: 


\section{TABLES AND FIGURES}

Figure 1. Study area and survey sites used for collecting time activity budgets of wintering American black ducks in western Pennsylvania and north-central West Virginia, November March 2015 - 2016 and 2016 - 2017.

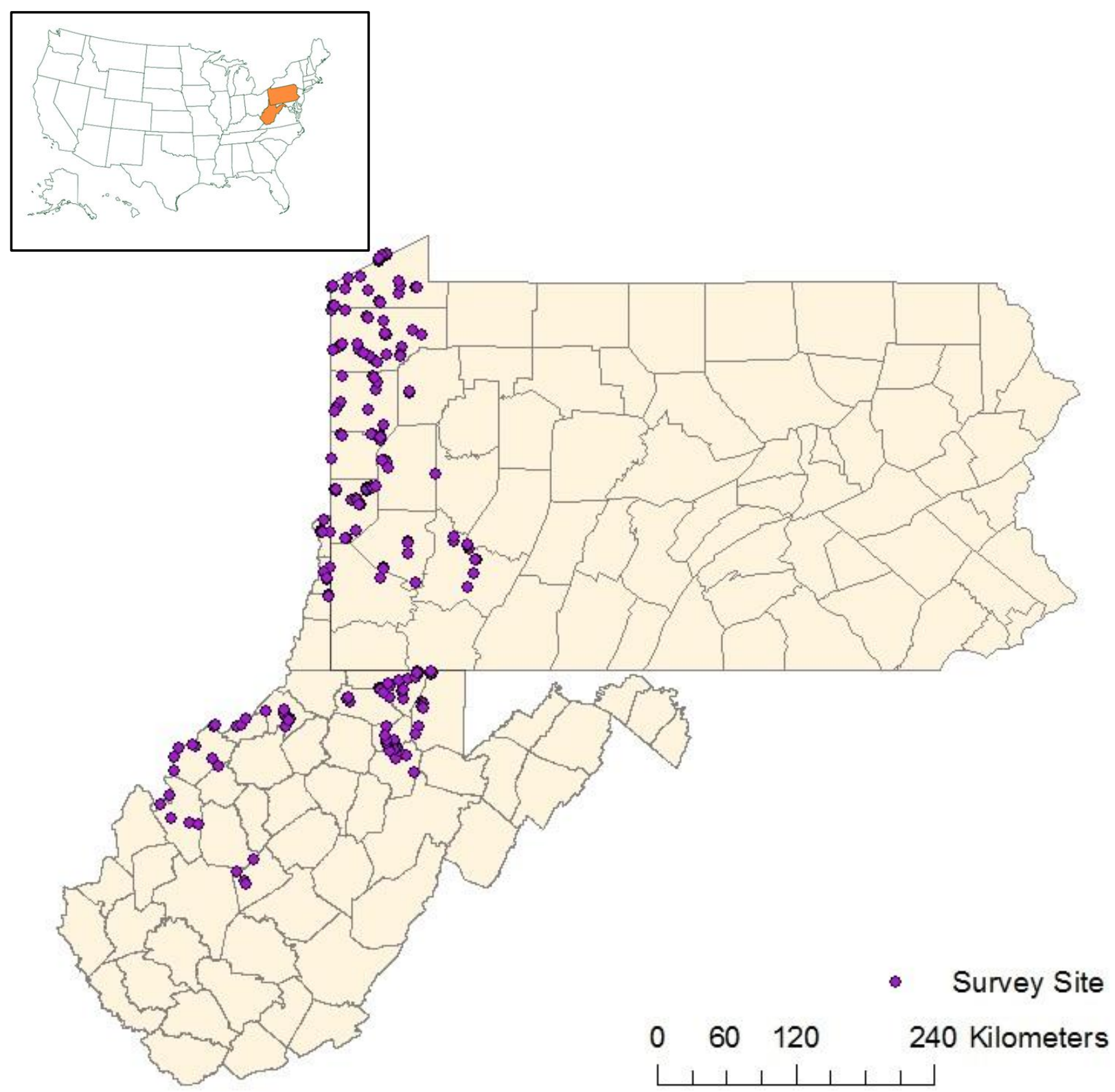


Table 1. Criteria for levels of wetland naturalness and wetland management schemes used for time activity budgets of wintering American black ducks in western Pennsylvania and northcentral West Virginia, November - March 2015 - 2016 and 2016 - 2017 (USEPA 2016).

Wetland Modifier

Definition

Level of wetland naturalness

Created

A developed wetland that did not previously exist on an upland or deep water site; excavated.

Modified

A wetland site manipulated for one or more specific functions that changes the wetland's role.

Natural

A self-regulating wetland that is integrated ecologically with its surrounding landscape.

Wetland management scheme

Actively managed

A wetland that has some type of water control device to manipulate water levels within the wetland basin.

Passively managed

A wetland that is managed solely around the wetland basin, through cutting, mowing, burning, and planting.

Unmanaged

A wetland that has no human-induced management. 
Table 2. Waterfowl behaviors used for time activity budgets of wintering American black ducks in western Pennsylvania and north-central West Virginia, November - March 2015 - 2016 and $2016-2017$.

\begin{tabular}{|c|c|}
\hline Behavior & Definition \\
\hline Foraging & $\begin{array}{l}\text { Feeding by gleaning food items off the surface, by putting head or head and } \\
\text { neck under the water, by tipping up or by diving. }\end{array}$ \\
\hline Loafing & Resting or standing still on land with eyes open, not sleeping. \\
\hline Sleeping & With the head turned and tucked between the wings. \\
\hline Swimming & Not disturbance-induced; Directional movement through water. \\
\hline $\begin{array}{l}\text { Self- } \\
\text { maintenance }\end{array}$ & $\begin{array}{l}\text { Preening recognized by the bird collecting oil from the oil gland at the base } \\
\text { of the tail and spreading it across feathers. }\end{array}$ \\
\hline $\begin{array}{l}\text { Comfort } \\
\text { movements }\end{array}$ & Stretching behaviors, wing-flapping, bathing. \\
\hline Agonistic & Aggressive behavior directed at another individual or group. \\
\hline Courtship & Head bobbing, circling, copulation. \\
\hline Flying & $\begin{array}{l}\text { Arriving at or leaving a wetland, or flying from one part of the wetland to } \\
\text { another unrelated to any disturbances. }\end{array}$ \\
\hline $\begin{array}{l}\text { Disturbance- } \\
\text { induced }\end{array}$ & Responsive, directional movement away from a disturbance. \\
\hline
\end{tabular}


Table 3. Average predicted probabilities and standard errors from multinomial models of American black duck diurnal time-activity budgets among wetland systems in western Pennsylvania and north-central West Virginia in November - March of 2015 - 2016 and 2016 2017.

\begin{tabular}{|c|c|c|c|c|c|c|}
\hline \multirow[b]{3}{*}{ Behavior } & \multicolumn{6}{|c|}{ Wetland System ${ }^{\mathrm{a}}$} \\
\hline & \multicolumn{2}{|c|}{ Lacustrine } & \multicolumn{2}{|c|}{ Palustrine } & \multicolumn{2}{|c|}{ Riverine } \\
\hline & $\bar{x}(\%)$ & SE & $\bar{x}(\%)$ & SE & $\bar{x}(\%)$ & SE \\
\hline Disturbance-induced & $0.28 \mathrm{~A}$ & 0.09 & $0.60 \mathrm{~A}$ & 0.11 & $0.29 \mathrm{~A}$ & 0.10 \\
\hline Flying & $0.76 \mathrm{~A}$ & 0.26 & $0.79 \mathrm{~A}$ & 0.29 & $0.53 \mathrm{~A}$ & 0.25 \\
\hline Foraging & $22.61 \mathrm{C}$ & 0.64 & $31.26 \mathrm{~A}$ & 0.47 & $26.68 \mathrm{~B}$ & 0.60 \\
\hline Loafing & $7.58 \mathrm{C}$ & 0.47 & $16.58 \mathrm{~B}$ & 0.49 & $23.52 \mathrm{~A}$ & 0.95 \\
\hline Other $^{\mathrm{b}}$ & $0.35 \mathrm{~B}$ & 0.11 & $1.59 \mathrm{~A}$ & 0.16 & $1.81 \mathrm{~A}$ & 0.28 \\
\hline Self-maintenance & $7.21 \mathrm{~A}$ & 0.54 & $7.43 \mathrm{~A}$ & 0.30 & $6.94 \mathrm{~A}$ & 0.54 \\
\hline Sleep & $26.20 \mathrm{~A}$ & 0.80 & $12.51 \mathrm{C}$ & 0.38 & $15.72 \mathrm{~B}$ & 0.67 \\
\hline Swim & $35.01 \mathrm{~A}$ & 0.83 & $29.25 \mathrm{~B}$ & 0.57 & $24.49 \mathrm{C}$ & 0.79 \\
\hline
\end{tabular}

${ }^{\mathrm{a}}$ Means followed by the same uppercase letter across rows are not different from each other $(P>$ $0.05)$.

${ }^{\mathrm{b}}$ Other is comprised of courtship, agonistic, and comfort movement behaviors. 
Table 4. Average predicted probabilities and standard errors from multinomial models of American black duck diurnal time-activity budgets among levels of wetland naturalness in western Pennsylvania and north-central West Virginia in November - March of 2015 - 2016 and $2016-2017$.

\begin{tabular}{|c|c|c|c|c|c|c|}
\hline \multirow[b]{3}{*}{ Behavior } & \multicolumn{6}{|c|}{ Wetland Naturalness ${ }^{\mathrm{a}}$} \\
\hline & \multicolumn{2}{|c|}{ Created } & \multicolumn{2}{|c|}{ Modified } & \multicolumn{2}{|c|}{ Natural } \\
\hline & $\bar{x}(\%)$ & SE & $\bar{x}(\%)$ & SE & $\bar{x}(\%)$ & SE \\
\hline $\begin{array}{l}\text { Disturbance- } \\
\text { induced }\end{array}$ & $0.46 \mathrm{~A}$ & 0.16 & $0.29 \mathrm{~A}$ & 0.07 & $0.42 \mathrm{~A}$ & 0.09 \\
\hline Flying & $1.11 \mathrm{AB}$ & 0.54 & $0.79 \mathrm{~A}$ & 0.20 & $0.18 \mathrm{~B}$ & 0.05 \\
\hline Foraging & $12.17 \mathrm{C}$ & 0.60 & $14.98 \mathrm{~B}$ & 0.34 & $53.40 \mathrm{~A}$ & 0.76 \\
\hline Loafing & $25.15 \mathrm{~A}$ & 1.09 & $13.90 \mathrm{~B}$ & 0.44 & $8.62 \mathrm{C}$ & 0.38 \\
\hline Other ${ }^{\mathrm{b}}$ & $1.56 \mathrm{~A}$ & 0.27 & $1.26 \mathrm{~A}$ & 0.14 & $0.94 \mathrm{~A}$ & 0.13 \\
\hline $\begin{array}{l}\text { Self- } \\
\text { maintenance }\end{array}$ & $10.30 \mathrm{~A}$ & 0.70 & $5.60 \mathrm{~B}$ & 0.26 & $5.68 \mathrm{~B}$ & 0.31 \\
\hline Sleep & $21.68 \mathrm{~A}$ & 0.96 & $18.93 \mathrm{~B}$ & 0.42 & $13.82 \mathrm{C}$ & 0.55 \\
\hline Swim & $27.55 \mathrm{~B}$ & 1.03 & $44.26 \mathrm{~A}$ & 0.61 & $16.93 \mathrm{C}$ & 0.54 \\
\hline
\end{tabular}

${ }^{a} \mathrm{Means}$ followed by the same uppercase letter across rows are not significantly different from each other $(P>0.05)$.

${ }^{\mathrm{b}}$ Other is comprised of courtship, agonistic, and comfort movement behaviors. 
Table 5. Average predicted probabilities and standard errors from multinomial models of American black duck diurnal time-activity budgets by wetland management schemes in western Pennsylvania and north-central West Virginia in November - March of 2015 - 2016 and 2016 2017.

\begin{tabular}{|c|c|c|c|c|c|c|}
\hline \multirow[b]{3}{*}{ Behavior } & \multicolumn{6}{|c|}{ Wetland Management Scheme ${ }^{a}$} \\
\hline & \multicolumn{2}{|c|}{$\begin{array}{l}\text { Actively } \\
\text { Managed }\end{array}$} & \multicolumn{2}{|c|}{ Passively Managed } & \multicolumn{2}{|c|}{ Unmanaged } \\
\hline & $\bar{x}(\%)$ & SE & $\bar{x}(\%)$ & SE & $\bar{x}(\%)$ & SE \\
\hline $\begin{array}{l}\text { Disturbance- } \\
\text { induced }\end{array}$ & $0.41 \mathrm{~A}$ & 0.10 & $0.18 \mathrm{~A}$ & 0.05 & $0.59 \mathrm{~A}$ & 0.18 \\
\hline Flying & $0.23 \mathrm{~B}$ & 0.06 & $0.06 \mathrm{C}$ & 0.03 & $1.79 \mathrm{~A}$ & 0.60 \\
\hline Foraging & $28.26 \mathrm{~A}$ & 0.66 & $28.61 \mathrm{~A}$ & 0.51 & $23.68 \mathrm{~B}$ & 0.79 \\
\hline Loafing & $15.87 \mathrm{~A}$ & 0.50 & $13.76 \mathrm{~B}$ & 0.52 & $18.05 \mathrm{~A}$ & 1.01 \\
\hline Other $^{b}$ & $1.23 \mathrm{~A}$ & 0.16 & $1.14 \mathrm{~A}$ & 0.14 & $1.39 \mathrm{~A}$ & 0.28 \\
\hline $\begin{array}{l}\text { Self- } \\
\text { maintenance }\end{array}$ & $4.18 \mathrm{C}$ & 0.27 & $10.93 \mathrm{~A}$ & 0.51 & $6.46 \mathrm{~B}$ & 0.55 \\
\hline Sleep & $22.52 \mathrm{~A}$ & 0.60 & $19.02 \mathrm{~B}$ & 0.67 & $12.89 \mathrm{C}$ & 0.69 \\
\hline Swim & $27.29 \mathrm{~B}$ & 0.58 & $26.30 \mathrm{~B}$ & 0.67 & $35.16 \mathrm{~A}$ & 1.06 \\
\hline
\end{tabular}

${ }^{\mathrm{a}}$ Means followed by the same uppercase letter across rows are not significantly different from each other $(P>0.05)$.

${ }^{\mathrm{b}}$ Other is comprised of courtship, agonistic, and comfort movement behaviors. 
Table 6. Average predicted probabilities and standard errors from multinomial models of American black duck diurnal time-activity budgets between survey years in western Pennsylvania and north-central West Virginia in November - March of 2015 - 2016 and 2016 2017.

\begin{tabular}{lccccc}
\hline & \multicolumn{4}{c}{ Survey Year $^{\mathrm{a}}$} \\
\cline { 2 - 3 } Behavior & \multicolumn{3}{c}{$2015-2016$} & \multicolumn{2}{c}{$2016-2017$} \\
\cline { 2 - 3 } & $\bar{x}(\%)$ & $\mathrm{SE}$ & $\bar{x}(\%)$ & $\mathrm{SE}$ \\
\hline Disturbance-induced & $0.37 \mathrm{~A}$ & 0.08 & $0.42 \mathrm{~A}$ & 0.08 \\
Flying & $0.74 \mathrm{~A}$ & 0.24 & $0.65 \mathrm{~A}$ & 0.22 \\
Foraging & $21.96 \mathrm{~B}$ & 0.37 & $31.73 \mathrm{~A}$ & 0.47 \\
Loafing & $17.59 \mathrm{~A}$ & 0.53 & $14.20 \mathrm{~B}$ & 0.48 \\
Other & $0.75 \mathrm{~B}$ & 0.10 & $1.75 \mathrm{~A}$ & 0.18 \\
Self-maintenance & $10.17 \mathrm{~A}$ & 0.41 & $4.21 \mathrm{~B}$ & 0.23 \\
Sleep & $20.87 \mathrm{~A}$ & 0.48 & $15.42 \mathrm{~B}$ & 0.46 \\
Swim & $27.50 \mathrm{~B}$ & 0.51 & $31.67 \mathrm{~A}$ & 0.57 \\
\hline
\end{tabular}

${ }^{a}$ Means followed by the same uppercase letter across rows are not significantly different from each other $(P>0.05)$.

${ }^{\mathrm{b}}$ Other is comprised of courtship, agonistic, and comfort movement behaviors. 
Table 7. Average daily energy expenditure calculated using a complex cost of thermoregulation component of American black ducks by wetland system, management schemes, level of naturalness, and year in western Pennsylvania and north-central West Virginia in November March of 2015 - 2016 and 2016-2017. Means are not significantly different from each other within each group $(P>0.05)$.

\begin{tabular}{rrr}
\hline & \multicolumn{2}{c}{ Daily Energy Expenditure } \\
\cline { 2 - 3 } Variable & $\bar{x}(\mathrm{~kJ} / \mathrm{bird} / \mathrm{day})$ & $\mathrm{SE}$ \\
\hline System & & \\
Lacustrine & $1,714.60$ & 250.31 \\
Palustrine & $1,788.59$ & 177.18 \\
Riverine & $1,328.05$ & 262.50 \\
Naturalness & & \\
Created & $1,712.45$ & 317.86 \\
Modified & $1,229.69$ & 162.62 \\
Natural & $1,889.11$ & 229.18 \\
Management & & \\
Active & $2,061.12$ & 213.60 \\
Passive & $1,587.07$ & 219.41 \\
Unmanaged & $1,183.06$ & 292.41 \\
Year & & 160.58 \\
2015-16 & $1,640.59$ & 164.14 \\
2016-17 & $1,580.24$ & 180.5 \\
\hline
\end{tabular}




\section{Chapter 3: Wintering American Black Duck Habitat Use on the Appalachian Plateau}

ABSTRACT American black ducks (Anas rubripes) have been in decline for over half a century due to habitat loss and degradation, and hybridization with mallards (A. platyrhyncos). While the overall population of black ducks has stabilized and even increased in portions of its range, important wintering areas in Central Appalachia have continued to see a decline. Our objective was to determine black duck and mallard use of created and natural wetlands and riverine systems, and to determine important factors influencing both black duck and mallard winter abundance to create models that could be used to guide future management practices that could contribute to meeting the North American Waterfowl Management Plan's population goal of 640,000 breeding black ducks. We performed waterfowl surveys every other week between November and March 2015-2016 and 2016-2017 in Pennsylvania and West Virginia. Black duck occupancy decreased between years, and habitat use overall was higher in passively managed wetlands, palustrine systems, and modified wetlands. Black duck abundance was lower in the second year of the study, higher in riverine and palustrine systems, modified wetlands, passively managed wetlands, and when there was an active beaver presence (Castor canadensis). Black duck abundance was also positively associated with wetland size, surrounding barren land, herbaceous land, forested land, cultivated cropland, and wetland within $200 \mathrm{~m}$ of a survey point, and negatively associated with surrounding hay or pasture land within $200 \mathrm{~m}$ of a survey point. Meanwhile, mallard occupancy was solely positively associated with surrounding developed land use within $200 \mathrm{~m}$ of a survey point. However, mallard abundance was positively associated with wetland size, and open water, developed land, barren land, forested land, hay or pasture land, wetland, and cultivated cropland within $200 \mathrm{~m}$ of a survey point. Mallard abundance was also highest in actively managed wetlands, palustrine systems, created wetlands, and on private land. Our results will help guide state and federal decisions for the management of wintering 
black ducks in Central Appalachia by providing a guideline of focal habitats and management schemes that our research has shown to be important to black ducks.

KEY WORDS Anas rubripes, Anas platyrhynchos, competition, mallard, management, occupancy, Pennsylvania, waterfowl, wintering, West Virginia

American black ducks (Anas rubripes; hereafter, black ducks) are monomorphic dabbling ducks endemic to northeastern North America (Longcore et al. 2000, Baldassarre 2014). Like many species with a restricted range, their populations have declined. They have been documented as in decline since the 1950s, with an overall population reduction of approximately 50\% (Conroy et al. 1989, USFWS 2014). Once considered the most abundant dabbling duck in northeastern North America (Longcore et al. 2000), this significant decline led to increased research on wetland habitat quality and use, the competition and hybridization with the black duck's genetically close, generalist relative, the mallard (A. platyrhynchos), and migration phenology throughout both the species' breeding and wintering ranges. This effort has helped direct management efforts towards stabilizing black duck numbers in most parts of its core range in the Atlantic Flyway; however, little research has been done in the western reaches of the Atlantic Flyway and eastern part of the Mississippi Flyway comprising Central Appalachia, where numbers are still in decline (National Audubon Society 2010).Vital information is still needed for this range, including determining wintering habitat needs and use of both black ducks and mallards.

Prior to the 1900s, breeding mallards were only found in central and western North America (Heusmann 1974, Brodsky and Weatherhead 1984). Hunting-related releases of captive game farm birds induced range expansion of the species to incorporate much of North America, including the northeast where the formerly genetically isolated black duck resides, from North 
Carolina northward through Quebec (Heusmann 1974, Brodsky and Weatherhead 1984, Ankney et al. 1987, Drilling et al. 2002). This resulted in mallard population growths such as a $600 \%$ increase in Southern Ontario between 1951 and 1971, followed by another 51\% increase between 1971 and 1985 (Collins 1974, Ankney et al. 1987). With large rises in mallards, and nation-wide decreases in and degradation of wetland habitat (Dahl 2011), including the black duck's breeding and wintering areas, the species' population declined (Ankney et al. 1987). As such, it is often in contention if the seeping of the mallard into black duck territory has created competition for habitat.

In a recent wintering mid-Atlantic study, Ringelman et al. (2015) believed black ducks were using less energetically productive saltmarsh habitats in avoidance of competition with mallards and to aid in keeping a smaller home range, resulting in niche separation. Competition on the breeding grounds has been documented on several occasions (Merendino et al. 1993, Conroy et al. 2002). Black ducks and mallards both prefer wetlands with high alkalinity and calcium for breeding (Merendino et al. 1993). As mallards expanded their breeding range into the northeastern region, the black duck population decreased (Merendino et al. 1993, Conroy et al. 2002). Additionally, when wetland quality on the breeding grounds has been improved through natural events like beaver (Castor canadensis) activity, black duck numbers stayed constant, while mallard counts improved (Conroy et al. 2002). The elevation of population-wide mallard abundance, all while black duck counts declined or remained the same, along with them using less productive habitat, suggests competition between the 2 species. As such, waterfowl managers seek ways to keep the two species apart. However, recent survey data has indicated a $32 \%$ decline from the long-term average (1993-2017) in mallards in the northeastern part of the U.S. (USFWS 2018). As such, it is important to understand what habitat variables are 
meaningful for both black ducks and mallards individually so that we may provide improved wintering habitat for both species in the northeast and aid in bolstering survival.

Throughout the wintering period, waterfowl change habitats often for a variety of reasons, not exclusive to ice coverage, food availability, shelter from poor weather, pair bonding, and disturbance (Mendall 1949, Jorde et al. 1984, Morton et al. 1989, Longcore and Gibbs 1988). Intertidal mudflats and coastal marshes are considered to be highly important to wintering black ducks (Hartman 1963). Large flocks of wintering black ducks in Maine strongly selected for mudflats with high clam densities and used small ice-free areas caused by fluctuating tides for intense, short-lived bouts of foraging when most waterbodies were frozen over (Hartman 1963). As such, in some areas like Maine and Canada, habitat shifting to acquire nutrients is minimal, limiting black ducks to tidally influenced areas and habitats with high food density (Hartman 1963, Albright et al. 1983, Morton et al. 1989). This strategy of staying put, however, is not feasible in Appalachia where waterbodies are not tidally influenced, are solely freshwater, and where palustrine systems are the predominant available habitat type, which are more vulnerable to freeze due to shallower depths, standing water, and smaller surface area (Cowardin et al. 1979, Yannuzzi Chapter 2). As such, we would expect to see a wider use of habitats from black ducks in order to meet nutritional and other needs throughout the winter. Inland studies of wintering habitat selection have shown that black ducks strongly select for scrub-shrub and emergent wetlands, two subsystems of the palustrine system (Newcomb 2014, McClanahan 2015, Osborn 2015). While use within palustrine systems has been studied, wintering habitat occupancy among aquatic systems as a whole is poorly understood in this region where waterfowl must resort to finding food and open water when preferred habitat is frozen. Meanwhile, mallards are known for exploiting all kinds of habitats, from palustrine wetlands 
where they take advantage of moist-soil and forested habitats, to agricultural fields, rivers, and increasingly urban landscapes (Figley and VanDruff 1982, Jorde et al. 1984, English et al. 2017, Osborn et al. 2017). As such, we would not expect to see mallard occupancy and abundance strongly associated with any environment in particular, as all these habitats are readily available in Central Appalachia.

Wintering dabbling ducks in Oklahoma favored natural wetlands over created impoundments (Heitmeyer and Vohs 1984), similar to breeding waterfowl in North Dakota's prairie pothole region, where $84 \%$ of breeding ducks (ranging between 70 and $88 \%$ depending on specific region and year) were found on natural ponds and lakes, with the remaining percentage split among various types of manmade wetlands (Stewart and Kantrud 1973, Ruwaldt et al. 1979). Black ducks in Virginia foraged in open tidal water as opposed to refuge impoundments, favoring natural waterbodies for nutrient acquirement (Morton et al. 1989). More broadly along the Atlantic Coast, black ducks relied greatly on saltmarsh, along with forested wetlands throughout the winter; however, urban environments were still used by some when saltmarsh was less available, relying upon human subsidies instead (Ringelman et al. 2015, English et al. 2017). As it seems to be the most favored habitat of not only dabblers, but specifically black ducks, we would expect to find black ducks exploiting natural wetlands more than created wetlands.

The objectives of our study were to determine wintering black duck and mallard use of and abundance in relation to created and natural wetlands, aquatic systems, and management schemes. We hypothesized that: 1) mallard abundance would be significantly higher in traditionally more productive wetlands (i.e., actively managed wetlands), and that 2) black duck abundance and habitat occupancy would be higher in traditionally less productive wetlands (i.e., 
passively managed and unmanaged wetlands, and riverine systems) as past research has shown them not benefitting from high-quality habitat when mallards were also present (Conroy et al. 2002). We also hypothesized that 3) both black ducks and mallards would favor natural wetlands as past research shows natural wetlands being selected for by both breeding and wintering waterfowl, and that 4) black duck occupancy and abundance would be higher in palustrine systems, while mallards would not be strongly associated with any aquatic systems. Lastly, we hypothesized that 5) wintering black duck habitat use is affected by winter weather variables. Our goal was to determine the validity of the preceding hypotheses so that we can work towards improving wintering management practices for black ducks throughout Central Appalachia.

\section{STUDY AREA}

This study was conducted in 12 counties $(2,258,654$ ha) in western Pennsylvania and 28 counties $(1,220,646$ ha) in north-central West Virginia. East of the Mississippi River, these 2 states have the highest mean elevations (NCDC 2018), with most of the study area falling within the Appalachian Plateau physiographic division (201 - $978 \mathrm{~m})$. A small portion is in the lower elevated Central Lowlands Division (173 - 305 m) found around Lake Erie in Erie County, PA (Sevon 2000, WVGES 2015). The study area is highly diverse in its elevation with low valleys and high ridges throughout the Plateau (NCDC 2018).

Having such a multifaceted topography with a westerly winter wind, mean monthly temperatures fall between -5 and $21.5^{\circ} \mathrm{C}$, making it a temperate climate (PSU 2016). The winter period is marked by harsh and unpredictable weather, with the northern half receiving heavy lake-effect snow (Kunkel et al. 2000, NCDC 2018). Freezing temperatures begin to occur between September and October, with average localized lows ranging between -6.7 and $-1.1^{\circ} \mathrm{C}$, elevation-dependent (NCDC 2018). Local annual snowfall averages range from $51-256 \mathrm{~cm}$ in 
the winter (NCDC 2018). Mean snowfall in the study area can have extreme local spikes, with the northern end of the study area around Lake Erie averaging accumulations of $256 \mathrm{~cm}$ (NCDC 2018, NWS 2018).

Surveyed wetland sites consisted of both publicly (i.e., state wildlife management areas, state, county, and city parks, and national wildlife refuges) and privately-owned wetlands. Wetlands within the study area were classified into 6 categories: Freshwater Emergent, Freshwater Forested/Scrub-Shrub Wetland, Freshwater Pond, Riverine, Lake, and Other (USFWS 2015). Overall, palustrine systems were the most abundant (83,091.67 ha), followed by riverine systems $(54,565.38 \mathrm{ha})$, and lacustrine systems $(26,322.89 \mathrm{ha})$.

\section{METHODS}

We performed diurnal (0600 - 1800 hours) waterfowl count surveys every other week for two years (i.e., November 2015 through March 2016, and November 2016 through March 2017). We completed surveys on 10 routes in the first year, with 5 in West Virginia and 5 in Pennsylvania. Survey routes were made to last 6-8 hours and consisted of designated survey points. We added additional survey points in the second year to obtain improved coverage throughout the study area, making 8 survey routes in Pennsylvania. We performed 7 replicate surveys in the first year and 8 replicate surveys in the second year. We chose survey sites using a stratified random sample based on latitude in which we tried to include all combinations of wetland systems (i.e., lacustrine, palustrine, and riverine), levels of naturalness (i.e., created, modified, and natural wetlands; Table 1), and management schemes (i.e., actively managed, passively managed, and unmanaged; Table 1) within each stratification. The average distance of wetlands from the nearest public road was $1,423.04 \mathrm{~m}(\mathrm{SE}=72.29)$, with the minimum distance being $0.54 \mathrm{~m}$ and 
the maximum distance at 5,945.8 $\mathrm{m}$. Access roads provided closer entrance to wetlands that were further from a public road so that foot travel was reduced to $\leq 2 \mathrm{~km}$.

When performing count surveys of black ducks and mallards, all precautions were taken to reduce site disturbance. When possible, surveys were performed from within a vehicle. If this was not possible, or the vehicle created a noticeable disturbance, a discrete location near the wetland edge was selected. Survey points were selected so that observers could view the entire wetland. We conducted surveys in all weather conditions, except when extreme fog prohibited surveys. On those occasions, observers would return later in the day or the next day when visibility improved. We recorded survey-level covariates recorded at each point, including Beaufort scale wind speed (Appendix Q; NABBS 2018), ambient temperature $\left({ }^{\circ} \mathrm{C}\right)$, military time, U.S. Weather Bureau sky condition codes (Appendix R; NABBS 2018), percent ice cover, percent wetland basin (i.e., waterbody surface area minus the overlapping percent vegetation area), and potential disturbances present during the survey. Disturbances present included: active hunting, predator presence, pedestrian presence, vehicular traffic, boat traffic, construction, observer-inflicted, active fishing, food handouts, and dog presence. Site-level covariates included study year, wetland system, level of naturalness, wetland management, active beaver presence, whether a wetland was public or private (i.e., land ownership), and surrounding land use within $200 \mathrm{~m}$ of a survey point. We coded active beaver presence and land ownership as either a 1 (beaver present/public land) or 0 (beaver absent/private land). We determined land ownership at the site-level based on if an area was known to be open to the public or not (i.e., a public wildlife management area vs. a private property pond).

We recorded potential disturbances as 0 (absent) or 1 (present). Additionally, we later consolidated U.S. Weather sky condition codes 4 ( $n=31,1.26 \%$ of total observations), 5 ( $n=$ 
$153,6.22 \%)$, and $8(n=156,6.34 \%)$ to one all-encompassing precipitation group due to few observations of these weather events. We evaluated local land cover types using National Land Cover Database raster data (NLCD; Homer et al. 2015) and made a local area buffer of $200 \mathrm{~m}$ around each survey point with $\operatorname{ArcGIS}^{\circledR}$. We collapsed several land use types formerly classified by NLCD, based on Anderson et al. (1976). This resulted in 8 land cover categories: open water, developed, barren land, forest, herbaceous, pasture and hay, cultivated crops, and wetlands.

Using unmarked version 3.3.3 with program $\mathrm{R}$ version 3.3.1 (Fiske and Chandler 2011, R Core Team 2017), we implemented both single-season occupancy and n-mixture models on black duck and mallard survey data. For single-season occupancy modeling, we coded black duck and mallard counts during each survey period as detected, not detected, or N/A (i.e., missed survey). Since we typically performed 7 surveys at each site in the first year and 8 in the second, we treated the first survey of the $2015-2016$ year as a missed survey (N/A) because of stacking. We created a global model for both black ducks and mallards, relating species-specific counts and occupancy to wetland system, level of naturalness, management scheme, land use, beaver presence, and land ownership, and species-specific detection to wind speed, sky condition, temperature, ice cover, basin, and disturbance presence (R Core Team 2017). We removed variables from models when Wald test $\mathrm{z}$-score values were $<1.96$, indicating variables were not contributing significantly to the model (Royle and Dorazio 2008). We then made a single reduced model for both black ducks and mallards. We then used Akaike's Information Criterion (AICc) model selection to choose a top model from both single-season occupancy models and Nmixture models (Burnham and Anderson 2002, Mazerolle 2017). We then compared AICc values across all models and identified competing models as those that had $\Delta \mathrm{AICc}$ values $<2$, as they are models that are considered to have substantial support (Burnham and Anderson 2002). 
We made predictions from competing models using R package MuMIn to implement model averaging with shrinkage to compensate for uncertainty when predictors are combined with other variables in models (Cade 2015, Barton 2018).

\section{RESULTS}

\section{Single-Season Occupancy Model}

We surveyed 141 individual points study area-wide the first year and 203 in the second. Our top single-season occupancy model included presence of disturbance as a detection covariate, and year, wetland system, management scheme, and level of wetland naturalness as occupancy covariates (Table 2). We detected black ducks at 49 of the survey sites in combined years, with 44 detections (4.8\%) in 2015-2016 and 39 detections (2.5\%) in 2016-2017. Black duck occupancy was greater in 2016-2017 ( $P=0.003$; Fig. 1A), and positively associated with palustrine systems $(P=0.003$; Fig. 1B), passively managed wetlands $(P=0.03$; Fig. $1 \mathrm{C})$, and modified wetlands $(P=0.006$; Fig. 1D). Presence of a disturbance was positively associated with black duck detection $(P=0.001)$. No competing models (models with a $\triangle \mathrm{AICc}$ value $<2$ ) were detected.

Our top single-season occupancy model for mallards included ice coverage and presence of disturbance as a detection covariate, and surrounding developed land as an occupancy covariate. We detected mallards at 182 of the survey sites in combined years, with 186 detections (20\%) in 2015-2016 and 268 detections (17\%) in 2016-2017. Ice cover of 76-100\% was negatively associated with mallard detection $(P=0.0005)$. Presence of a disturbance was positively associated with mallard detection $(P=0.001)$. Surrounding developed land use was a significant positively associated predictor of mallard occupancy $(P<0.0001$; Fig. 2). No competing models (models with a $\triangle$ AICc value $<2$ ) were detected. 


\section{N-Mixture Models}

For black ducks, we detected 2 competing models which were then model averaged with shrinkage (Table 3). Black duck abundance was negatively associated with year $(P<0.0001$; Fig. 3A) and positively associated with wetland size $(P<0.0001$; Fig. 3B $)$, palustrine systems $(P$ $=0.009$; Fig. 3C), riverine systems $(P<0.0001$; Fig. 3C), modified wetlands $(P<0.0010$; Fig. 3D), passively managed wetlands ( $P<0.0001$; Fig. 3E), unmanaged wetlands $(P=0.0003$; Fig. 3E), and presence of a beaver $(P=0.002 ;$ Fig. 3F). Black duck abundance was also positively associated with surrounding barren land $(P=0.003$; Fig. 4A), forested land $(P<0.0001$; Fig. 4B), herbaceous land $(P<0.0001 ; 4 C)$, cultivated cropland ( $P<0.0001$; Fig. 4D), and wetland $(P<0.0001 ; 4 \mathrm{E})$. Black duck abundance was negatively associated with surrounding hay pasture land $(P=0.02 ;$ Fig. $4 \mathrm{~F})$. Detection of black ducks was positively associated with the presence of a disturbance $(P<0.0001)$, wetland basin water coverage of $26-50 \%(P=0.006), 51-75 \%(P<$ $0.0001)$, and $76-100 \%(P=0.047)$, ice cover of $0-25 \%(P<0.0001)$ and $51-75 \%(P<0.0001)$, wind speed codes of $1(P=0.003), 2(P=0.0001)$, and $3(P<0.0001)$, and sky codes of $1(P=$ $0.0001), 2(P<0.0001)$, and $7(P=0.002)$. For mallards, we detected no competing models. Mallard abundance was positively associated with wetland size $(P<0.0001$; Fig. 5A), palustrine systems $(P<0.0001$; Fig. 5B), surrounding developed land $(P<0.0001$; Fig. 5C), open water $(P$ $<0.0001$; Fig. 5D), barren land ( $P=0.004$; Fig. 5E), forest land ( $P<0.0001$; Fig. 5F), hay pasture $(P<0.0001$; Fig. 6A), cultivated cropland $(P<0.0001$; Fig. 6B), and wetland $(P<$ 0.0001 Fig. 6C). Mallard abundance was negatively associated with riverine systems $(P<0.0001$ Fig. 5B), modified wetlands ( $P<0.0001$; Fig. 6D), and passively $(P=0.04$; Fig. 6E) and unmanaged wetlands $(P=0.0005 ;$ Fig. $6 \mathrm{E})$. Mallard abundance was also higher in privatelyowned than publicly-owned wetlands $(P<0.0001 ;$ Fig. 6 F). Mallard detection was positively 
associated with the presence of a disturbance $(P<0.0001)$, wetland basin water coverage of 0 25\% $(P<0.0001), 26-50 \%(P<0.0001), 51-75 \%(P<0.0001)$, and $76-100 \%(P<0.0001), 51-$ $75 \%$ ice coverage $(P=0.001)$, wind speed code of $3(P<0.0001)$, wind speed code of 4 ( $P<$ $0.0001)$, wind speed code of $5(P<0.0001)$, sky code of $2(P<0.0001)$, sky code of 5 ( $P<$ $0.0001)$, and sky code of $7(P=0.01)$. Mallard detection was negatively associated with 76$100 \%$ ice coverage $(P<0.0001)$, temperature $(P=0.006)$, and a wind speed code of $1(P<$ $0.0001)$.

\section{DISCUSSION}

We studied black duck and mallard habitat use in western Pennsylvania and north-central West Virginia to determine the relation to wetland creation and management practices. Wetland system, management scheme, and level of naturalness were all significant black duck occupancy covariates. Black duck occupancy and abundance was positively associated with modified wetlands. From benthic core sampling throughout the study area, we found that modified wetlands had significantly higher available biomass and energy than either natural or created wetlands, which largely came from modified wetlands having the highest macroinvertebrate biomass, as well (Yannuzzi Chapter 1). Modified wetlands, when restructured to perform similarly to natural wetlands, can provide habitats that are important to waterbirds by providing favorable foods and water depths conducive to foraging (Fredrickson and Reid 1988). In the winter, black duck diet is comprised of $>90 \%$ invertebrates (Costanzo and Malecki 1989). Invertebrates contain a high amount of protein, which is vital for waterfowl reproduction and survival (Reinecke et al. 1982, Costanzo and Malecki 1989, Anderson and Smith 1998, Cramer et al. 2012). As such, black ducks were likely exploiting modified wetlands for their abundant macroinvertebrate availability to meet their wintering dietary needs. 
Black duck occupancy and abundance was highest in passively managed wetlands when compared to any other management strategies. Actively managed wetlands typically contain higher biomasses of foraging items (i.e., seeds, tubers, and macroinvertebrates) than passively managed wetlands due to annual water level drawdown allowing for seed germination and invertebrate population growth (Anderson and Smith 2000, Brasher et al. 2006, Kross et al. 2007). This was further shown in Central Appalachia, in which benthic coring revealed passively managed wetlands to have the lowest biomass and energy availability in comparison to actively managed and unmanaged wetlands (Yannuzzi Chapter 1). Black duck occupancy and abundance and mallard abundance both had positive associations with palustrine systems, too, which also contained a lower biomass and energy availability relative to lacustrine systems (Yannuzzi Chapter 1). Wintering waterfowl in Oklahoma have also been shown to exploit palustrine systems more than riverine systems and reservoirs (Heitmeyer and Vohs 1984). Further, time activity budgets of black ducks wintering in Central Appalachia revealed that black ducks spend a significant amount of time foraging, loafing, sleeping, and in self-maintenance in these habitats (Yannuzzi Chapter 2). As such, we believe passively managed wetlands and palustrine systems are providing habitat conducive to black duck rest and nutrient acquisition, yet at an energetic cost to themselves (Stotts and Davis 1960, Brodsky and Weatherhead 1984). Additionally, black duck abundance was highest in riverine systems. These systems also contained the highest energy across wetland systems (Yannuzzi Chapter 1) and likely were also more thermally favorable than other environments in the winter, as Jorde et al. (1984) found these habitats to provide thermal refuge for mallards during cold snaps.

Mallards showed increased winter occupancy and abundance at sites with increasing expanses of surrounding developed land. They also had higher abundances in created wetlands. 
Mallards have expanded their range from western and central North America into more northerly and eastern sections of the country due to hunting-related releases of captive-bred birds and their generalist nature (Ankney et al. 1987, English et al. 2017). They are known to use urban environments for food, favorable microclimate, and increasingly, breeding habitat (Figley and VanDruff 1982, Donaldson et al. 2007, Welsh et al. 2016, English et al. 2017). As such, mallards are taking advantage of, in both quantity of habitat and number of birds, environments in urban landscapes while wintering in Central Appalachia. Not only are mallards taking advantage of developed habitats though, but mallard abundance was also found to be positively associated with many landscapes, including: pasture and cropland, forest, barren land, and both additional surrounding open water and wetlands. Similarly, black duck abundances increased with increasing surrounding crop land, forest, barren land, and herbaceous land. Unlike mallards, black duck abundances were negatively associated with surrounding pasture land. Both black ducks and mallards have shown increased adaptation towards and use of a number of environments in order to take advantage of food resources, thermal environment, for protection, and for roosting, and as such, a variety of habitats appear to be important to wintering black ducks and mallards in Central Appalachia, as well (Figley and VanDruff 1982, Baldassarre 2014, English et al. 2017). Additionally, black duck abundances were positively associated with habitats that contained an active beaver presence, similar to past research performed on breeding black ducks that found they tended to breed in habitats created or modified by beavers, preferred habitats where an active beaver was present, and led their broods to beaver ponds, too (Renouf 1972, Diefenbach and Owen 1989, Baldassarre 2014). As such, presence of a beaver appears to not only be integral to black ducks during the breeding period, but also during the wintering period. 
Furthermore, mallard abundance was highest in actively managed wetlands and privatelyowned wetlands. While actively managed wetlands in the study area did not hold the highest biomass per hectare, they did contain significantly higher biomass than passively managed wetlands, and as such, mallards appear to be congregating in higher quality habitats (Yannuzzi Chapter 1). Additionally, mallard abundance was highest in privately-owned wetlands. Publiclyowned lands in the study area are considered to be those that are both publicly owned and open to hunting. Past research has shown that mallards respond by flying farther away when exposed to shooting disturbance more so than walk-in or no disturbance, and that waterfowl overall typically use hunted areas less (Madsen 1998, Dooley et al. 2010). Additionally, presence of mallards that have been exposed to shooting was much lower during diurnal hours than mallards that had not been exposed to shooting (Dooley et al. 2010). As such, we believe it is likely that mallards are taking advantage of the less frequently hunted private lands in the region during diurnal hours to seek refuge.

We identified significantly lower black duck occupancy and abundance in the second year of the study than in the first. The average temperature during the survey period in 2015 2016 was $4.15{ }^{\circ} \mathrm{C}$ and $4.72^{\circ} \mathrm{C}$ in $2016-2017$. Twenty days in the first year and 13 days in the second year had daily averages of $-5^{\circ} \mathrm{C}$ or below. We speculate that the discrepancy in occupancy between years was due to somewhat milder winter weather patterns on staging grounds in the second year of the study. Black duck movements are influenced by weather patterns (Brodsky and Weatherhead 1984, Prince et al. 1992, Baldassarre 2014). Black ducks have been wintering farther north at an increased rate (1.0-16.0\% per year) over the past 45 years, with regional populations shown to be stable in the north and declines in the southern and central parts of their range (Link et al. 2006, Robertson et al. 2017). Furthermore, black duck 
abundances increased in Ontario midwinter counts as they decreased in midwinter waterfowl surveys (MWS) (Brook et al. 2009). Following this trend, increased delayed migration of black ducks and other waterfowl has been documented, anticipating greater numbers of both black ducks and mallards to overwinter in the Great Lakes region (Notaro et al. 2016). As such, we suspect that many birds stayed farther north of the study area around the Great Lakes in the second year when regional weather conditions overall were milder.

Presence of a disturbance was positively associated with the detection of black ducks and mallards, likely as a result of disturbance conditioning. Black ducks are often regarded as a skittish species, commonly evacuating wetlands when bothered. As such, it is likely that detections rose with increasing disturbance because most of the black ducks using those wetlands were acclimated to commotion, and as a result, did not spook from corresponding disturbances as quickly as those that frequented wetlands farther from the road. While Morton et al. (1989) showed that human-disturbance increased energy expenditure of black ducks, Conomy et al. (1998) found that while black ducks are initially disturbed by human-induced noise such as jet engines, they quickly become habituated to external disturbance when the disturbance is repeated often. Our belief is that black ducks in our study area became habituated to disturbances in areas of high commotion and therefore were easier to detect during surveys. Additionally, mallards are considered generalists that exploit most available habitats, and recent research has indicated that both black ducks and mallards are likely becoming less cautious in order to take advantage of habitats, like urban environments, that aid in winter survival (English et al. 2017). As such, it makes sense that we would detect mallards and black ducks more often in areas with sources of disturbance as they are likely frequenting these areas in the winter for purposes of survival. 


\section{MANAGEMENT IMPLICATIONS}

Due to strong evidence for black duck selection of riverine systems, passively managed wetlands, and habitats with an active beaver presence, incorporating this practice at more currently unmanaged riverine wetland sites and permitting beaver activity may allow for increased important habitat for wintering black ducks. As mallards showed negative relationships with both riverine systems and passively managed wetlands, passively managing riverine systems in areas may allow for some relief in habitat overlap between the two species. Additionally, managing for these habitats on public land may allow for further separation of habitat use between the species, as mallards used public lands significantly less than private lands. We suggest future research incorporates the addition of transmitters to analyze overall black duck and mallard habitat use at a finer scale, as our road-based surveys likely detected black ducks and mallards that were already acclimated to human-induced disturbances, thus potentially neglecting a portion of wintering black ducks and mallards in the study area.

\section{ACKNOWLEDGMENTS}

We are appreciative of the financial support provided for this study by the U.S. Fish and Wildlife Service through the Black Duck Joint Venture, the Pennsylvania Game Commission, the West Virginia Division of Natural Resources, and West Virginia University. J. T. Anderson was supported by the National Science Foundation under Cooperative Agreement No. OIA-1458952, the USDA National Institute of Food and Agriculture, McIntire Stennis project WVA00117, and the West Virginia Agricultural and Forestry Experiment Station during manuscript preparation. We thank J. S. Carr, C. McDougal, M. A. Petschauer, J. Stempka, B. Ellis, K. Jacobs, D. Dowler, 
T. Pratt, T. Shreve, J. McCrady, T. Hardman, J. Allison, J. Sammons, and M. L. Spindler for their assistance in fieldwork. This is scientific article number $\operatorname{xxxx}$ of the West Virginia Agricultural and Forestry Experiment Station, Morgantown.

\section{LITERATURE CITED}

Albright, J. J., R. B. Owen, Jr., P. O. Corr. 1983. The effects of winter weather on the behavior and energy reserves of black ducks in Maine. Transactions of the Northeast Section of the Wildlife Society 40:118-128.

Anderson, J. R., E. E. Hardy, J. T. Roach, and R. E. Witmer. 1976. A land use and land cover classification system for use with remote sensor data. Geological Survey Professional Paper 964. U.S. Department of the Interior, U.S. Geological Survey.

Anderson, J. T. and L. M. Smith. 1998. Protein and energy production in playas: implications for migratory bird management. Wetlands 18:437-446.

Anderson, J. T., and L. M. Smith. 2000. Invertebrate response to moist-soil management of playa wetlands. Ecological Applications 10:550-558.

Ankney, C. D., D. G. Dennis, and R. C. Bailey. 1987. Increasing mallards, decreasing American black ducks: coincidence or cause and effect? Journal of Wildlife Management 51:523529.

Baldassarre, G. 2014. Ducks, geese, and swans of North America. Revised and updated edition. Johns Hopkins university Press, Baltimore, Maryland, USA.

Barton, K. 2018. MuMIn: Multi-Model Inference. R package version 1.42.1. <https://CRAN.Rproject.org/package $=$ MuMIn $>$. 
Brasher, M. G., J. D. Steckel, and R. J. Gates. 2006. Energetic carrying capacity of actively and passively managed wetlands for migrating ducks in Ohio. Journal of Wildlife Management 71:2532-2541.

Brodsky, L. M., and P. J. Weatherhead. 1984. Behavioral and ecological factors contributing to American black duck-mallard hybridization. Journal of Wildlife Management 48:846852.

Brook, R. W., R. K. Ross, K. F. Abraham, D. L. Fronczak, and J. C. Davies. 2009. Evidence for black duck winter distribution change. Journal of Wildlife Management 73:98-103.

Burnham, K. P., and D. R. Anderson. 2002. Model selection and multi-model inference. Second edition. Springer, Berlin, Germany.

Cade, B. S. 2015. Model averaging and muddled multimodel inferences. Ecology 96:2370-2382.

Collins, J. M. 1974. The relative abundance of ducks breeding in southern Ontario in 1951 and 1971. Pages 32-44 in H. Boyd, ed. Canadian Wildlife Service waterfowl studies in eastern Canada, 1969-73. Canadian Wildlife Services Report Ser. 29.

Conomy, J. T., J. A. Dubovsky, J. A. Collazo, and W. J. Fleming. 1998. Do black ducks and wood ducks habituate to aircraft disturbance? Journal of Wildlife Management 62:11351142.

Conroy, M. J., G. R. Costanzo, and D. B. Stotts. 1989. Winter survival of female American black ducks on the Atlantic coast. Journal of Wildlife Management 53:99-109.

Conroy, M. J., M. W. Miller, and J. E. Hines. 2002. Identification and synthetic modeling of factors affecting American black duck populations. Wildlife Monographs 150:1-64.

Costanzo, G. R. and R. A. Malecki. 1989. Foods of black ducks along coastal New Jersey. Dissertation, Cornell University, Ithaca, NY, USA. 
Cowardin, L. M., V. Carter, F. C. Golet, and E. T. LaRoe. 1979. Classification of wetlands and deepwater habitats of the United States. U.S. Department of the Interior, Fish and Wildlife Service, Washington, D.C. Jamestown, ND: Northern Prairie Wildlife Research Center Online. <http://www.npwrc.usgs.gov/resource/wetlands/classwet/index.htm>.

Cramer, D. M., P. M. Castelli, T. Yerkes, and C. K. Williams. 2012. Food resources availability for American black ducks wintering in southern New Jersey. Journal of Wildlife Management 76:214-219.

Dahl, T. E. 2011. Status and trends of wetlands in the conterminous United States 2004 to 2009. U.S. Department of the Interior; Fish and Wildlife Service, Washington, D.C.

Diefenbach, D. R. and R. B. Owen, Jr. 1989. A model of habitat use by breeding American black ducks. Journal of Wildlife Management 53:383-389.

Donaldson, M. R., K. M. Henein, and M. W. Runtz. 2007. Assessing the effect of developed habitat on waterbird behaviour in an urban riparian system in Ottawa, Canada. Urban Ecosystems 10:139-151.

Dooley, J. L., T. A. Sanders, and P. F. Doherty, Jr. 2010. Mallard response to experimental walkin and shooting disturbance. Journal of Wildlife Management 74:1815-1824.

Drilling, N., R. D. Titman, and F. McKinney. 2002. Mallard (Anas platyrhynchos). Cornell Lab of Ornithology: Birds of North America. <https://birdsna.org/SpeciesAccount/bna/species/mallar>.

English, M. D., G. J. Robertson, L. E. Peck, and M. L. Mallory. 2017. Agricultural food resources and the foraging ecologies of American black ducks (Anas rubripes) and mallards (Anas platyrhynchos) at the northern limits of their winter ranges. Urban Ecosystems 30:1311-1318. 
Figley, W. K. and L. W. VanDruff. 1982. The ecology of urban mallards. Wildlife Monographs 81:3-39.

Fiske, I. and R. Chandler. 2011. Unmarked: An R package for fitting hierarchical models of wildlife occurrence and abundance. Journal of Statistical Software 43:1-23. <http://www.jstatsoft.org/v43/i10/>.

Fredrickson, L. H. and F. A. Reid. 1988. 13.2.1 Waterfowl use of wetland complexes. Waterfowl Management Handbook 1:1-6.

Hartman, F. E. 1963. Estuarine wintering habitat for black ducks. Journal of Wildlife Management 27:339-347.

Heitmeyer, M. E. and P. A. Vohs, Jr. 1984. Distribution and habitat use of waterfowl wintering in Oklahoma. Journal of Wildlife Management 48:51-62.

Heusmann, H. W. 1974. Mallard-black duck relationship in the northeast. Wildlife Society Bulletin 2:171-177.

Homer, C. G., J. A. Dewitz, L. Yang, S. Jin, P. Danielson, G. Xian, J. Coulston, N. D. Herold, J. D. Wickham, and K. Megown. 2015. Completion of the 2011 National Land Cover Database for the conterminous United States - Representing a decade of land cover change information. Photogrammetric Engineering and Remote Sensing 81:345-354.

Jorde, D. G., G. L. Krapu, R. D. Crawford, and M. A. Hay. 1984. Effects of weather on habitat selection and behavior of mallards wintering in Nebraska. Condor 86:258-265.

Kross, J., R. M. Kaminski, K. J. Reinecke, E. J. Penny, and A. T. Pearse. 2007. Moist-soil seed abundance in managed wetlands in the Mississippi Alluvial Valley. Journal of Wildlife Management 72:707-714. 
Kunkel, K. E., N. E. Westcott, and D. A. R. Kristovich. 2000. Climate change and lake-effect snow in Preparing for a Changing Climate: The Potential Consequences of Climate Variability and Change, Great Lakes Overview. Illinois State Water Survey, Champaign, Illinois. <http://geo.msu.edu/extra/glra/PDF_files/Regional\%20Summary/03F_lake_effect.pdf>.

Link, W. A., J. R. Sauer, D. K. Niven. 2006. A hierarchical model for regional analysis of population change using Christmas Bird Count data, with application to the American black duck. The Condor 108:13-24.

Longcore, J. R. and J. P. Gibbs. 1988. Distribution and numbers of American black ducks along the Maine coast during the severe winter of 1980 -1981. Pages 377 in M. W. Weller, ed. Waterfowl in winter symposium. Univ. Minnesota Press, Minneapolis.

Longcore, J. R., D. G. McAuley, G. R. Hepp, J. M. Rhymer. 2000. American black duck (Anas rubripes). Cornell Lab of Ornithology: Birds of North America. <https://birdsna.org/Species-Account/bna/species/ambduc/>.

Madsen, J. 1998. Experimental refuges for migratory waterfowl in Danish wetlands. II. Tests of hunting disturbance effects. Journal of Applied Ecology 35:398-417.

Mazerolle, M. J. 2017. AICcmodavg: Model selection and multimodel inference based on (Q)AIC(c). R package version 2.1-1. <https://cran.r-project.org/package=AICcmodavg>.

McClanahan, M. D. 2015. Habitat use and response to wetland management practices of nonbreeding dabbling ducks in western Tennessee. Thesis, University of Tennessee, Knoxville, USA.

Mendall, H. L. 1949. Food habits in relation to black duck management in Maine. Journal of Wildlife Management 13:64-101. 
Merendino, M. T., C. D. Ankney, and D. G. Dennis. 1993. Increasing mallards, decreasing American black ducks: more evidence for cause and effect. Journal of Wildlife Management 57:199-208.

Morton, J. M., A. C. Fowler, and R. L. Kirkpatrick. 1989. Time and energy budgets of American black ducks in winter. Journal of Wildlife Management 53:401-410.

National Audubon Society. 2010. The Christmas Bird Count historical results. <http://www.christmasbirdcount.org>.

National Climatic Data Center [NCDC]. Climate of West Virginia. National Oceanic and Atmospheric Administration. Asheville, NC.

<https://www.ncdc.noaa.gov/climatenormals/clim60/states/Clim_WV_01.pdf>.Accessed 1 May 2018.

National Weather Service [NWS]. 2018. Snowfall information. National Oceanic and Atmospheric Administration. <https://www.weather.gov/cle/snowfall_info>. Accessed 1 May 2018.

Newcomb, K. C. 2014. Survival and habitat selection of American black ducks in Tennessee. Thesis, Mississippi State University, Starkville, USA.

North American Breeding Bird Survey [NABBS]. 2018. Weather Codes. U.S. Department of the Interior, U.S. Geological Survey, Patuxent Wildlife Research Center, Laurel, MD, USA 20708. <https://www.pwrc.usgs.gov/BBS/participate/training/appendixA.html>.

Notaro, M., M. Schummer, Y. Zhong, S. Vavrus, L. Van Den Elsen, J. Coluccy, and C. Hoving. 2016. Projected influences of changes in weather severity on autumn-winter distributions 
of dabbling ducks in the Mississippi and Atlantic Flyways during the twenty-first century. PLoS ONE 11:1-21.

Osborn, J. M. 2015. American black duck wintering dynamics and dabbling duck response to herbicide application in Western Tennessee wetlands. Thesis, University of Tennessee, Knoxville, USA.

Osborn, J. M., H. M. Hagy, M. D. Mcclanahan, J. B. Davis, and M. J. Gray. 2017. Habitat selection and activities of dabbling ducks during non-breeding periods. The Journal of Wildlife Management 81:1482-1493.

Pennsylvania State University [PSU]. 2016. The Pennsylvania state climatologist: regional data. Pennsylvania State Climate Office, University Park, PA. $<$ http://climate.met.psu.edu/data/>.

Prince, H. H., P. I. Padding, and R. W. Knapton. 1992. Waterfowl use of the Laurentian Great Lakes. Journal of Great Lakes Resources 18:673-699.

R Core Team. 2017. R: A language and environment for statistical computing. R Foundation for Statistical Computing, Vienna, Austria. <https://www.R-project.org/.

Reinecke, K. J., T. L. Stone, R. B. Owen, Jr. 1982. Seasonal carcass composition and energy balance of female black ducks in Maine. Condor 84:420-426.

Renouf, R. N. 1972. Waterfowl utilization of beaver ponds in New Brunswick. Journal of Wildlife Management 36:740-744.

Ringelman, K. M., C. K. Williams, P. K. Devers, J. M. Coluccy, P. M. Castelli, K. A. Anderson, J. L. Bowman, G. R. Costanzo, D. M. Cramer, M. T. DiBona, M. W. Eichholz, M. Huang, B. Lewis, Jr., D. M. Plattner, T. Yerkes. 2015. A meta-analysis of American 
black duck winter habitat use along the Atlantic coast. Journal of Wildlife Management 79:1298-1307.

Robertson, G. J., M. Tomlik, G. R. Milton, G. J. Parsons, and M. L. Mallory. 2017. Increases in the number of American black ducks wintering in Nova Scotia, 1970-2015. Journal of Fish and Wildlife Management 8:669-675.

Royle, J. A. and R. M. Dorazio. 2008. Hierarchical modeling and inference in ecology: the analysis of data from populations, metapopulations and communities. Elsevier Academic Press, Oxford, United Kingdom.

Ruwaldt, J. J., Jr., L. D. Flake, and J. M. Gates. 1979. Waterfowl pair use of natural and manmade wetlands in South Dakota. The Journal of Wildlife Management 43:375-383.

Sevon, W. D. 2000. Physiographic provinces of Pennsylvania. $4^{\text {th }}$ ed. Pennsylvania Department of Conservation and Natural Resources, Bureau of Topographic and Geologic Survey.

Stewart, R. E., and H. A. Kantrud. 1973. Ecological distribution of breeding waterfowl populations in North Dakota. The Journal of Wildlife Management 37:39-50.

Stotts, V. D. and D. E. Davis. 1960. The black duck in the Chesapeake Bay of Maryland: breeding behavior and biology. Chesapeake Science 1:127-154.

U.S. Fish and Wildlife Service [USFWS]. 2014. Waterfowl population status, 2014. U.S. Department of the Interior, Washington, DC, USA.

U.S. Fish and Wildlife Service [USFWS]. 2015. National Wetlands Inventory website. U.S. Department of the Interior, U.S. Fish and Wildlife Service, Washington, D.C. $<$ http://www.fws.gov/wetlands/>. 
U.S. Environmental Protection Agency [USEPA]. 2016. Wetlands protection and restoration website: Wetlands restoration definitions and distinctions. <https://www.epa.gov/wetlands/>.

Welsh, P. O., C. A. Paszkowski, and K. B. Tierney. 2017. Mallards (Anas platyrhynchos) and wastewater ponds, part i: mallard ducks overwintering at a northern wastewater treatment pond. Ecotoxicology and Environmental Safety 143:330-335.

West Virginia Geological \& Economic Survey [WVGES]. 2015. Physiographic Provinces of West Virginia. West Virginia Geological \& Economic Survey. <http://www.wvgs.wvnet.edu/www/geology/geolphyp.htm>. Accessed 1 Oct 2016.

Associate Editor: 
Figure 1. Occupancy probability of black ducks across years (A), wetland systems (B), and management schemes (C), and level of naturalness (D) from wintering waterfowl surveys in West Virginia and Pennsylvania, USA, November to March 2015-2016 and 2016-2017. Within the plots, the dots represent mean occupancy and the lines are $95 \%$ confidence intervals.
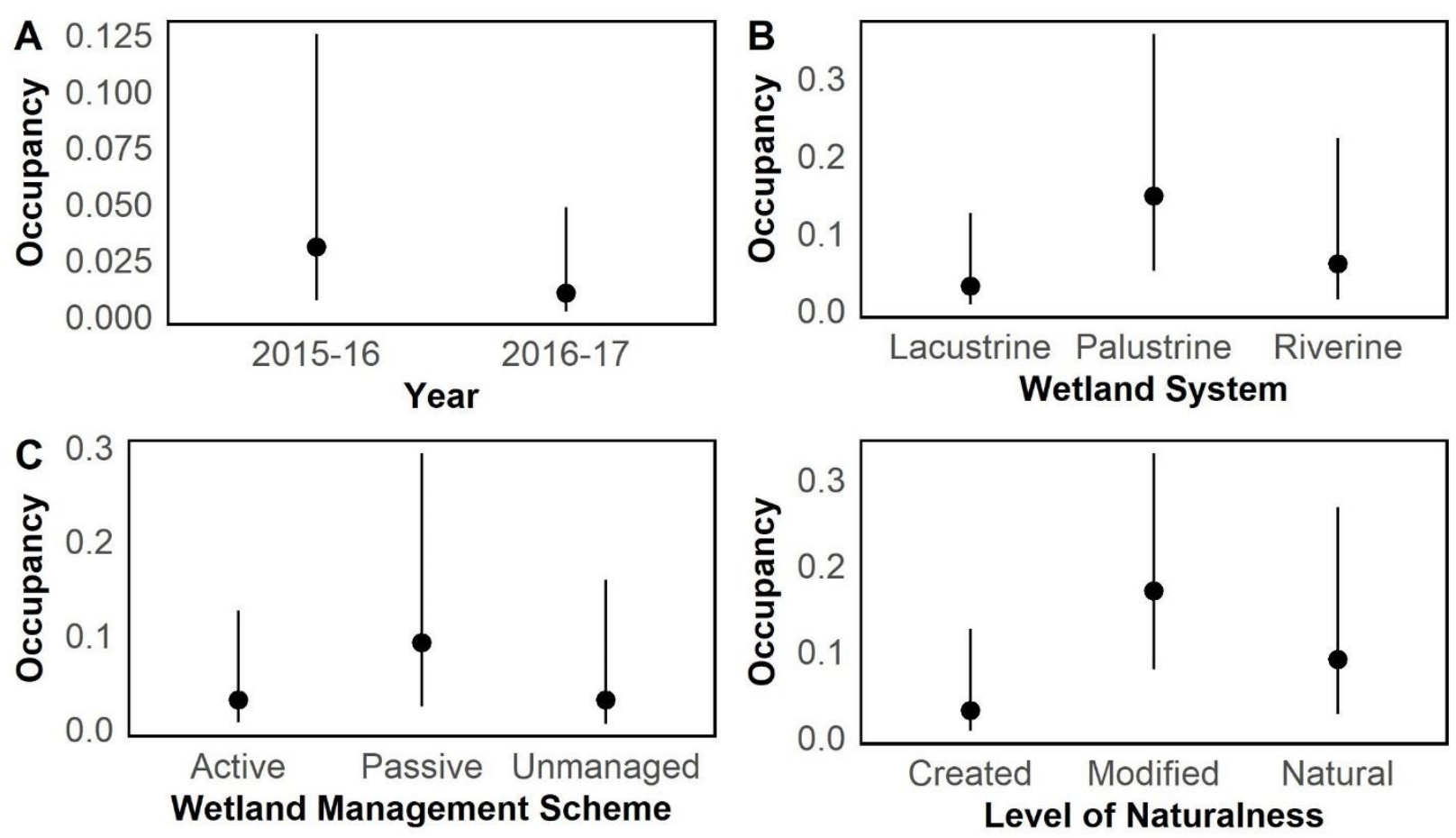
Figure 2. Occupancy probability of mallards in association with surrounding developed land use from wintering waterfowl surveys in West Virginia and Pennsylvania, USA, November to March 2015-2016 and 2016-2017.

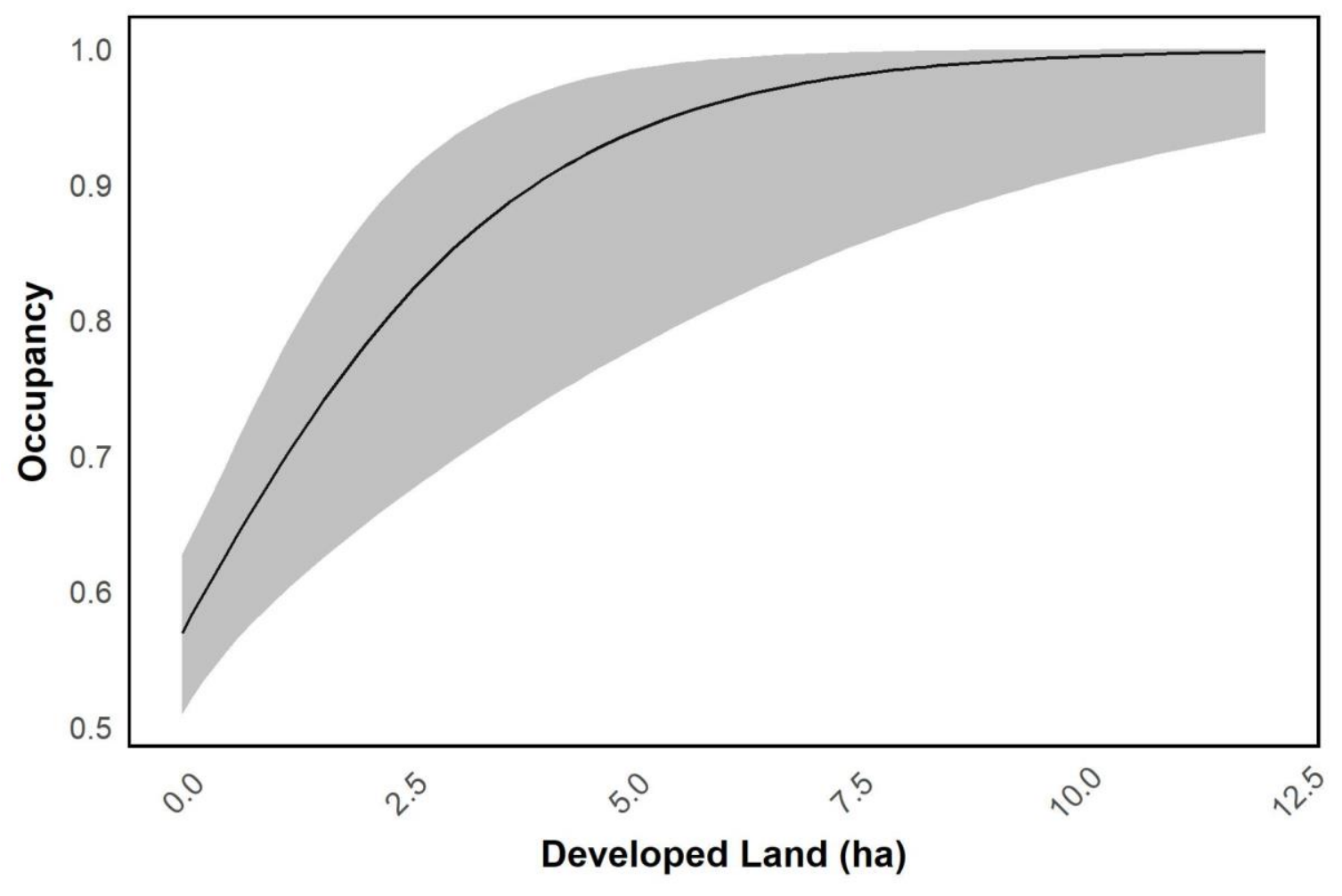


Figure 3. Abundance predictions, estimated number of individuals, from wintering waterfowl counts of black ducks in relation to year (A), wetland size (B), wetland system (C), level of naturalness (D), management scheme (E), and beaver presence (F) from wintering waterfowl surveys in West Virginia and Pennsylvania, USA, November to March 2015-2016 and 20162017. The dots represent mean abundance and the bars are $95 \%$ confidence intervals.
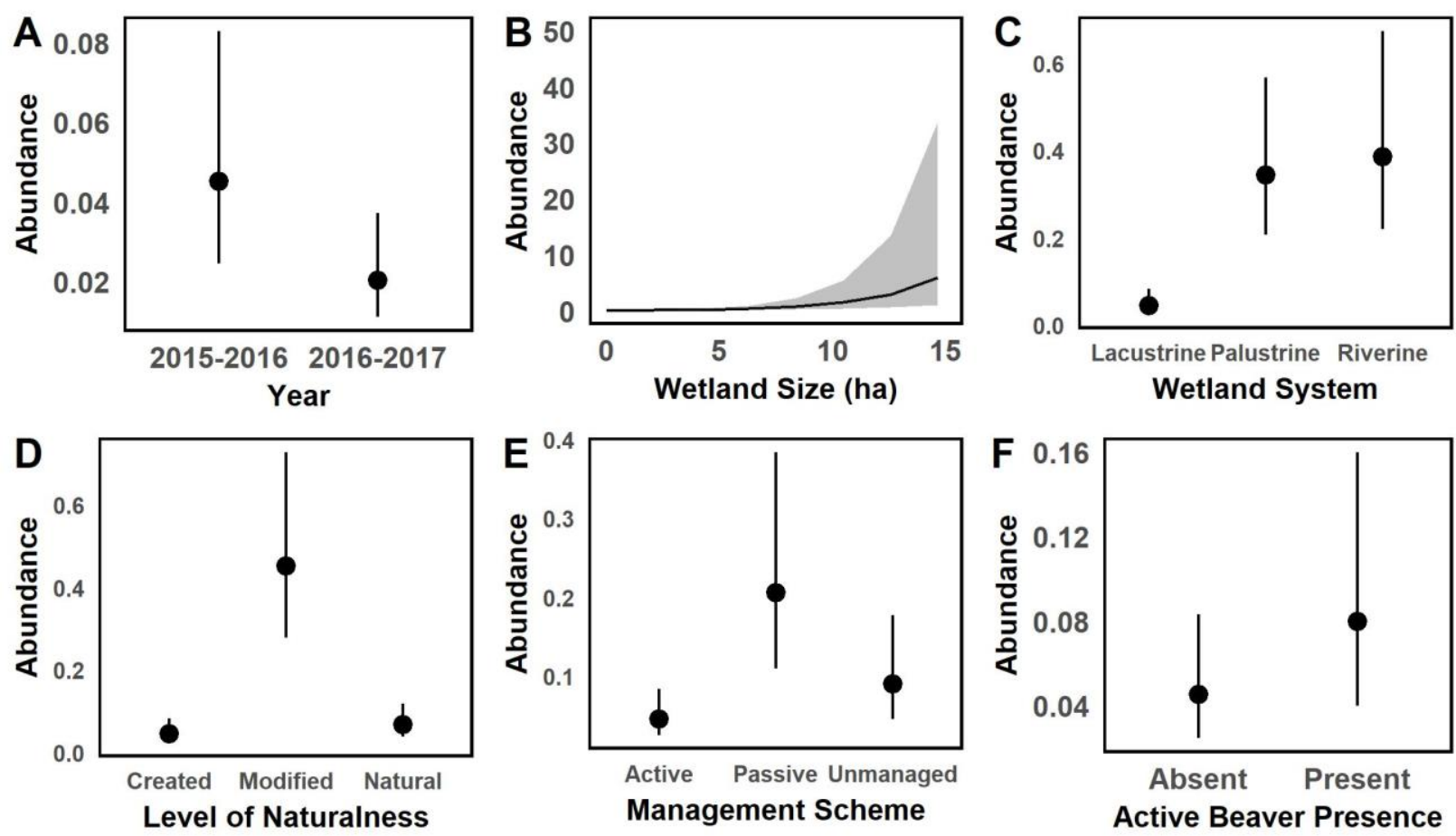
Figure 4. Abundance predictions, estimated number of individuals, from wintering waterfowl counts of black ducks in relation to barren land (A), forest land (B), herbaceous land (C), hay pasture land (D), cultivated cropland (E), and wetland (F) within $200 \mathrm{~m}$ of a survey point from wintering waterfowl surveys in West Virginia and Pennsylvania, USA, November to March 2015-2016 and 2016-2017.
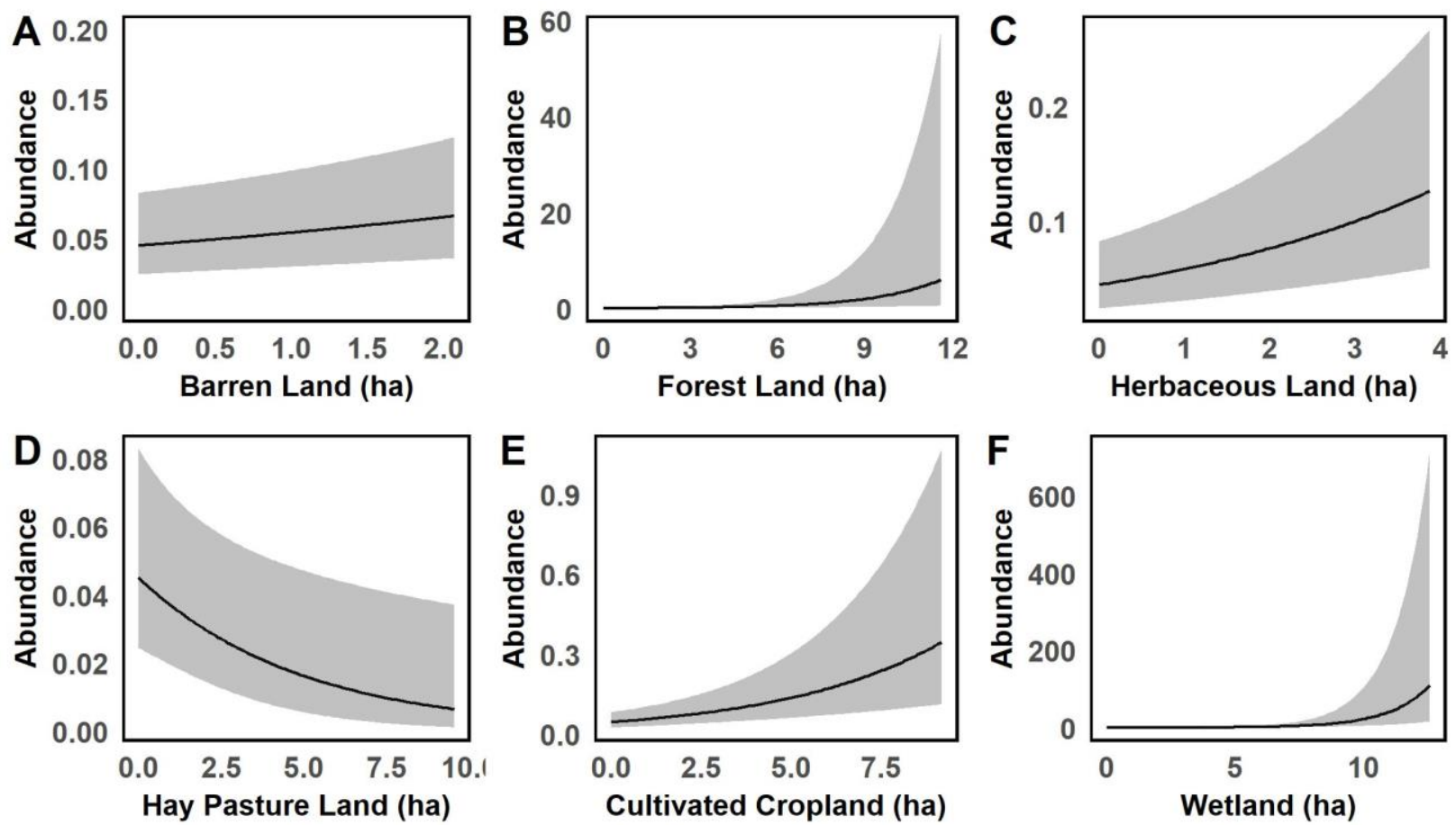
Figure 5. Abundance predictions, estimated number of individuals, from wintering waterfowl counts of mallards in relation to wetland size (A), wetland system (B), and developed land (C), open water (D), barren land (E), and forest land (F) within $200 \mathrm{~m}$ of a survey point from wintering waterfowl surveys in West Virginia and Pennsylvania, USA, November to March 2015-2016 and 2016-2017.
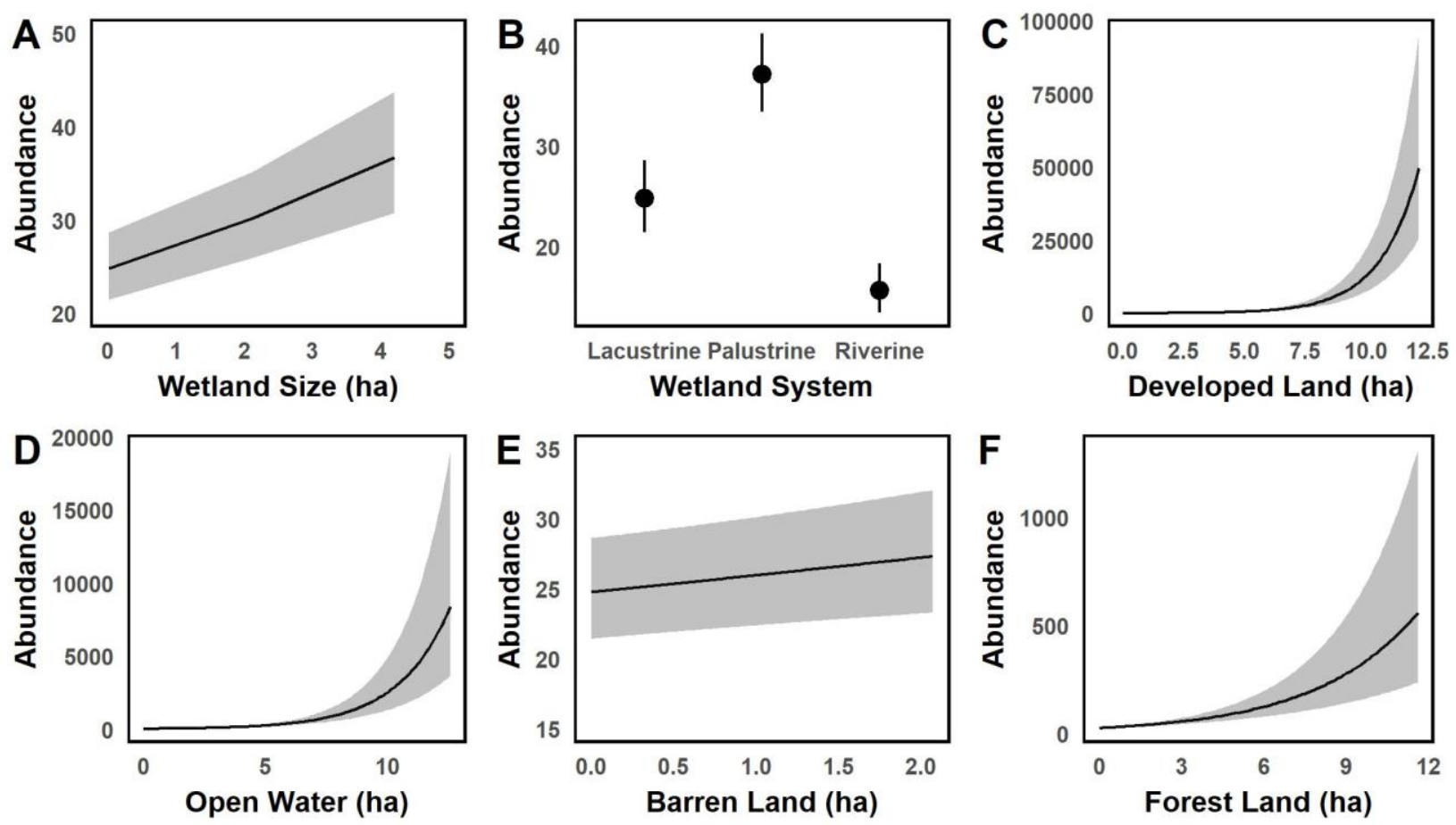
Figure 6. Abundance predictions, estimated number of individuals, from wintering waterfowl counts of mallards in relation to hay pasture land (A), cultivated cropland (B), and wetland (C) within $200 \mathrm{~m}$, level of naturalness (D), management scheme (E), and land ownership (F) of a survey point from wintering waterfowl surveys in West Virginia and Pennsylvania, USA, November to March 2015-2016 and 2016-2017.
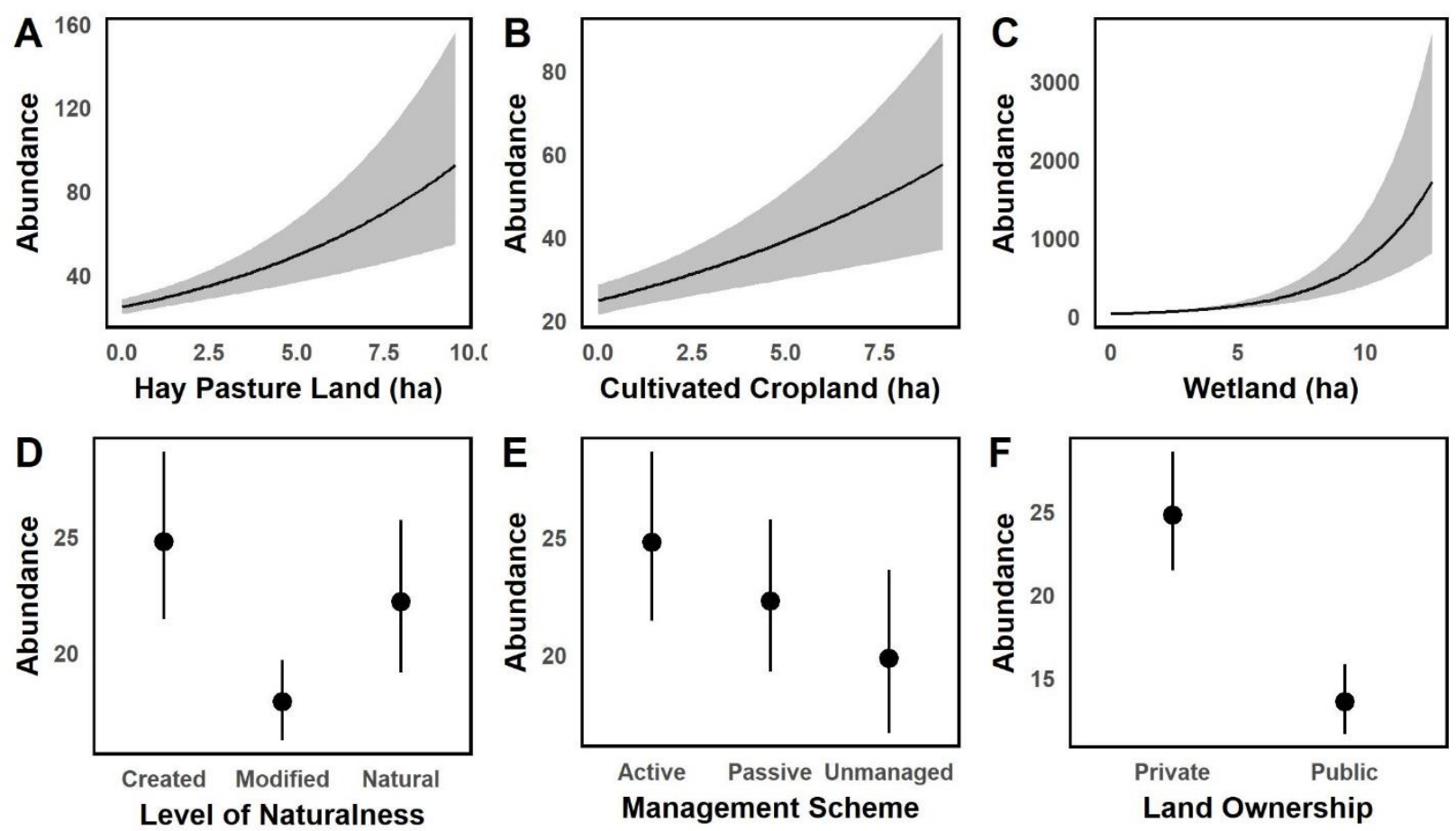
Table 1. Criteria for levels of wetland naturalness and wetland management schemes during wintering waterfowl and black duck surveys between November and March 2015 - 2016 and 2016 - 2017 in western Pennsylvania and north-central West Virginia, USA (USEPA 2016).

Level of wetland naturalness

Created

Modified

Natural

Wetland management scheme

Actively managed

Passively managed

Unmanaged
A developed wetland that did not previously exist on an upland or deep water site; excavated.

A wetland site manipulated for one or more specific functions that changes the wetland's role.

A self-regulating wetland that is integrated ecologically with its surrounding landscape.

A wetland that has some type of water control device to manipulate water levels within the wetland basin.

A wetland that is managed solely around the wetland basin, through cutting, mowing, burning, and planting.

A wetland that has no human-induced management. 
Table 2. List of single-season occupancy models used to determine the top model for black duck (ABDU) and mallard (MALL) occupancy in November and March 2015-2016 and 2016-2017 in western Pennsylvania and north-central West Virginia, USA. Models include land ownership (LO), open water within $200 \mathrm{~m}$ (OW), developed land within $200 \mathrm{~m}$ (DE), barren land within $200 \mathrm{~m}$ (BL), forested land within $200 \mathrm{~m}$ (FO), herbaceous land within $200 \mathrm{~m}$ (HE), pasture/hay within $200 \mathrm{~m}(\mathrm{PH})$, cultivated crop land within $200 \mathrm{~m}$ (CC), and wetland within $200 \mathrm{~m}$ (WE).

\begin{tabular}{|c|c|c|c|c|c|}
\hline Species & Detection & Occupancy & $\mathrm{AICc}$ & $\triangle \mathrm{AICc}$ & $\begin{array}{l}\text { Cum. } \\
\text { Wt }\end{array}$ \\
\hline \multirow[t]{3}{*}{$\mathrm{ABDU}$} & Disturbance & $\begin{array}{c}\text { Year + System + Natural + } \\
\text { Management }\end{array}$ & 619.74 & 0.00 & 1.00 \\
\hline & Constant & Constant & 639.89 & 20.15 & 1.00 \\
\hline & $\begin{array}{c}\text { Disturbance }+ \text { basin } \\
+ \text { ice }+ \text { temperature }+ \\
\text { wind }+ \text { sky }\end{array}$ & $\begin{array}{c}\text { Year + system + natural + } \\
\text { management + beaver + } \mathrm{LO}+ \\
\mathrm{OW}+\mathrm{DE}+\mathrm{BL}+\mathrm{FO}+\mathrm{HE}+ \\
\mathrm{PH}+\mathrm{CC}+\mathrm{WE}\end{array}$ & 640.65 & 20.95 & 1.00 \\
\hline \multirow[t]{6}{*}{ MALL } & Ice + disturbance & DE & 2074.52 & 0.00 & 1.00 \\
\hline & Disturbance + basin & System + Naturalness + & 2089.34 & 14.83 & 1.00 \\
\hline & + ice + temperature + & Management $+\mathrm{LO}+$ Beaver + & & & \\
\hline & wind + sky & $\mathrm{OW}+\mathrm{DE}+\mathrm{BL}+\mathrm{FO}+\mathrm{HE}+$ & & & \\
\hline & & $\mathrm{PH}+\mathrm{CC}+\mathrm{WE}$ & & & \\
\hline & Constant & Constant & 2128.0 & 53.49 & 1.00 \\
\hline
\end{tabular}


Table 3. List of N-mixture models used to determine the top model for black duck (ABDU) and mallard (MALL) abundances in November and March 2015-2016 and 2016-2017 in western Pennsylvania and north-central West Virginia, USA. Models include land ownership (LO), open water within $200 \mathrm{~m}(\mathrm{OW})$, developed land within $200 \mathrm{~m}$ (DE), barren land within $200 \mathrm{~m}$ (BL), forested land within $200 \mathrm{~m}$ (FO), herbaceous land within $200 \mathrm{~m}$ (HE), pasture/hay within $200 \mathrm{~m}$ (PH), cultivated crop land within $200 \mathrm{~m}$ (CC), and wetland within $200 \mathrm{~m}$ (WE).

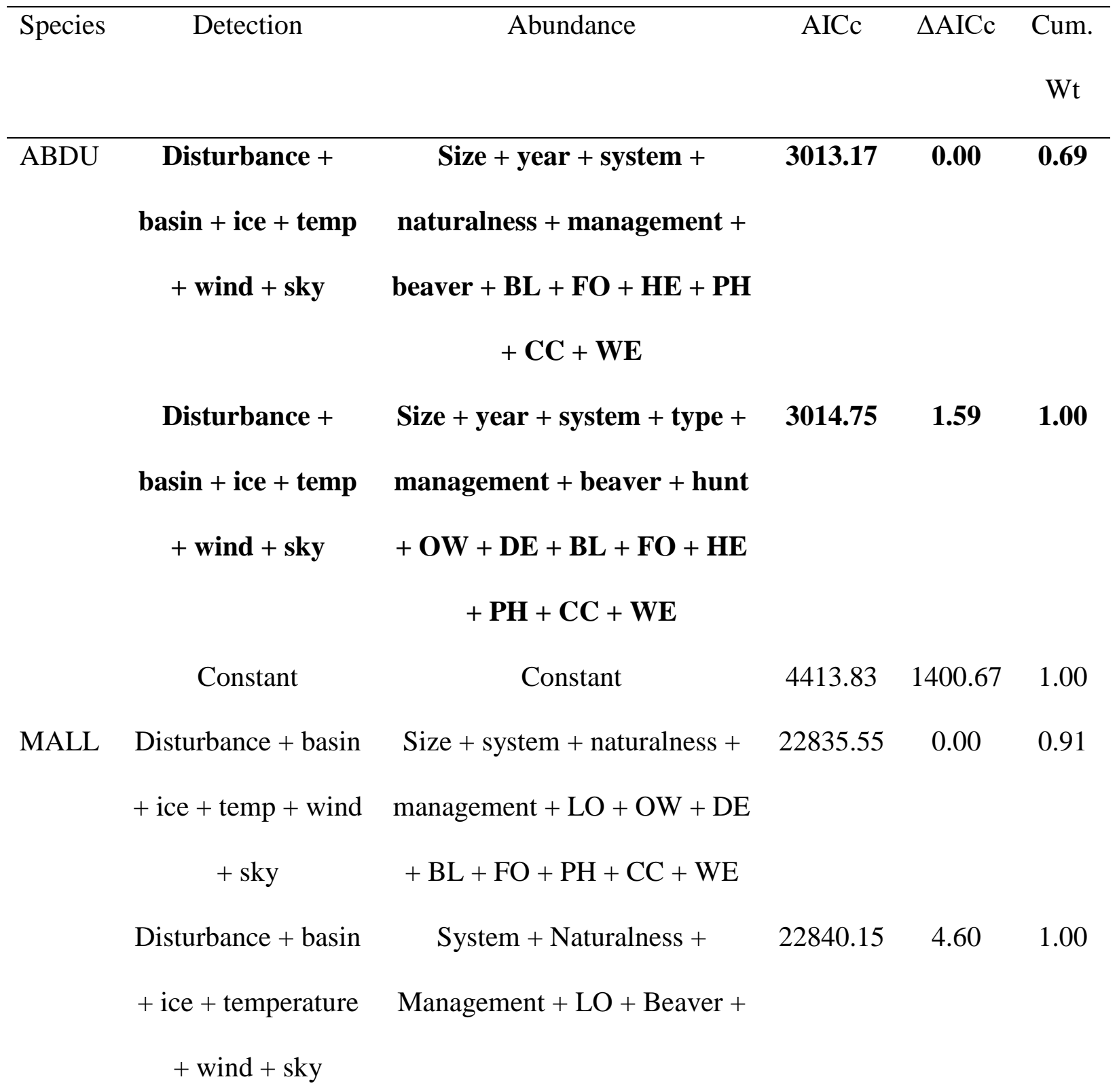




$$
\begin{gathered}
\mathrm{OW}+\mathrm{DE}+\mathrm{BL}+\mathrm{FO}+\mathrm{HE}+ \\
\mathrm{PH}+\mathrm{CC}+\mathrm{WE}
\end{gathered}
$$




\section{APPENDIX A. PUBLISHED TME VALUES OF BLACK DUCK FOODS}

List of invertebrate and seed items and respective true metabolizable energy (TME) values found in benthic core samples taken from wetlands in north-central West Virginia and western Pennsylvania in March - April and November - December 2017. If an item was considered a preferred food of American black ducks from published literature, it was included in biomass, energy, and duck use day estimates.

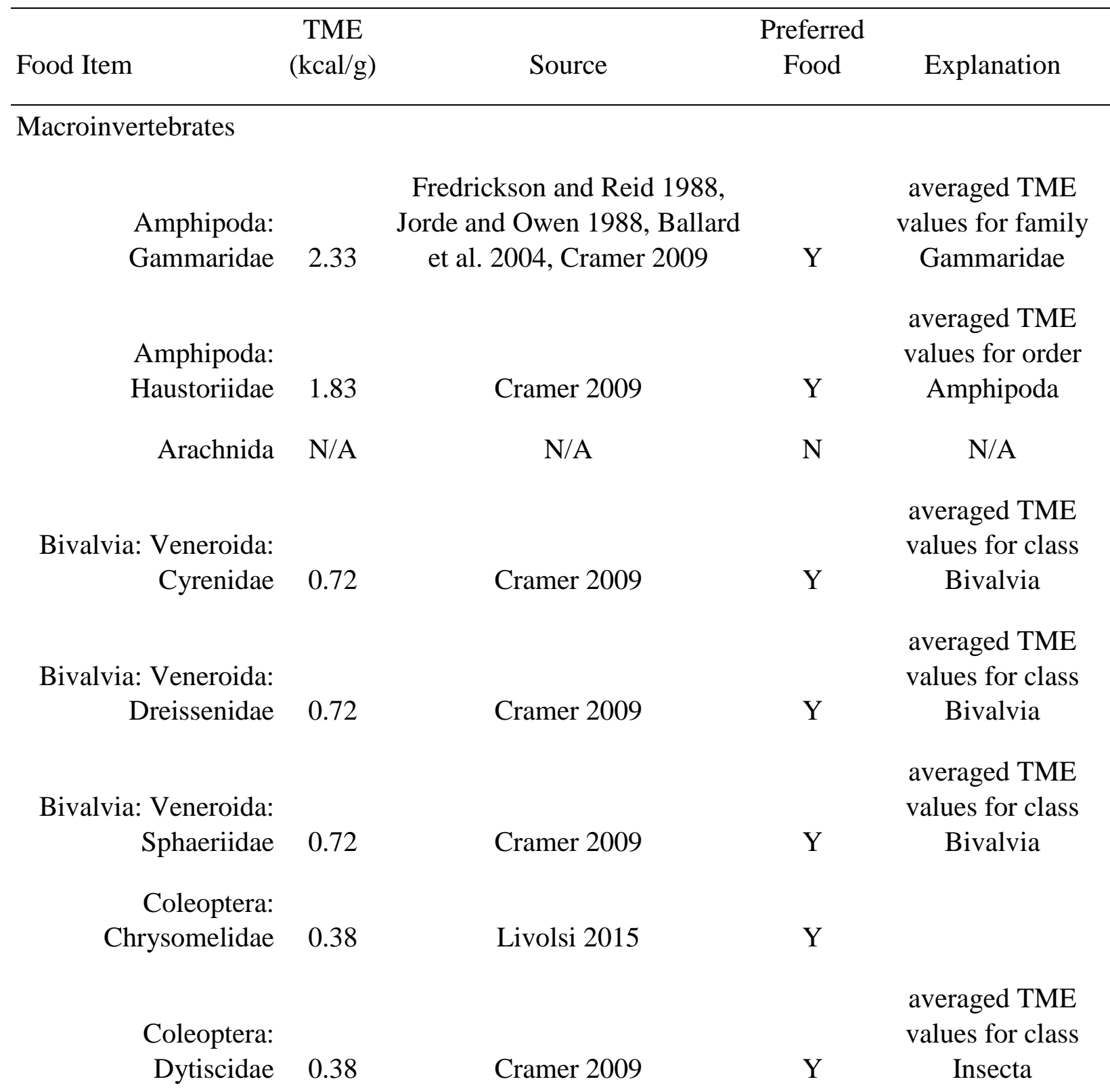


Coleoptera: Elmidae $\quad 0.38$

Coleoptera: Gyrinidae $\quad 0.38$

Coleoptera: Haliplidae 0.38

Coleoptera: Noteridae $\quad 0.38$

Collembola:

Poduridae N/A

Cramer 2009

Cramer 2009, Livolsi 2015

Y

Y

Y

averaged TME

values for class

Insecta

averaged TME

values for class

Insecta

averaged TME

values for class

Insecta

$\mathrm{N}$

N/A

TME value for

Sherfy 1999, Cramer 2009

Y

Isopoda
Y

TME value for

Gastropoda:

Hydrobiidae

0.77

Gastropoda:

Lymnaeidae $\quad 0.43$

Gastropoda:

Lymnaeidae:

Pseudosuccinea $\quad 0.43$

Gastropoda: Physidae $\quad 0.43$

Gastropoda: Physidae:

$$
\text { Physa } 0.43
$$

Gastropoda: Physidae:

$$
\text { Physella } 0.43
$$

Livolsi 2015

Cramer 2009

Cramer 2009

\author{
Cramer 2009
}

Cramer 2009

Y

Y

Hydrobiidae:

hydrobia spp.

averaged TME

values for class

Y

Gastropoda

averaged TME

values for class

Y

Gastropoda

averaged TME

values for class

Gastropoda

averaged TME

values for class

Gastropoda

averaged TME values for class

Cramer 2009

Gastropoda 
Gastropoda: Physidae:

Physella:

Heterostropha 0.43

Gastropoda: Physidae:

Physella: Vinosa

0.43

Cramer 2009

Gastropoda:

Planorbidae $\quad 0.43$

Gastropoda:

Valvatidae $\quad 0.43$

Hempitera:

Heteroptera:

Notonectidae $\quad 0.48$

Hemiptera: Gerridae N/A

Hirudinea:

Glossiphoniidae N/A

Hirudinea:

Hirudinidae N/A

Insecta: Diptera

0.27

Sherfy 1999, Cramer 2009

Sherfy 1999, Cramer 2009, Livolsi 2015

N/A

N/A

$\mathrm{N}$

N/A

$\mathrm{N}$

Y

Insecta: Diptera:

Ceratopogonidae

0.38

Cramer 2009

Y

Insecta: Diptera:

Chironomidae:

Chironomus

0.27

Sherfy 1999, Cramer 2009

Insecta: Diptera:

Chironomidae

Insecta: Diptera:

Muscidae

Livolsi 2015 averaged TME

values for class

Gastropoda

averaged TME

values for class

Gastropoda

averaged TME

values for class

Gastropoda

averaged TME

values for class

Gastropoda

TME value for

Hemiptera

Corixidae

N/A

N/A

N/A

TME value for family Diptera

averaged TME values for class

Insecta

TME value for family Diptera

TME value for family Diptera

TME value for family Diptera 
Insecta: Diptera:

Tabinidae

Insecta:

Ephemeroptera:

Baetidae 0.38

Isopoda: Asellidae $\quad 0.08$

Nematoda N/A

Odonata:

Calopterygidae N/A

Odonata: Libellulidae N/A

Oligochaeta: Naididae N/A

Seeds

Adoxaceae: Sambucus N/A

Alismataceae:

Sagittaria 3.06

Amaranthaceae:

Amaranthus 2.97

Amaranthaceae:

Chenopodium 2.52

Asteraceae: Ambrosia N/A

Asteraceae: Bidens aristosa

0.55

Asteraceae:

Helianthus N/A

Asteraceae:

Hieriacium N/A

Asteraceae:

Taraxacum N/A
Livolsi 2015

Cramer 2009

Cramer 2009

N/A

N/A

N/A

N/A

N/A

$\mathrm{N}$

N/A

Y Isopoda

N/A

N/A

N/A

N/A

Insecta

$\mathrm{N}$

Hoffman and Brookhout 1985, Cramer 2009

Y

Checkett et al. 2002, Cramer

2009

$\mathrm{Y}$

Dugger et al. 2007, Cramer

2009

Y

N/A

$\mathrm{N}$

N/A

Mendall 1949, Sherfy 1999,

Cramer 2009

published TME of

Y

Bidens cernua

\section{averaged TME}

value for order

averaged TME

ue for class

TME value for 


\begin{tabular}{|c|c|c|c|c|}
\hline Betulaceae: Betula & N/A & N/A & $\mathrm{N}$ & N/A \\
\hline \multicolumn{5}{|l|}{$\begin{array}{r}\text { Betulaceae: Ostrya } \\
\text { virginiana }\end{array}$} \\
\hline & & & & $\begin{array}{c}\text { published TME } \\
\text { value of }\end{array}$ \\
\hline Brassicaceae: & & Dugger et al. 2007, Cramer & & Brassicaceae: \\
\hline Lepidium & 1.31 & 2009 & Y & Lepidium latifolium \\
\hline Cannabaceae: Celtis & N/A & N/A & $\mathrm{N}$ & N/A \\
\hline Cyperaceae: Carex & 1 & Livolsi 2015 & $\mathrm{Y}$ & \\
\hline & & & & $\begin{array}{c}\text { average of } \\
\text { published seed }\end{array}$ \\
\hline Cornaceae: Cornus & 1.96 & Mendall 1949, Cramer 2009 & $\mathrm{Y}$ & TME values \\
\hline \multirow[b]{2}{*}{ Cyperaceae: Cyperus } & & $\begin{array}{c}\text { McGilvrey 1966, Sherfy } 1999, \\
\text { Ballard et al. 2004, Livolsi }\end{array}$ & & average of Cyperus \\
\hline & 1.42 & 2015 & $\mathrm{Y}$ & $s p p$. values \\
\hline \multirow[b]{2}{*}{ Cyperaceae: Scirpus } & 0.5 & $\begin{array}{l}\text { Dugger et al. 2007, Cramer } \\
\text { 2009, Livolsi } 2015\end{array}$ & $\mathrm{Y}$ & \\
\hline & 0.82 & Livolsi 2015 & $\mathrm{Y}$ & $\begin{array}{c}\text { published TME } \\
\text { value of } \\
\text { Cyperaceae: } \\
\text { Schoenoplectus spp. }\end{array}$ \\
\hline \multicolumn{5}{|l|}{ Euphorbaceae: } \\
\hline Euphorbia & N/A & N/A & $\mathrm{N}$ & N/A \\
\hline Fabaceae: Desmodium & N/A & N/A & $\mathrm{N}$ & N/A \\
\hline Fabaceae: Medicago & N/A & N/A & $\mathrm{N}$ & N/A \\
\hline $\begin{array}{r}\text { Fabaceae: Robinia } \\
\text { pseudoacacia }\end{array}$ & N/A & N/A & $\mathrm{N}$ & N/A \\
\hline $\begin{array}{r}\text { Fagaceae: Fagus } \\
\text { grandifolia }\end{array}$ & N/A & N/A & $\mathrm{N}$ & N/A \\
\hline Fagaceae: Quercus & 2.76 & $\begin{array}{l}\text { Hartman 1963, Kaminski et al. } \\
2003\end{array}$ & Y & \\
\hline
\end{tabular}


Haloragaceae:

Myriophllum

N/A

N/A

$\mathrm{N}$

N/A

Hamamelidaceae:

Hamamelis N/A

N/A

$\mathrm{N}$

N/A

Hydrocharitaceae:

Anacharis

N/A

N/A

$\mathrm{N}$

N/A

Hydrocharitaceae:

Elodea N/A

N/A

$\mathrm{N}$

N/A

Hydrocharitaceae:

Hydrilla N/A

N/A

N/A

average of

Hydrocharitaceae:

Najas 1.96 Mendall 1949, Cramer 2009

Y

published seed

Najas
Juglandaceae: Carya
Juncaceae: Juncus
Lauraceae: Lindera
Malvaceae: Tilia
americana
Nymphaaeceae:

Nuphar

N/A

N/A

TME values

N/A

1.21 Cramer 2009, Livolsi $2015 \quad$ Y

N/A

N/A

$\mathrm{N}$

N/A

N/A

N/A

$\mathrm{N}$

N/A

average of published seed

TME values

average of

Nymphaeaceae:

Nymphaea

1.96

Mendall 1949, Cramer 2009

Y

published seed

Oleaceae: Fraxinus N/A

N/A

$\mathrm{N}$

N/A

Platanaceae: Platanus occidentalis N/A

N/A

$\mathrm{N}$

N/A

Poaceae: Agrostis N/A

N/A

$\mathrm{N}$

N/A

Poaceae: Arthraxon N/A

N/A

$\mathrm{N}$

N/A

Poaceae: Echinochloa N/A

N/A

$\mathrm{N}$

N/A 


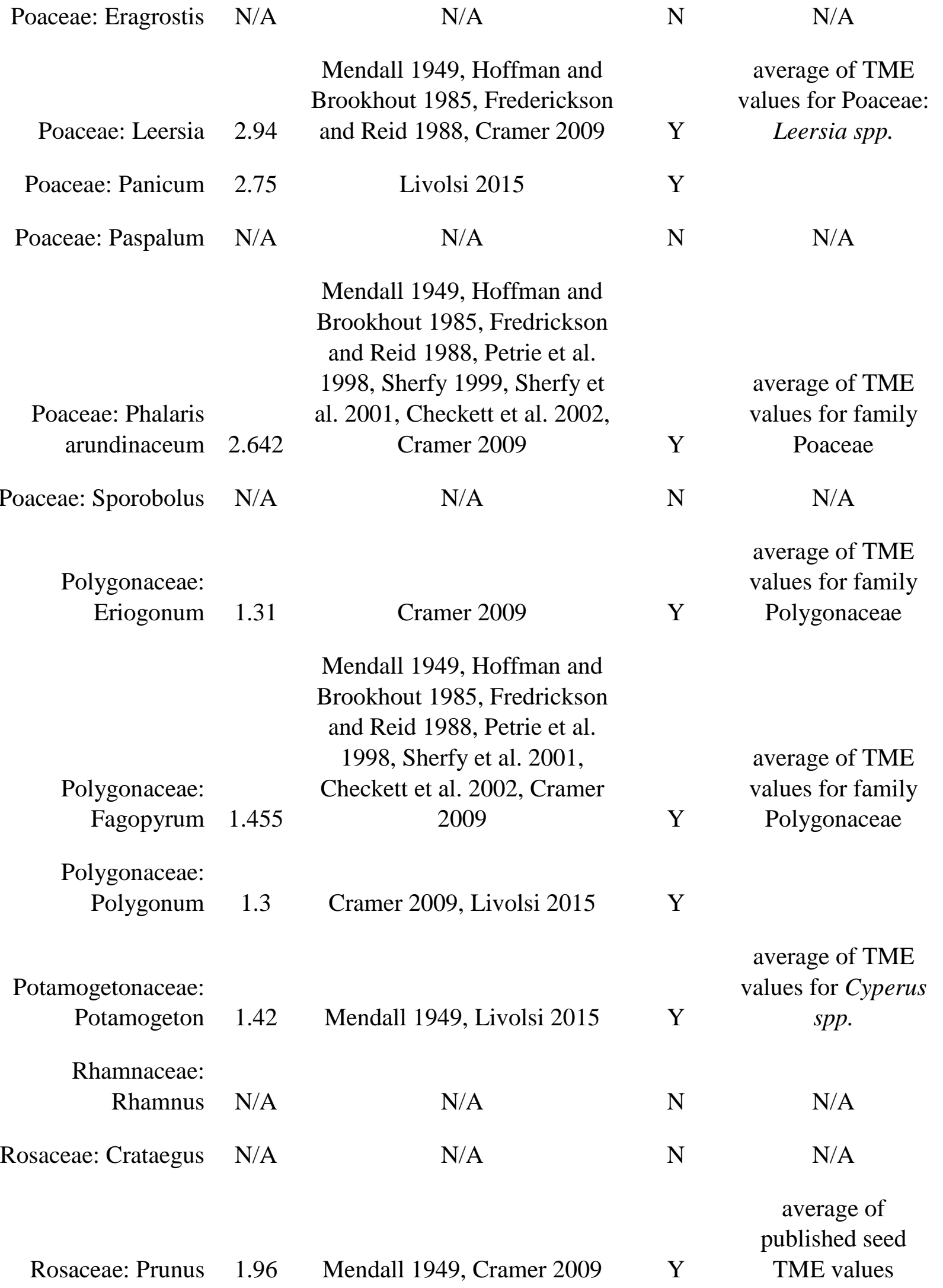




\begin{tabular}{ccccc} 
Rosaceae: Rubus & 1.96 & Mendall 1949, Cramer 2009 & Y & $\begin{array}{c}\text { average of } \\
\text { published seed } \\
\text { TME values }\end{array}$ \\
$\begin{array}{r}\text { Rubiaceae: } \\
\text { Cephalanthus }\end{array}$ & 1.96 & McGilvrey 1966, Cramer 2009 & Y & \\
$\begin{array}{r}\text { Sapindaceae: Acer } \\
\text { N/A }\end{array}$ & N/A & N & N/A \\
$\begin{array}{c}\text { Typhaceae: } \\
\text { Sparganium }\end{array}$ & 1.96 & $\begin{array}{c}\text { Reinecke and Owen 1980, } \\
\text { Hoffman 1983, Mendall 1949 }\end{array}$ & Y & $\begin{array}{c}\text { Published seed } \\
\text { TME values }\end{array}$ \\
\hline
\end{tabular}




\section{APPENDIX B. UNIVARIATE MODELS}

Univariate models used to compare wetland biomass from both benthic core samples and moistsoil seed production sampling among different wetland systems, management schemes, levels of wetland naturalness, and seasons.

\begin{tabular}{lcc}
\hline \multicolumn{1}{c}{ Univariate General Linear Models } & Lower 95\% CI & Upper 95\% CI \\
\hline Benthic core biomass Wetland system & 474.76 & $1,108.19$ \\
Benthic core biomass Level of naturalness & 158.99 & $1,100.74$ \\
Benthic core biomass Management scheme & 396.64 & $1,208.43$ \\
Benthic seed biomass Wetland system & 133.72 & 247.38 \\
Benthic seed biomass Level of naturalness & 147.80 & 371.37 \\
Benthic seed biomass Management scheme & 134.77 & 239.54 \\
Benthic macroinvertebrate biomass Wetland system & 279.73 & 917.18 \\
Benthic macroinvertebrate biomass Level of naturalness & -91.10 & 897.25 \\
Benthic macroinvertebrate biomass Management scheme & 176.32 & 998.75 \\
Moist-soil seed biomass Wetland system & 20.0 & 588.91 \\
Moist-soil seed biomass Level of naturalness & 260.71 & 590.01 \\
Moist-soil seed biomass Management scheme & 212.47 & 553.86 \\
\hline
\end{tabular}




\section{APPENDIX C. SYSTEM-ASSOCIATED MOIST-SOIL SEED BIOMASS ESTIMATIONS}

Seed biomass ( $\mathrm{kg} / \mathrm{ha}$ ) estimates of wintering American black duck foods across wetland systems from moist-soil seed production sampling performed between August and October 2017 in western Pennsylvania and north-central West Virginia.

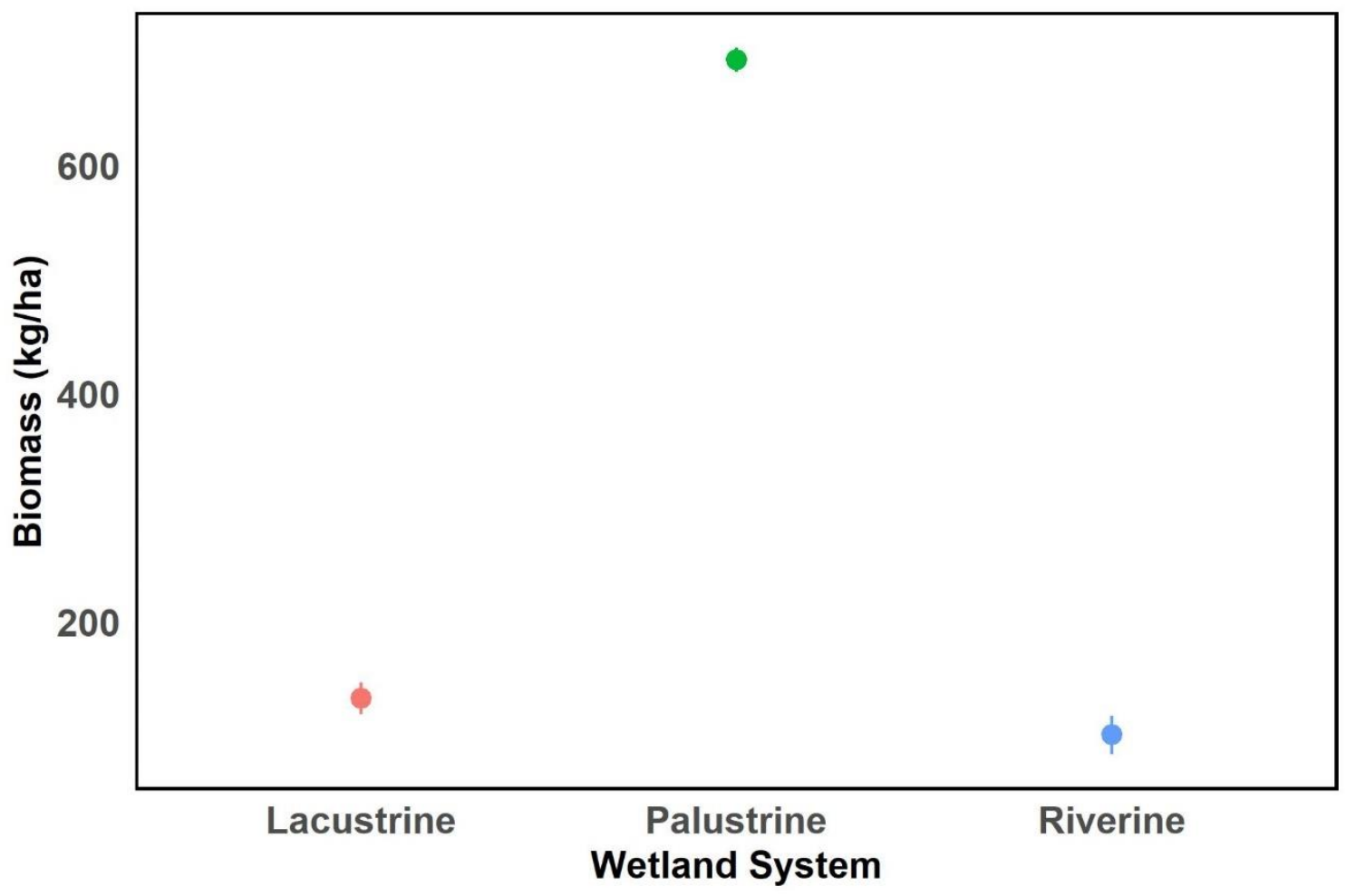




\section{APPENDIX D. LEVEL OF NATURALNESS-ASSOCIATED MOIST-SOIL SEED BIOMASS ESTIMATIONS.}

Seed biomass ( $\mathrm{kg} / \mathrm{ha})$ estimates of wintering American black duck foods across levels of wetland naturalness from moist-soil seed production sampling performed between August and October 2017 in western Pennsylvania and north-central West Virginia.

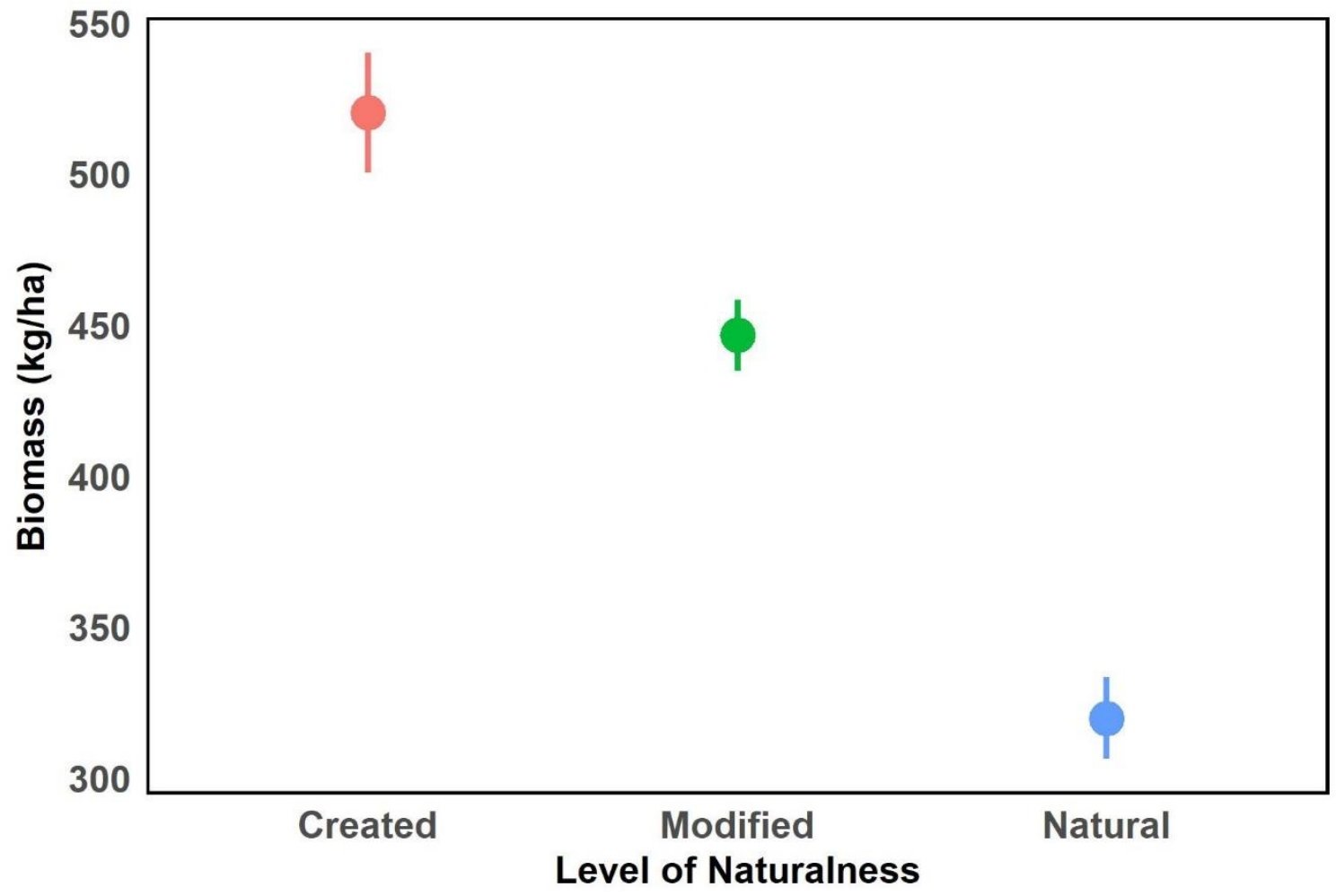




\section{APPENDIX E. MANAGEMENT SCHEME-ASSOCIATED MOIST-SOIL SEED BIOMASS ESTIMATIONS}

Seed biomass ( $\mathrm{kg} / \mathrm{ha})$ estimates of wintering American black duck foods across wetland management schemes from moist-soil seed production sampling performed between August and October 2017 in western Pennsylvania and north-central West Virginia.

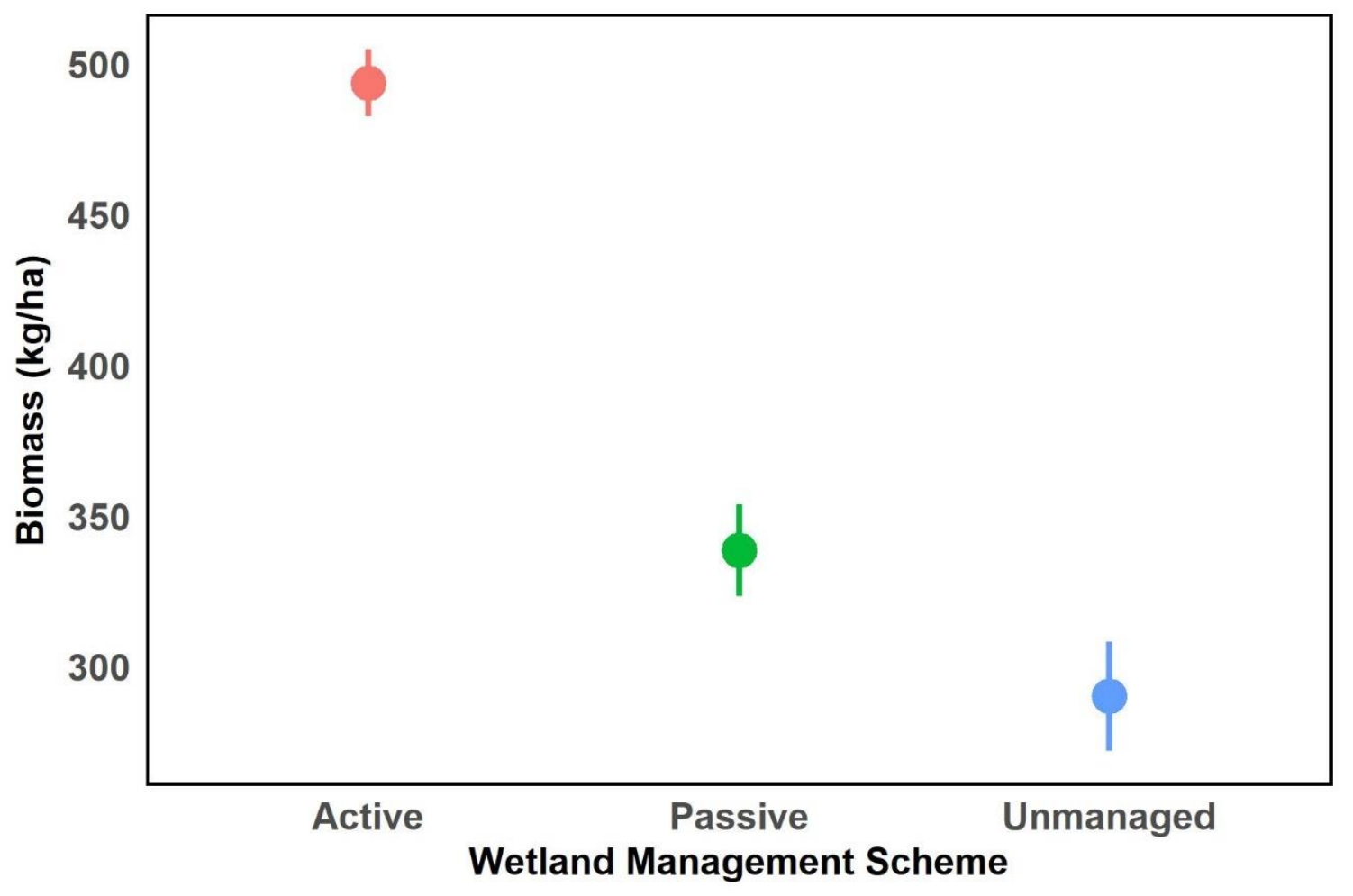




\section{APPENDIX F. SYSTEM-ASSOCIATED BENTHIC CORE BIOMASS ESTIMATIONS}

Combined seed and macroinvertebrate biomass ( $\mathrm{kg} / \mathrm{ha})$ estimates of wintering American black duck foods across wetland systems from benthic core sampling performed between March-April and November-December 2017 in western Pennsylvania and north-central West Virginia.

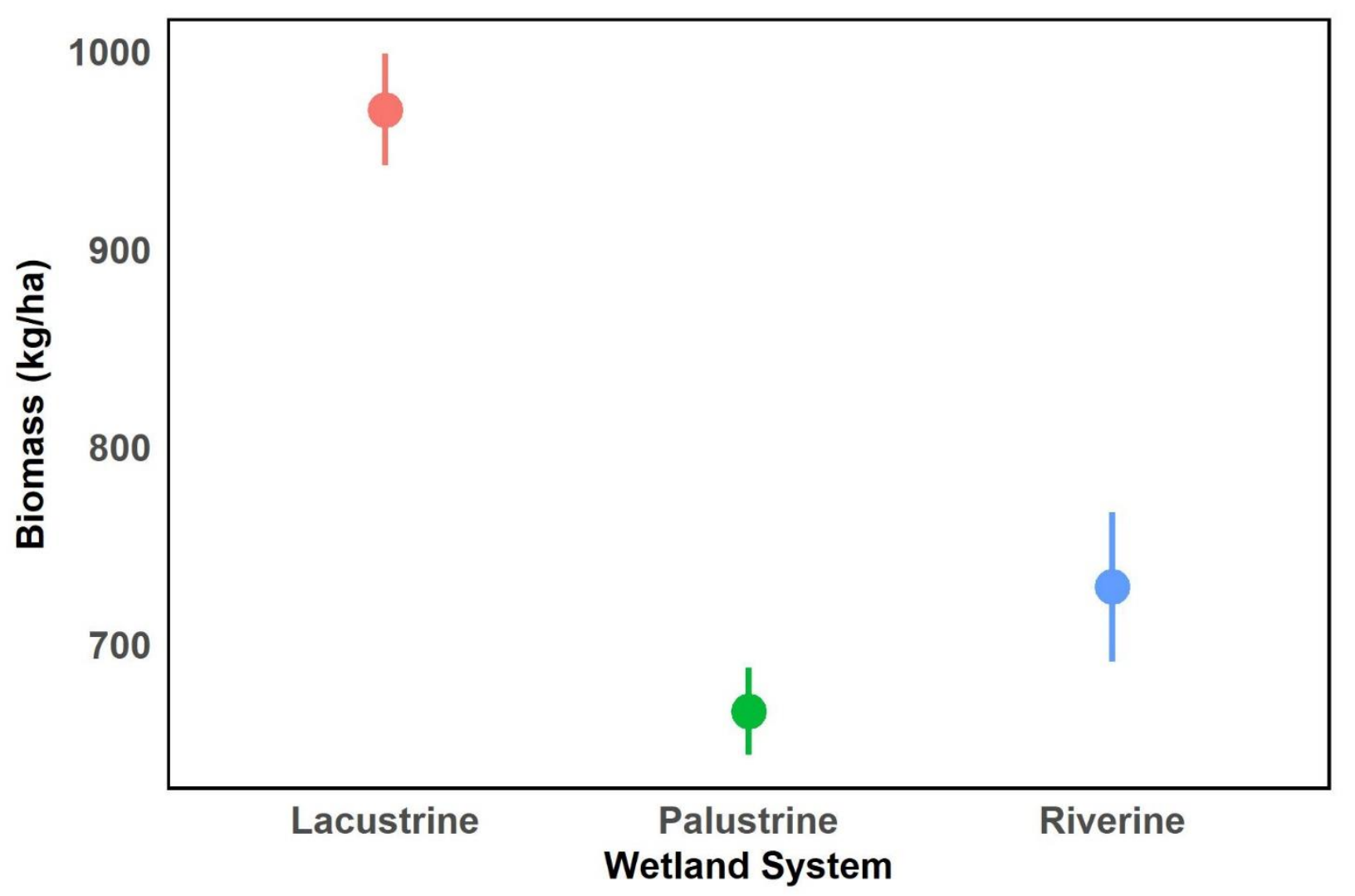




\section{APPENDIX G. LEVEL OF NATURALNESS-ASSOCIATED BENTHIC CORE BIOMASS ESTIMATIONS}

Combined seed and macroinvertebrate biomass $(\mathrm{kg} / \mathrm{ha})$ estimates of wintering American black duck foods across levels of wetland naturalness from benthic core sampling performed between March-April and November-December 2017 in western Pennsylvania and north-central West Virginia.

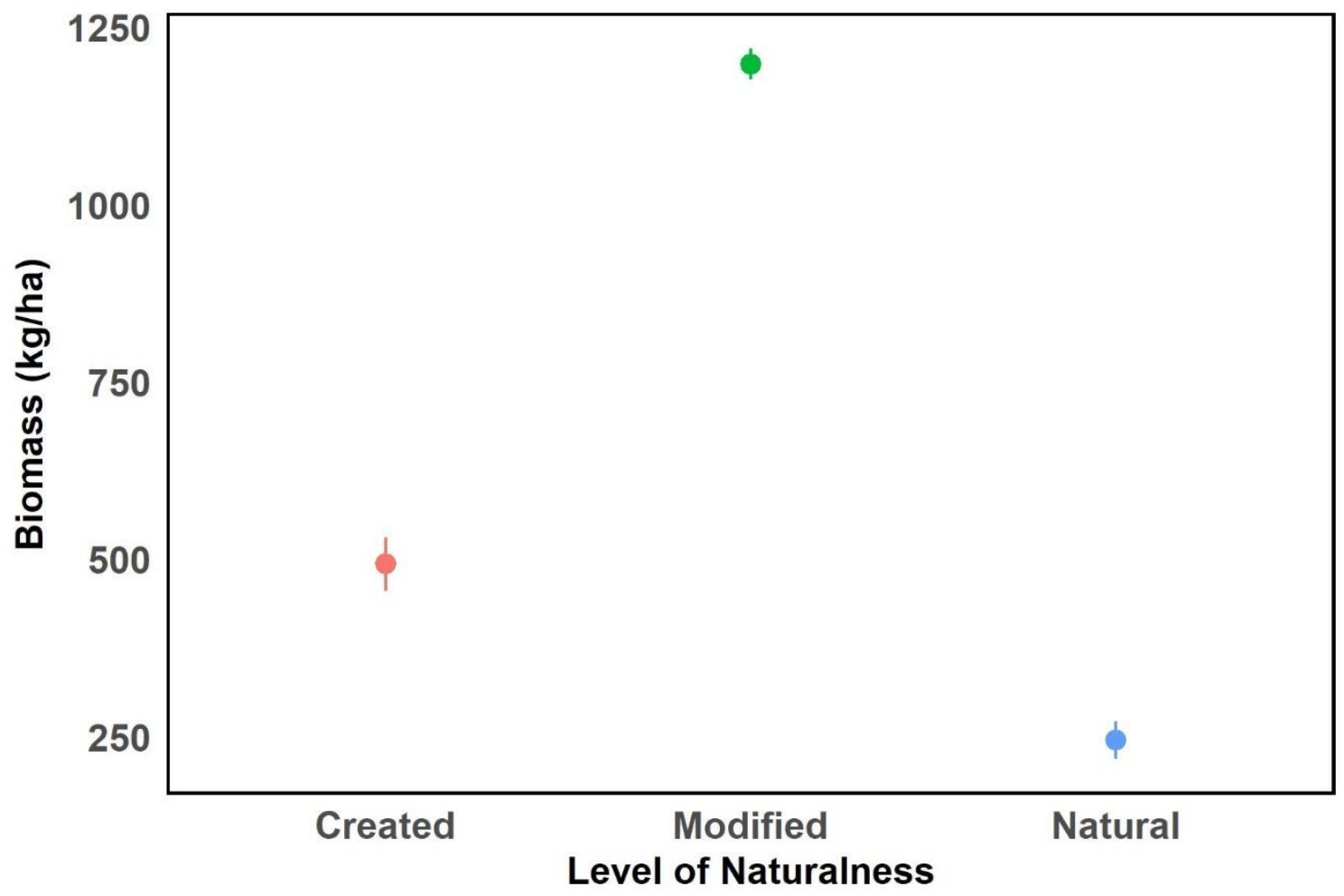




\section{APPENDIX H. MANAGEMENT SCHEME-ASSOCIATED BENTHIC CORE BIOMASS ESTIMATIONS}

Combined seed and macroinvertebrate biomass ( $\mathrm{kg} / \mathrm{ha}$ ) estimates of wintering American black duck foods across wetland management schemes from benthic core sampling performed between March-April and November-December 2017 in western Pennsylvania and north-central West Virginia.

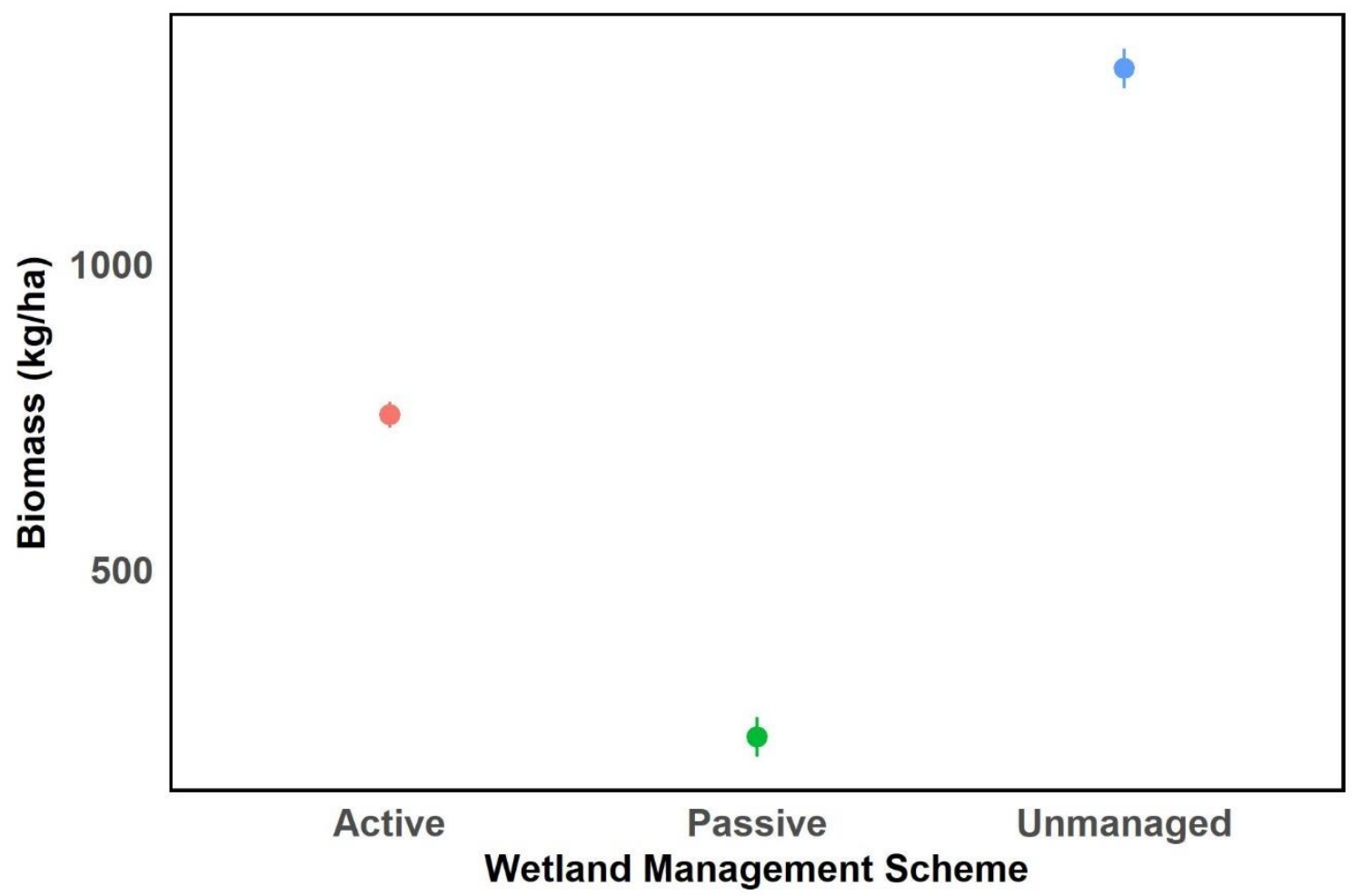




\section{APPENDIX I. AVERAGE MONTHLY TEMPERATURES}

Average monthly temperature during wintering waterbird surveys across all study sites in northcentral West Virginia and western Pennsylvania between November - March of 2015 2016 and $2016-2017$ (NCEI 2017).

Average monthly temperature of study years

\begin{tabular}{lcc}
\hline & $2015-2016$ & \\
\cline { 2 - 2 } Month & $\bar{x}\left({ }^{\circ} \mathrm{C}\right)$ & $\bar{x}\left({ }^{\circ} \mathrm{C}\right)$ \\
\hline November & 8.71 & 6.98 \\
December & 7.01 & 0.51 \\
January & -3.18 & 1.68 \\
February & 0.64 & 4.18 \\
March & 7.62 & 9.59 \\
Total study period & 4.15 & 4.72 \\
\hline
\end{tabular}




\section{APPENDIX J. ACTIVITY-SPECIFIC MULTIPLIERS}

Activity-specific multipliers $\left(a_{i}\right)$ used in energy expenditure calculations of non-breeding American black ducks in western Pennsylvania and north-central West Virginia in November -

March of 2015 - 2016 and 2016 - 2017.

\begin{tabular}{|c|c|c|}
\hline Behavior & $\begin{array}{c}\text { Multiple } \\
\text { of RMR } \\
\left(a_{i}\right)\end{array}$ & Source \\
\hline Foraging & 1.7 & Wooley 1976, Livolsi 2015 \\
\hline Sleeping & 1.2 & Wooley 1976, Livolsi 2015 \\
\hline Resting & 1.2 & Wooley 1976, Livolsi 2015 \\
\hline Comfort-movements & 2.1 & Wooley 1976, Livolsi 2015 \\
\hline Swimming & 2.2 & Wooley 1976, Wooley and Owen 1978, Livolsi 2015 \\
\hline Disturbance-induced/alert & 2.2 & Wooley 1976, Livolsi 2015 \\
\hline Flying & 12.5 & Wooley 1976, Wooley and Owen 1978, Livolsi 2015 \\
\hline Agonistic & 2.4 & Wooley 1976, Livolsi 2015 \\
\hline Courtship & 2.4 & Wooley 1976, Livolsi 2015 \\
\hline Self-maintenance & 1.6 & Wooley and Owen 1978 \\
\hline
\end{tabular}




\section{APPENDIX K. WETLAND SYSTEM-ASSOCIATED BEHAVIORAL PROPORTIONS}

Behavioral proportions of across wetland systems from time activity budgets of wintering

American black ducks in western Pennsylvania and north-central West Virginia, November -

March 2015 - 2016 and 2016 - 2017.
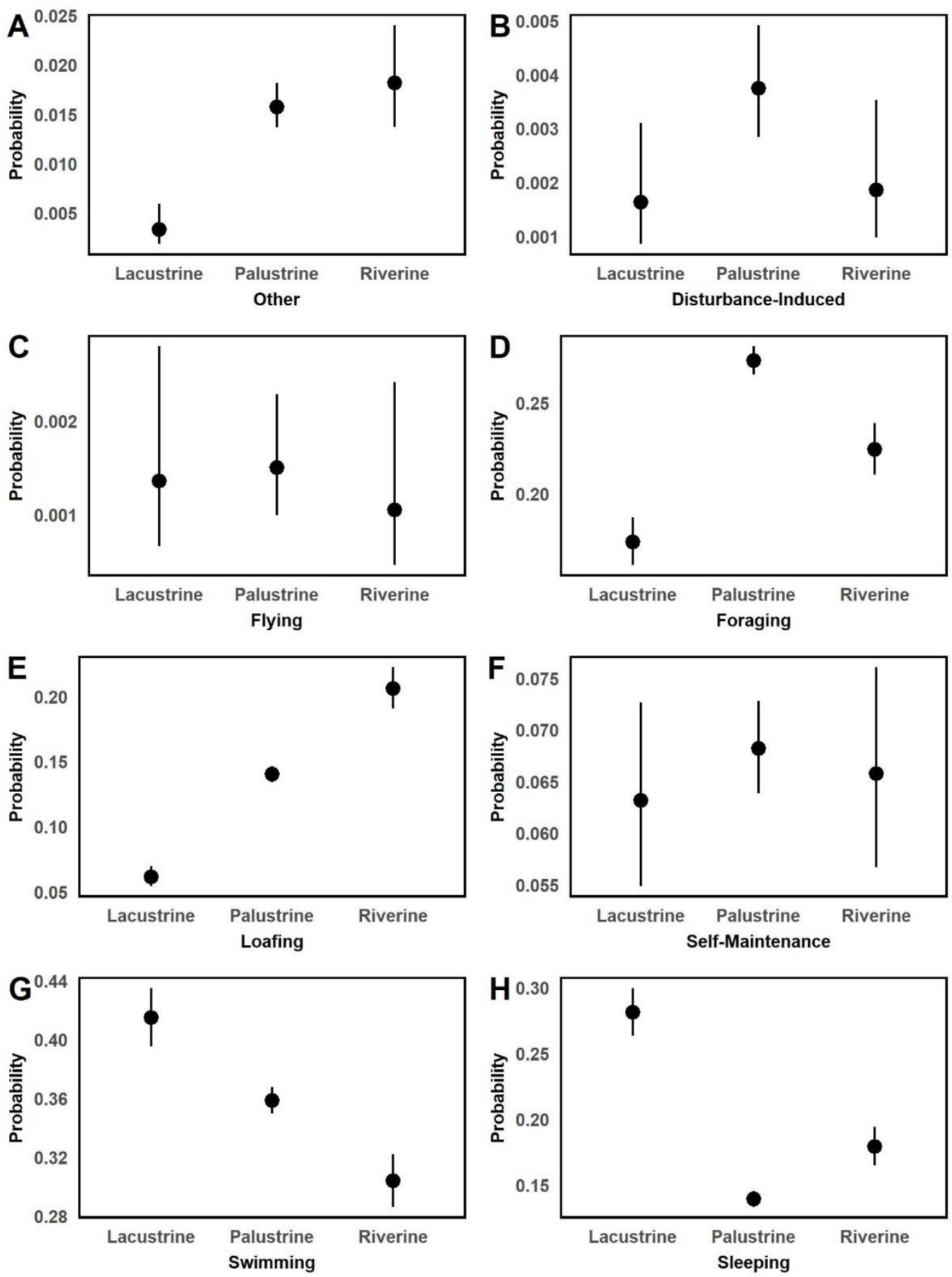


\section{APPENDIX L. LEVEL OF NATURALNESS-ASSOCIATED BEHAVIORAL PROPORTIONS}

Behavioral proportions of across levels of wetland naturalness from time activity budgets of wintering American black ducks in western Pennsylvania and north-central West Virginia, November - March 2015 - 2016 and 2016 - 2017.
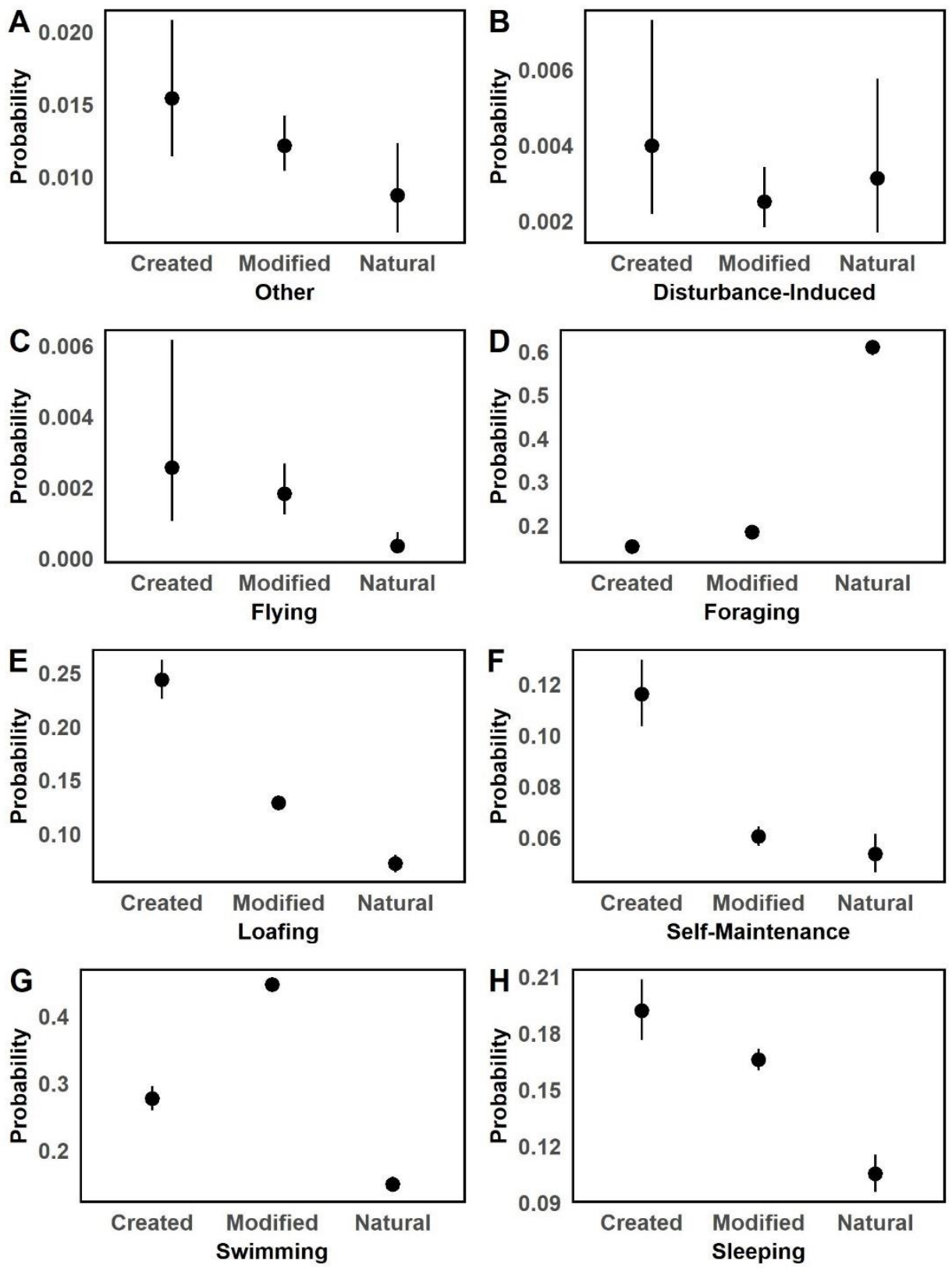


\section{APPENDIX M. WETLAND MANAGEMENT SCHEME-ASSOCIATED BEHAVIORAL PROPORTIONS}

Behavioral proportions of across wetland management from time activity budgets of wintering American black ducks in western Pennsylvania and north-central West Virginia, November March 2015 - 2016 and 2016 - 2017.
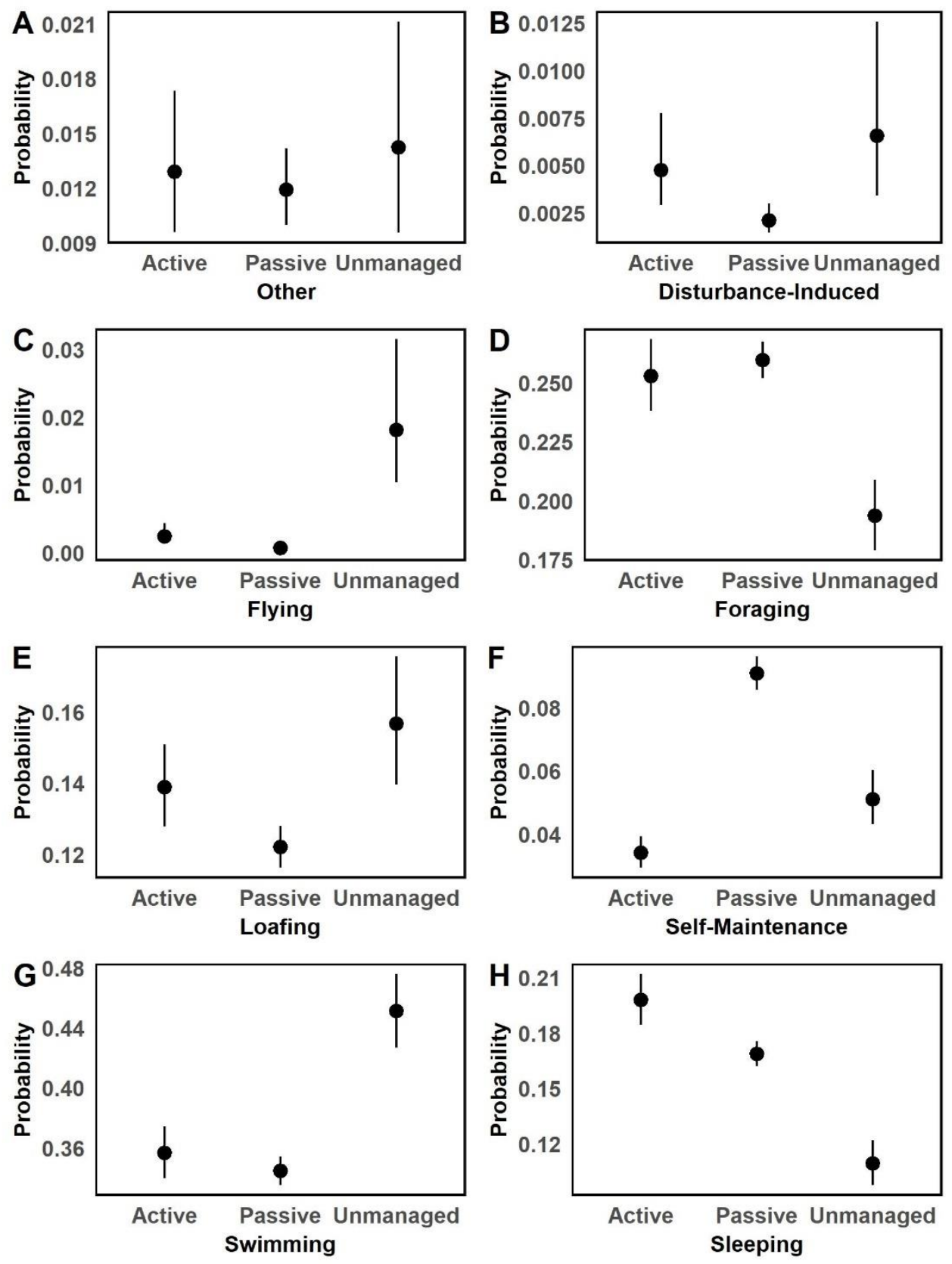


\section{APPENDIX N. YEAR-ASSOCIATED BEHAVIORAL PROPORTIONS}

Behavioral proportions across years from time activity budgets of wintering American black

ducks in western Pennsylvania and north-central West Virginia, November - March 2015 - 2016 and $2016-2017$.
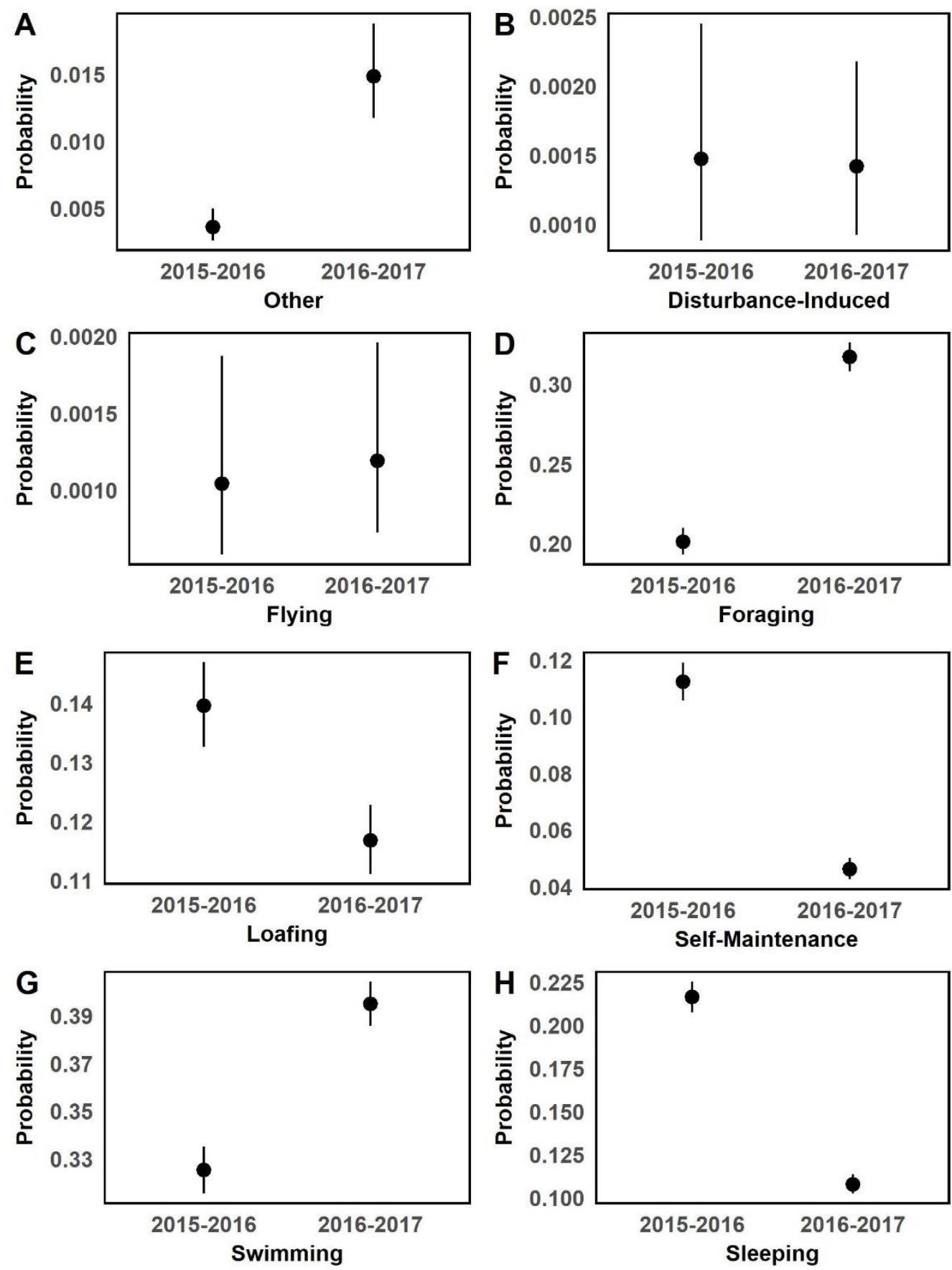


\section{APPENDIX O. DAILY ENERGY EXPENDITURE VALUES OF AMERICAN BLACK DUCKS}

Our study and previously reported daily energy expenditure (DEE) values of American black ducks. SCT stands for simple cost of thermoregulation model, CCT stands for complex cost of thermoregulation model, and ADR stands for allometrically derived RMR (Miller and Eadie 2006).

\begin{tabular}{|c|c|c|c|c|c|}
\hline Paper & Location & $\begin{array}{c}\text { DEE } \\
\text { (kJ/bird/ } \\
\text { day) }\end{array}$ & $\begin{array}{c}12 \text { or } 24 \mathrm{hr} \\
\text { behavioral } \\
\text { observations }\end{array}$ & Method & Model type \\
\hline This study & $\begin{array}{c}\text { PA and WV, } \\
\text { USA }\end{array}$ & 684.94 & 12 & $\begin{array}{c}\text { Time energy } \\
\text { budget }\end{array}$ & SCT \\
\hline This study & $\begin{array}{c}\text { PA and WV, } \\
\text { USA }\end{array}$ & $1,542.95$ & 12 & $\begin{array}{c}\text { Time energy } \\
\text { budget }\end{array}$ & $\mathrm{CCT}$ \\
\hline Jones et al. 2014 & NJ, USA & $1,349.01$ & 12 & $\begin{array}{c}\text { Time energy } \\
\text { budget }\end{array}$ & SCT \\
\hline Jones et al. 2014 & NJ, USA & $1,218.08$ & 24 & $\begin{array}{c}\text { Time energy } \\
\text { budget }\end{array}$ & SCT \\
\hline Jones et al. 2014 & NJ, USA & $1,244.25$ & N/A & $\begin{array}{c}\text { Average of RMR } \\
\text { values }\end{array}$ & $\begin{array}{c}\text { Black duck } \\
\text { specific RMR }\end{array}$ \\
\hline Cramer 2009 & NJ, USA & $1,187.30$ & 12 & $\begin{array}{c}\text { Time energy } \\
\text { budget }\end{array}$ & $\begin{array}{c}\text { Fixed CT } \\
\text { model }\end{array}$ \\
\hline Livolsi 2015 & DE, USA & $1,418.04$ & 24 & $\begin{array}{c}\text { Time energy } \\
\text { budget }\end{array}$ & CCT \\
\hline $\begin{array}{l}\text { Livolsi et al. } \\
2015 a\end{array}$ & NJ, USA & $1,077.17$ & 24 & $\begin{array}{c}\text { Time energy } \\
\text { budget }\end{array}$ & SCT \\
\hline $\begin{array}{l}\text { Livolsi et al. } \\
2015 a\end{array}$ & NJ, USA & $1,176.05$ & 24 & $\begin{array}{c}\text { Time energy } \\
\text { budget }\end{array}$ & $\mathrm{CCT}$ \\
\hline $\begin{array}{l}\text { Albright et al. } \\
1983\end{array}$ & ME, USA & $\begin{array}{l}665.42- \\
1,000.22\end{array}$ & 12 & $\begin{array}{c}\text { Time energy } \\
\text { budget }\end{array}$ & SCT \\
\hline Hickey 1980 & PE, CA & $\begin{array}{c}887.22- \\
929.07\end{array}$ & 12 & $\begin{array}{c}\text { Time energy } \\
\text { budget }\end{array}$ & SCT \\
\hline
\end{tabular}




\section{APPENDIX P. DAILY ENERGY EXPENDITURE VALUES WITH OTHER RMR}

\section{VALUES}

Daily energy expenditure (DEE) values incorporating both simple and complex cost of thermoregulation models obtained using time activity budgets from this study and an RMR value from Cramer (2009) and Jones (2012) incorporating averaged masses from captured black ducks in New Jersey. We also calculated an allometrically derived DEE following methods from Miller and Eadie (2006) including the RMR value used in this study (Jones 2012).

\begin{tabular}{lcccc}
\hline Source of RMR & RMR & $\begin{array}{c}\text { 12 or 24 hr } \\
\text { behavioral } \\
\text { observations }\end{array}$ & Method & $\begin{array}{c}\text { DEE } \\
\text { (kJ/bird/day) }\end{array}$ \\
\hline Cramer 2009, Jones 2012 & 514.98 & 12 & Simple CT model & 669.30 \\
Cramer 2009, Jones 2012 & 514.98 & 12 & Complex CT model & $1,524.36$ \\
\hline
\end{tabular}




\section{APPENDIX Q. WIND SPEED CODES}

Beaufort Scale wind speed codes ( $\mathrm{mph}$ and $\mathrm{Kph}$ ) used during wintering waterfowl and black duck surveys between November and March 2015-2016 and 2016-2017 in western Pennsylvania and north-central West Virginia, USA.

\begin{tabular}{ll}
\hline Beaufort scale & Wind speed indicators
\end{tabular}

0

Smoke rises vertically $(<1 \mathrm{mph},<2 \mathrm{Kph})$.

Wind direction shown by smoke drift (1-3

mph, 2-5 Kph).

2

Wind felt on face; leaves rustle (4-7 mph, 6-

$12 \mathrm{Kph})$.

3

Leaves, small twigs in constant motion (8-12

mph, 13-19 Kph).

4

Dust rises; small branches move (13-18 mph, 20-29 Kph).

Small trees in leaf begin to sway (19-24 mph, 30-38 Kph). 


\section{APPENDIX R. SKY CONDITION CODES}

Weather Bureau sky condition indicator codes used during wintering waterfowl and black duck surveys between November and March 2015-2016 and 2016-2017 in western Pennsylvania and north-central West Virginia, USA.

\begin{tabular}{lc}
\hline Weather bureau code & Sky condition indicators \\
\hline 0 & Clear or few clouds \\
1 & Partly cloudy (scattered) or variable sky \\
2 & Cloudy (broken) or overcast \\
4 & Fog or smoke \\
5 & Drizzle \\
7 & Snow \\
8 & Showers \\
\hline
\end{tabular}

